DIAGENESIS AND BURIAL HISTORY OF THE LOWER CRETACEOUS TRAVIS PEAK FORMATION. EAST TEXAS

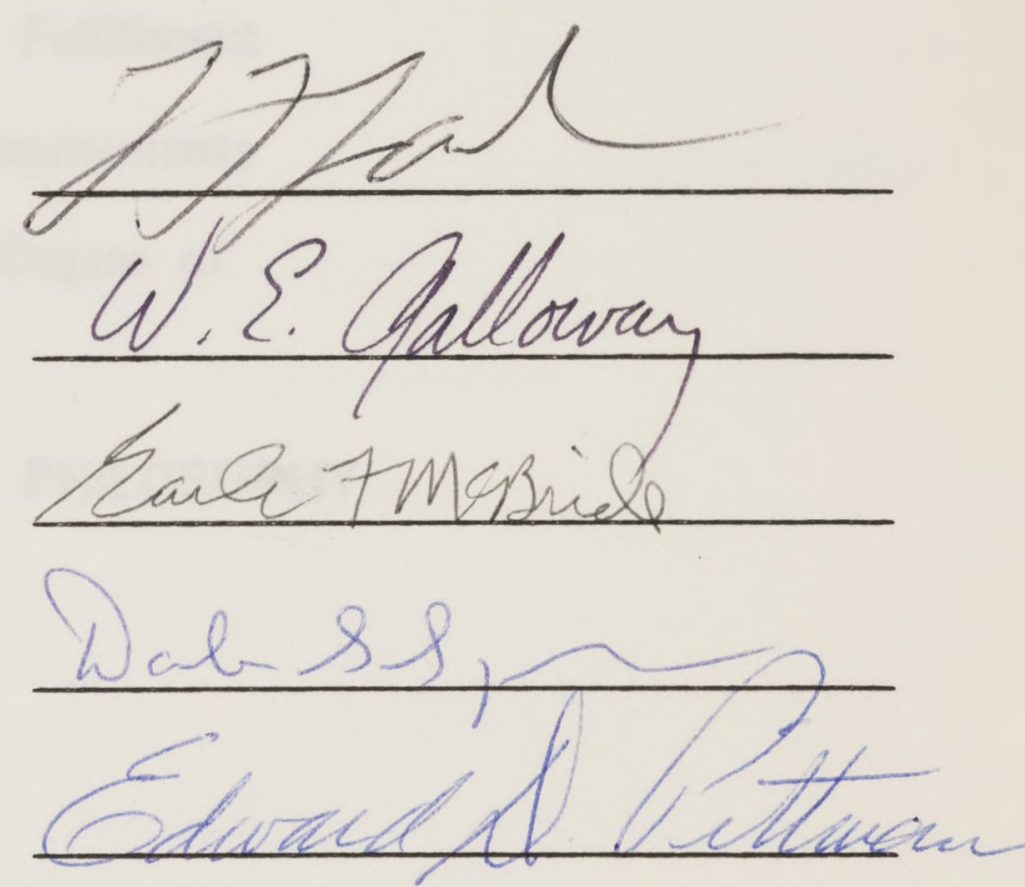


DIAGENESIS AND BURIAL HISTORY OF THE LOWER CRETACEOUS TRAVIS PEAK FORMATION. EAST TEXAS

by

SHIRLEY PETERSON DUTTON, B.A., M.A.

\author{
DISSERTATION \\ Presented to the Faculty of the Graduate School of \\ The University of Texas at Austin \\ in Partial Fulfillment \\ of the Requirements \\ for the Degree of \\ DOCTOR OF PHILOSOPHY
} THE UNIVERSITY OF TEXAS AT AUSTIN December, 1986 
Copyright

by

Shirley Peterson Dutton

1986 


\section{ACKNOWLEDGMENTS}

Funding for this dissertation research was provided by the Gas Research Institute as part of Contract No. 5082-211-0708 with the Bureau of Economic Geology. The University of Texas at Austin, entitled "Geologic Analysis of Primary and Secondary Tight Gas Sand Objectives", Robert J. Finley. Principal Investigator. I appreciate receiving the permission and support of the Bureau of Economic Geology to conduct the dissertation research as part of a Bureau of Economic Geology project.

The cooperation of the following companies and operators is gratefully acknowledged: Amoco Production Company (USA), ARCO Oil and Gas Company. Arkla Exploration Company. Ashland Exploration, Inc., Delta Drilling Company. Marshall Exploration. Inc.. Prairie Producing Company. Reynolds Drilling Company, Inc., Stallworth Oil and Gas, Inc., Sun Oil Company, and Clayton W. Williams, Jr.

Lynton S. Land supervised this dissertation and performed the isotopic analyses. I greatly appreciate the generous contribution of his time in performing these analyses and all the other research assistance he has offered. His scientific abilities and his insights into the problems of diagenesis have challenged me in this and other projects. Earle $\mathrm{F}$. McBride, William E. Galloway, Dale S. Sawyer, and Edward D. Pittman served on the dissertation committee. The dissertation has benefited from their geologic experience and editoral suggestions. Dale Sawyer provided 
geophysical data and contributed significantly to my understanding of heat flow and paleotemperatures.

I have benefited greatly from instruction, research assistance, and thoughtful discussions with the following people: Patricia Bobeck. Alan Dutton, Robert Finley, Stephen Fisher. Michael Fracasso, Missy Jackson. Tim Jackson. Stephen Laubach. Long-Cheng Liang, Kitty Milliken, Prasanta Mukhopadhyay. Alice Spencer, Amy Wilkerson, John Wilson, and James Wittke. Larry Mack performed the strontium isotopic analyses. Dianne Pavlicek did a thorough job as student editor that improved the dissertation. 


\title{
DIAGENESIS AND BURIAL HISTORY OF THE LOWER CRETACEOUS TRAVIS PEAK FORMATION. EAST TEXAS
}

\author{
Publication No. \\ Shirley Peterson Dutton, Ph.D. \\ The University of Texas at Austin. 1986
}

Supervising Professor: Lynton S. Land

Sandstone in the Travis Peak (Hosston) Formation has been extensively modified by burial diagenesis. Permeability in much of the formation has been reduced to less than $0.1 \mathrm{md}$ as a result of compaction. extensive precipitation of authigenic minerals, and minor pressure solution. Thin zones of higher porosity and permeability occur mainly near the top of the formation; porosity and permeability decrease with depth below the top. The Travis Peak Formation in East Texas is approximately $2,000 \mathrm{ft}$ $(600 \mathrm{~m})$ thick; depth to the top of the formation ranges from $5.800 \mathrm{ft}$ $(1.770 \mathrm{~m})$ to $9.400 \mathrm{ft}(2,870 \mathrm{~m})$.

Travis Peak sandstone is fine- to very fine-grained quartzarenite and subarkose having an average composition of $\mathrm{Q}_{95} \mathrm{~F}_{4} \mathrm{R}_{1}$. Plagioclase feldspar is more abundant than orthoclase, and chert and low-rank metamorphic rock fragments are the most common lithic components. 
The first authigenic cement to precipitate was illite, which coated detrital grains with tangentially oriented crystals. Next, extensive quartz cement, averaging $17 \%$ of the rock volume in well-sorted sandstone. occluded much of the primary porosity. Quartz cement is most abundant in the lower Travis Peak, in well-connected sandstone beds that were deposited in braided streams. Oxygen-isotopic composition of quartz overgrowths indicates that they precipitated from meteoric fluids at temperatures of $130^{\circ}$ to $165^{\circ} \mathrm{F}\left(55^{\circ}\right.$ to $\left.75^{\circ} \mathrm{C}\right)$. These temperatures equate to depths of 3.000 to $5.000 \mathrm{ft}$ (900 to $1.500 \mathrm{~m})$.

Dissolution of orthoclase and albitization of plagioclase followed quartz cementation and occurred prior to mid-Cretaceous movement of the Sabine Uplift. An abrupt loss of orthoclase occurs at $1.200 \mathrm{ft}(365 \mathrm{~m})$ below the top of the Travis Peak. and albitization is more extensive deeper in the formation. Illite (a second generation), chlorite, and ankerite precipitated after feldspar diagenesis; these late authigenic phases incorporate ferrous iron released by thermal reduction of iron compounds. Ankerite was derived primarily from early dolomite cement, but it incorporated some light carbon from maturation of organic matter and radiogenic strontium from feldspar dissolution. The oxygen-isotopic composition of pore fluids evolved during ankerite precipitation from -4 o/oo to +3 o/oo (SMOW): $+3 \% / 00$ is the present composition of Travis Peak water.

Oil migrated into Travis Peak reservoirs about 65 mya from shale in 
the Bossier Formation. Later deasphalting of the oil filled much of the remaining porosity in some zones near the top of the formation with reservoir bitumen. 


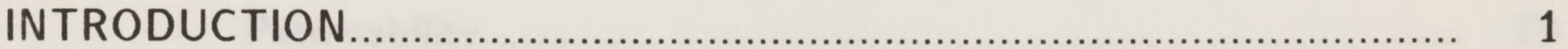

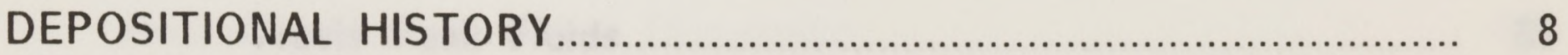

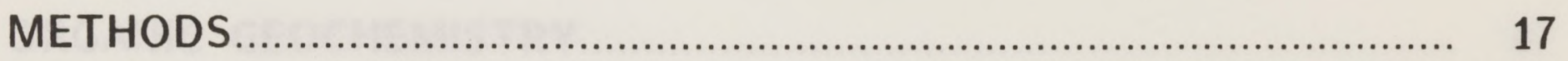

TRAVIS PEAK COMPOSITION.......................................................... 19

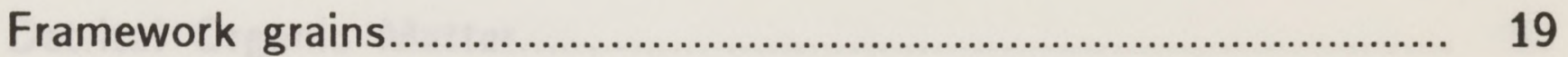

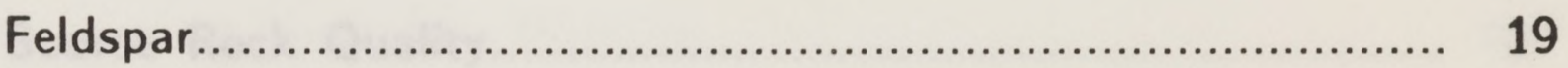

Plagioclase ............................................................. 23

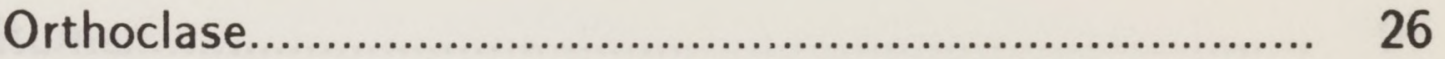

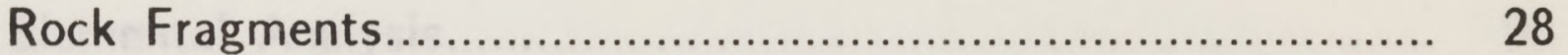

Nonessential Constituents............................................. 29

Provenance....................................................................... 30

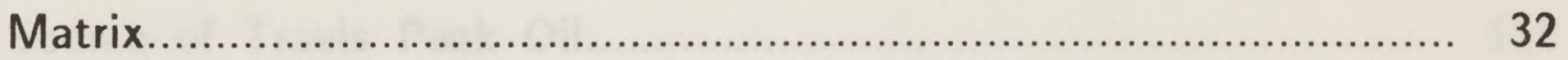

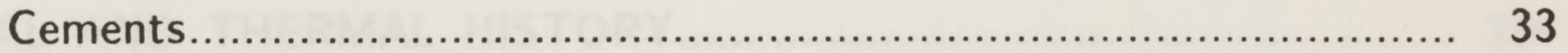

Authigenic Quartz.................................................. 35

Authigenic Clay Minerals........................................... 46

Authigenic Carbonate Cements.................................... 52

Major element composition.................................. 54

Isotopic composition............................................ 58

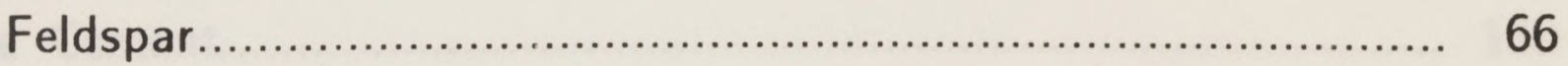


Other Authigenic Minerals............................................... 66

Solid Hydrocarbons...................................................... 67

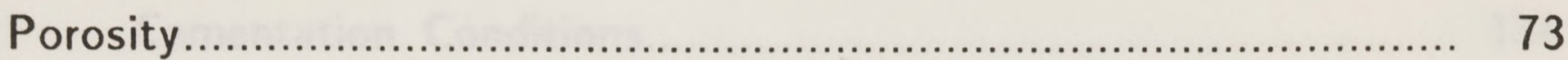

Pre-cement Porosity....................................................... 78

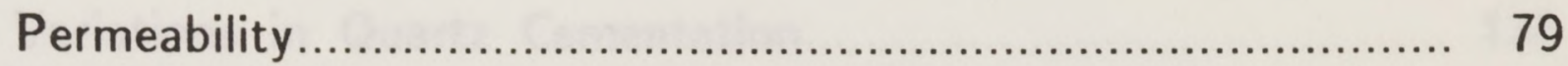

Travis Peak Fluids......................................................... 85

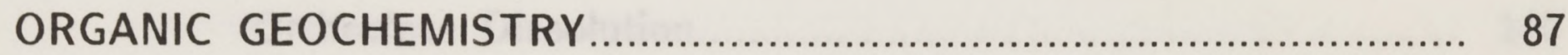

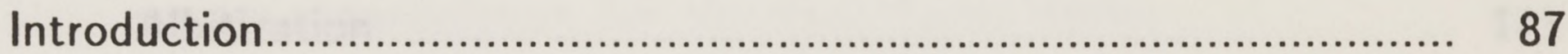

Detrital Organic Matter........................................................... 87

Source Rock Quality.................................................. 87

Thermal Maturity ......................................................... 91

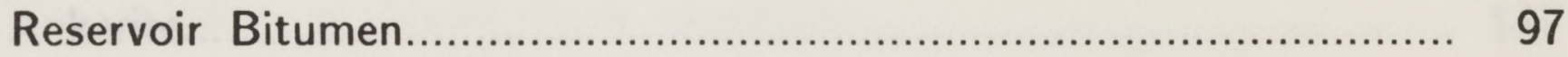

Elemental Analysis.................................................. 98

Chromatography........................................................ 101

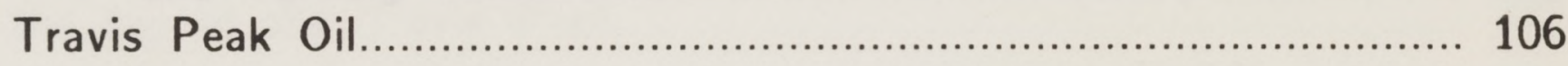

Source of Travis Peak Oil..................................................... 111

BURIAL AND THERMAL HISTORY ........................................... 114

Burial-History Curves........................................................ 114

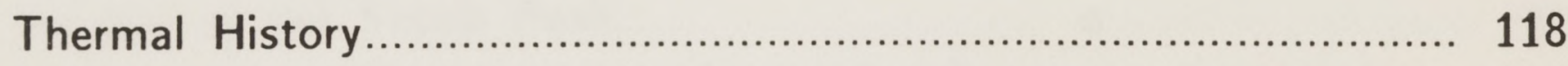

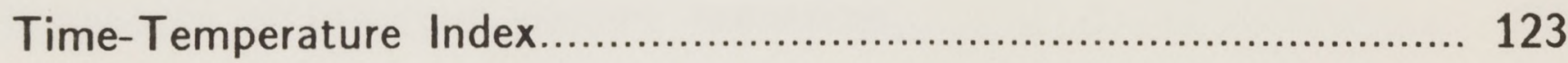

INTERPRETATION OF DIAGENETIC HISTORY ............................. 129

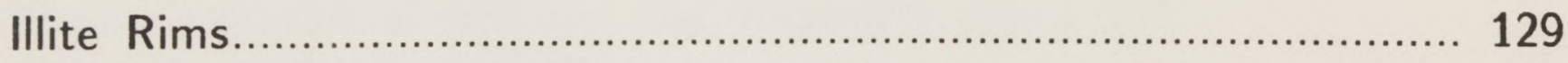

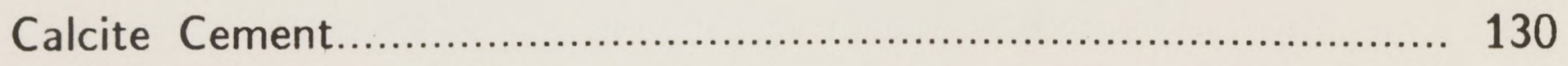




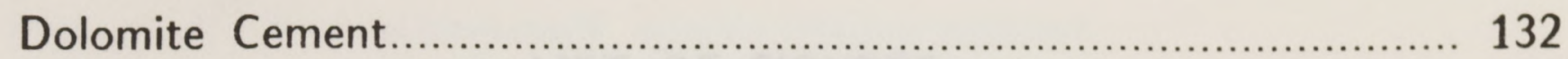

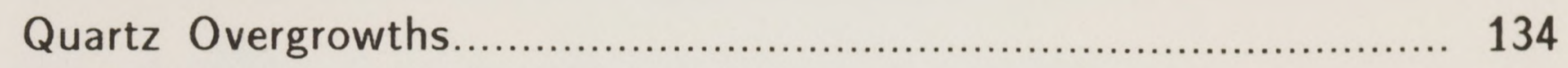

Cementation Conditions.................................................. 134

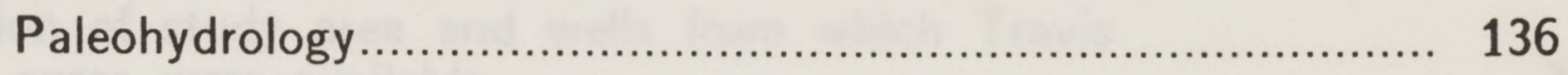

Variations in Quartz Cementation...................................... 138

Feldspar Albitization and Dissolution......................................... 140

Orthoclase Dissolution..................................................... 140

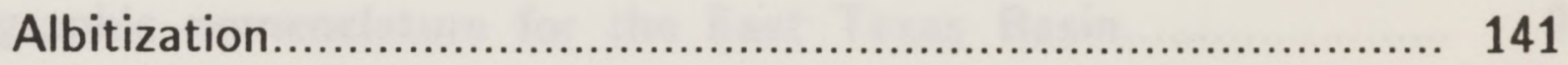

Feldspar Distribution.................................................. 142

Development of Secondary Porosity .......................................... 143

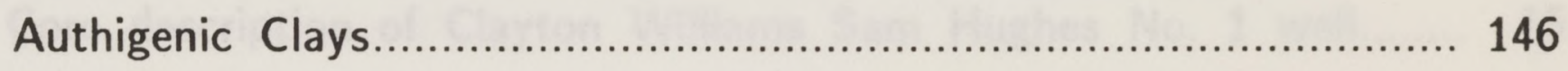

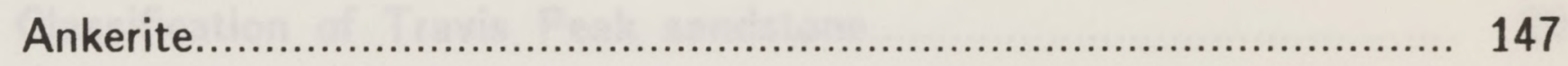

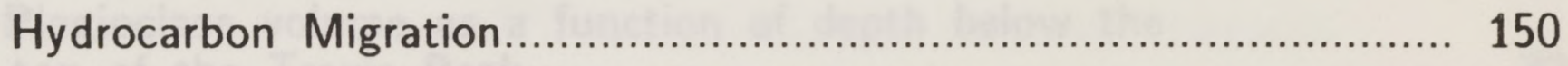

Comparison with Diagenesis in other Gulf Coast Mesozoic and Tertiary Sandstones.............................................. 152

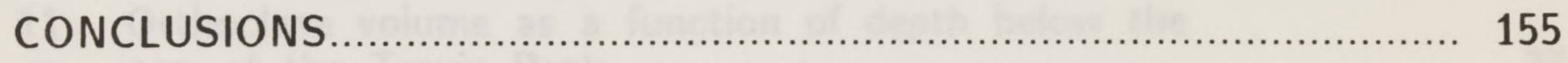

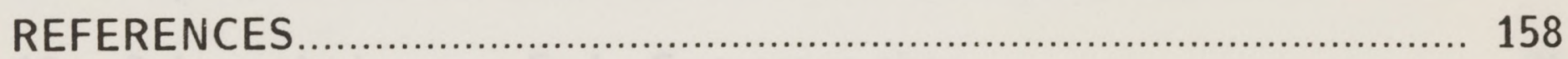




\section{LIST OF FIGURES}

$\underline{\text { Figure }}$

page

1. Location of study area and wells from which Travis

Peak cores were available.

2. Regional tectonic map of the central Gulf Coast Province.............. 3

3. Core control plotted against depth below the top of the

Travis Peak.

4. Stratigraphic nomenclature for the East Texas Basin.................... 9

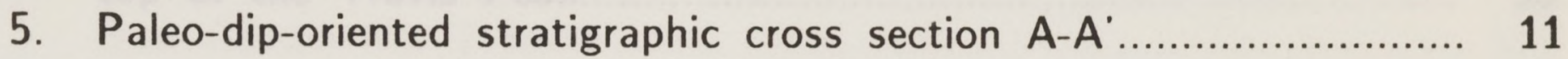

6. Core description of Prairie Mast No. 1-A well.............................. 12

7. Core description of Clayton Williams Sam Hughes No. 1 well....... 15

8. Classification of Travis Peak sandstone...................................... 20

9. Plagioclase volume as a function of depth below the top of the Travis Peak........................................................ 22

10. Plagioclase composition as a function of depth below the top of the Travis Peak.................................................... 25

11. Orthoclase volume as a function of depth below the top of the Travis Peak............................................................ 27

12. Paleogeologic map. Early Cretaceous time................................... 31

13. Relation between total volume of cement and depth below the top of the Travis Peak.

14. Frequency of observed cement sequences.................................... 36

15. Photomicrograph of quartzarenite............................................ 37

16. Photomicrograph of primary and secondary pores and euhedral quartz overgrowths 
17. Plot of $\delta^{18} \mathrm{O}$ of whole-rock quartz versus percent quartz overgrowths of total quartz.

18. Plot of $\delta^{18} \mathrm{O}$ of whole-rock quartz versus percent quartz overgrowths of total quartz in a) samples deeper in the formation and b) samples from the upper part of the formation.

19. SEM photograph of authigenic illite fibers and albite.................. 47

20. SEM photograph of thick illite cutans........................................ 49

21. SEM photograph of authigenic chlorite ........................................ 51

22. Dolomite cement volumes decreases with depth below the top of the Travis Peak............................................................... 53

23. Backscatter electron image of dolomite and ankerite cement.......... 55

24. Ankerite cement volume decreases with depth below the top of the Travis Peak.

25. Chemical composition of carbonate cements.

26. Plot of $\delta^{13} \mathrm{C}$ versus $\delta^{18} \mathrm{O}$ composition of carbonate cements........ 60

27. Reservoir bitumen volume decreases with depth below the top of the Travis Peak.

28. Photomicrograph of reservoir bitumen in primary porosity.

29. Rippled sandstone with reservoir bitumen highlighting ripple faces.

30. Primary porosity decreases with depth below the top of the Travis Peak.

31. Secondary porosity decreases with depth below the top of the Travis Peak.

32. Porosimeter porosity decreases with depth below the top of the Travis Peak.

33. Inverse relationship between quartz cement volume and unstressed permeability in matrix-free sandstones 
34. Inverse relationship between total cement volume and unstressed permeability in matrix-free sandstones.

35. Permeability decreases with depth in the Travis Peak.................. 84

36. Organic matter types classified by hydrogen and oxygen indices.

37. Gas chromatograms of $\mathrm{C}_{15+}$ saturate fraction of hydrocarbons extracted from reservoir bitumen.

38. Gas chromatograms of Travis Peak oil from Chapel Hill field. Smith County.

39. Burial history curves for the Ashland S.F.O.T. No. 1 and Sun Caudle No. 2 wells

40. Burial-history curve for the Ashland S.F.O.T. No. 1 well, showing interpreted times at which major diagenetic events occurred.

41. Locus of possible water temperatures and $\delta^{18} \mathrm{O}$ compositions for authigenic quartz, ankerite, and dolomite. 


\section{LIST OF TABLES}

\section{Table page}

1. Travis Peak cores used in this study ........................................... 6

2. Isotopic analyses of quartz ....................................................... 41

3. Isotopic analyses of carbonate cement....................................... 61

4. Strontium isotopic analyses...................................................... 65

5. Composition of Travis Peak water, in parts per million................ 86

6. Values of weight percent total organic carbon, relative amounts of the major kerogen types, and average vitrinite reflectance for Travis Peak shale samples........................ 89

7. Results of total organic carbon analyses and pyrolysis.................. 94

8. Elemental analysis data of reservoir bitumen extracted from Travis Peak sandstones................................................ 99

9. Geochemical analyses of extractable fraction of reservoir bitumen from Travis Peak sandstones..................................... 101

10. Geochemical analyses of Travis Peak crude oil........................... 108

11. Calculated time-temperature indices (TTI) and corresponding vitrinite reflectance values. 


\section{INTRODUCTION}

The Travis Peak is a sand-rich Lower Cretaceous formation deposited from 140 to 115 mya (Berriasian to Barremian time) in East Texas; it is equivalent to the Hosston Formation of Louisiana, Arkansas, and Mississippi. The purpose of this study was to determine the diagenetic history of Travis Peak sandstones in a six-county study area on the western flank of the Sabine Uplift (figs. 1, 2). In particular, the goals of the study were as follows: 1) to identify and quantify the detrital and authigenic phases in the formation, noting stratigraphic or geographic variations: 2) to interpret the chemical and hydrologic conditions under which each authigenic phase precipitated; and 3) to integrate the diagenetic history of Travis Peak sandstones with the burial and thermal history of the formation. including organic maturation and hydrocarbon migration. In addition, diagenesis in this Cretaceous sandstone is interpreted in relation to the diagenesis of other Mesozoic and Tertiary formations in the Gulf Coast.

The Travis Peak Formation produces gas and oil in the study area: much of the gas production is from low-permeability sandstones that require hydraulic fracture treatment for production at economic rates. Extensive cementation of Travis Peak sandstones is the reason for their generally low permeability. An understanding of the diagenetic history of 


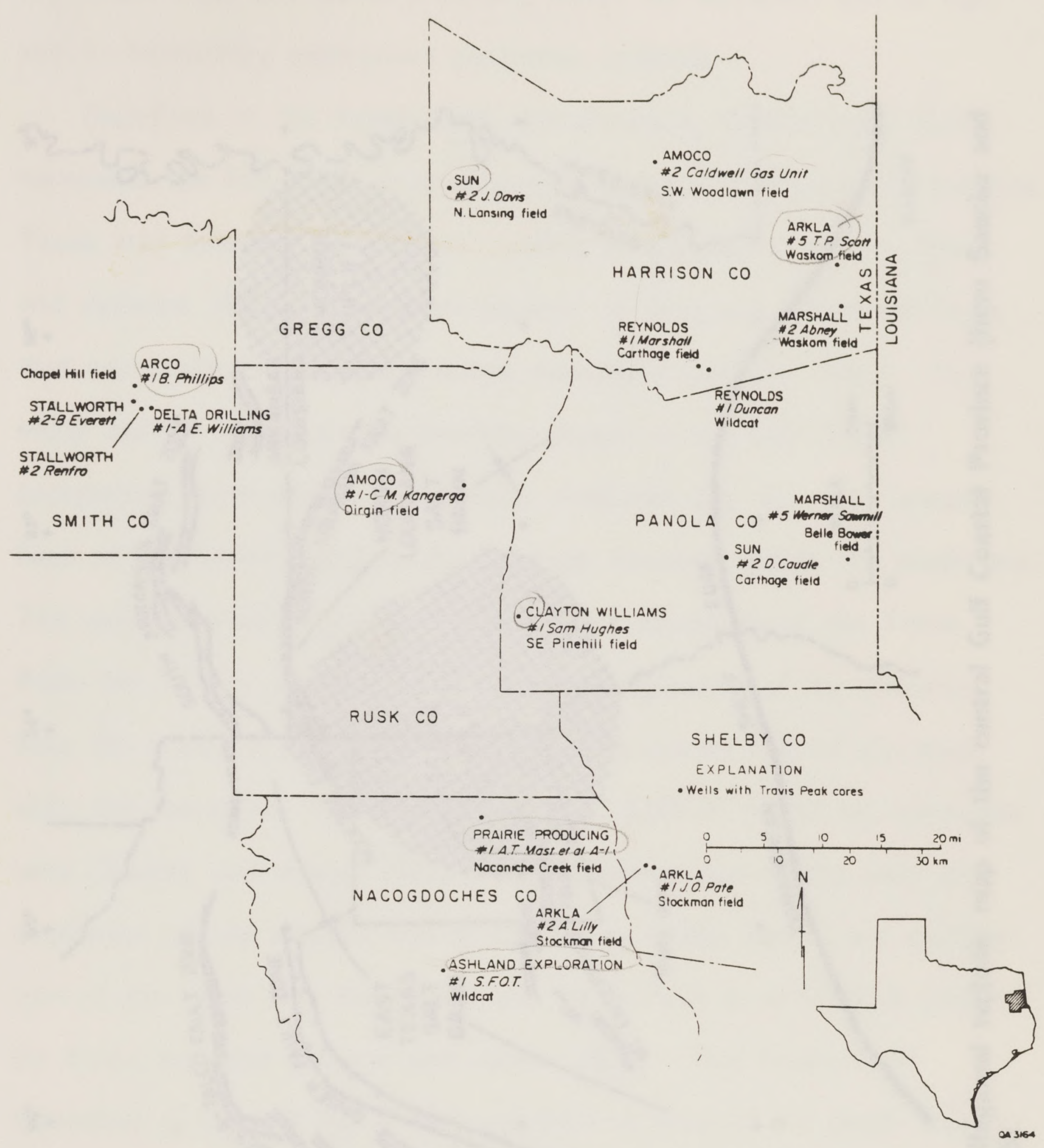

Figure 1. Location of study area and wells from which Travis Peak cores were available. 


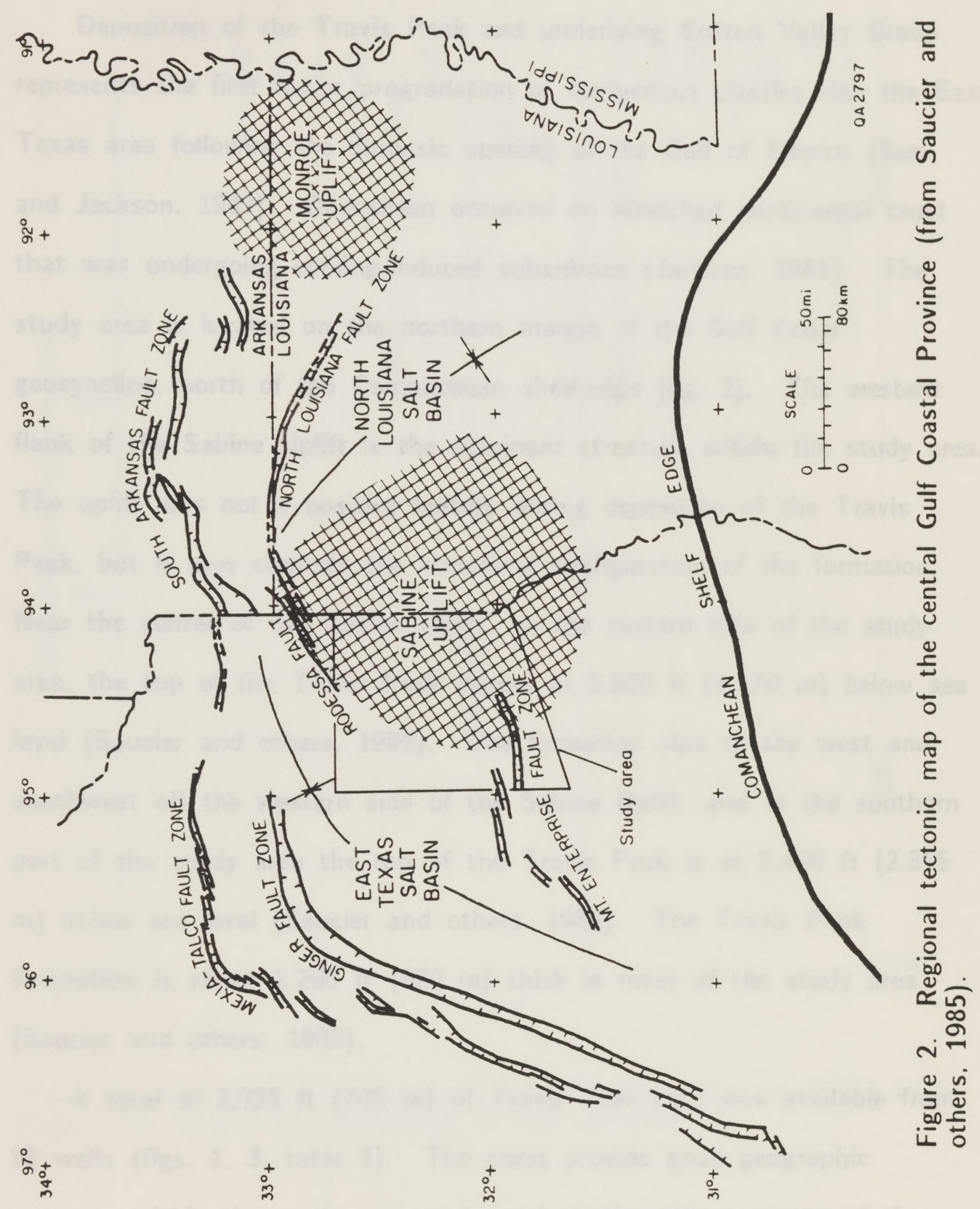


the Travis Peak can aid in predicting where the formation will be tight and in determining appropriate production methods.

Deposition of the Travis Peak and underlying Cotton Valley Group represents the first major progradation of terrigenous clastics into the East Texas area following the Jurassic opening of the Gulf of Mexico (Seni and Jackson, 1983). Deposition occurred on stretched continental crust that was undergoing cooling-induced subsidence (Jackson, 1981). The study area is located on the northern margin of the Gulf Coast geosyncline, north of the Comanchean shelf-edge (fig. 2). The western flank of the Sabine Uplift is the dominant structure within the study area. The uplift was not a positive feature during deposition of the Travis Peak, but it now controls the structural configuration of the formation. Near the center of the Sabine Uplift, on the eastern side of the study area, the top of the Travis Peak occurs at $5.800 \mathrm{ft}(1.770 \mathrm{~m})$ below sea level (Saucier and others, 1985). The formation dips to the west and southwest off the western side of the Sabine Uplift, and in the southern part of the study area the top of the Travis Peak is at $9.400 \mathrm{ft}(2.865$ m) below sea level (Saucier and others, 1985). The Travis Peak Formation is about $2.200 \mathrm{ft}(670 \mathrm{~m})$ thick in most of the study area (Saucier and others, 1985).

A total of $2.325 \mathrm{ft}(709 \mathrm{~m})$ of Travis Peak core was available from 18 wells (figs. 1, 3; table 1). The cores provide good geographic coverage within the study area and good stratigraphic coverage of the entire Travis Peak, although cores from near the top of the formation are 


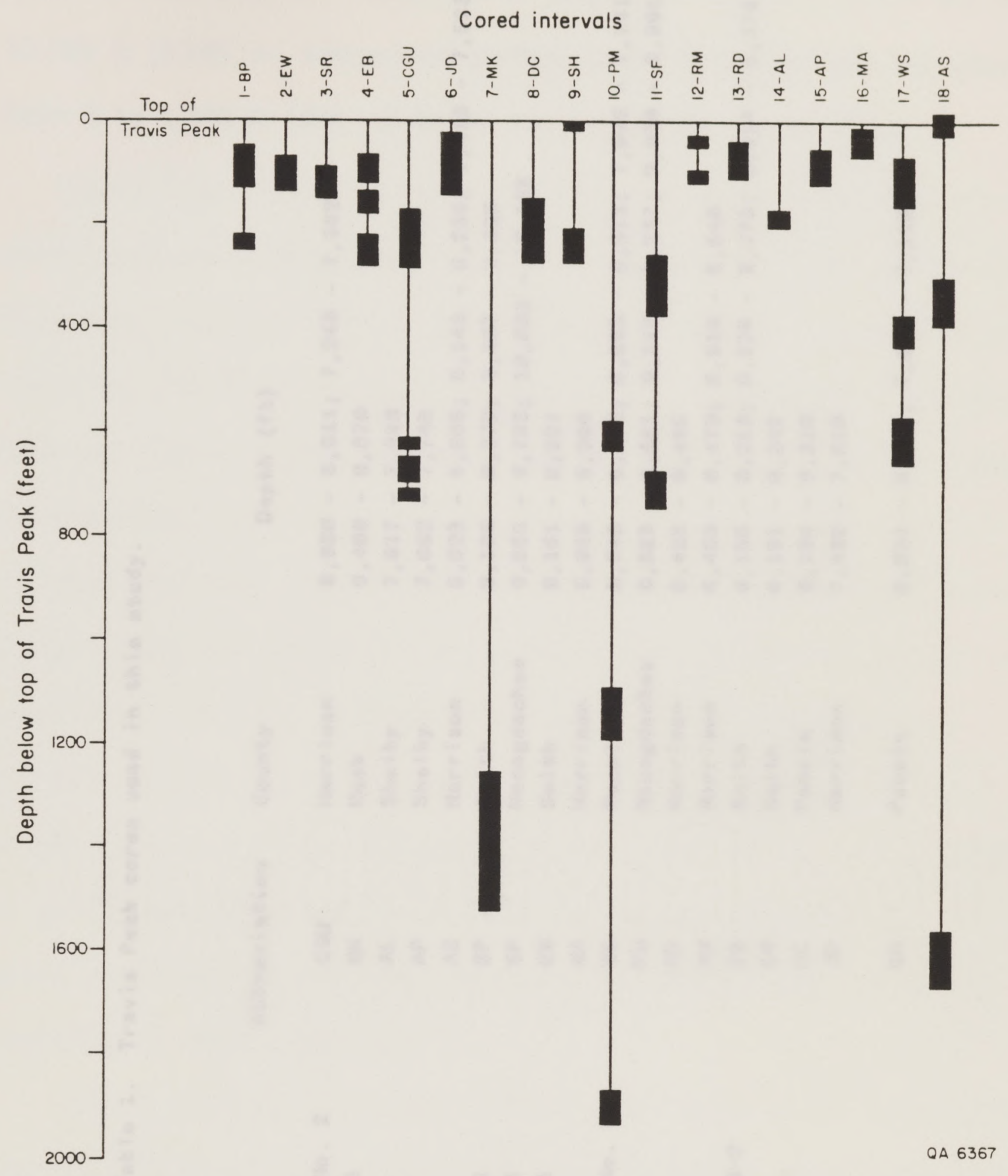

Figure 3. Core control plotted against depth below the top of the Travis Peak. See table 1 for explanation of well abbreviations. 


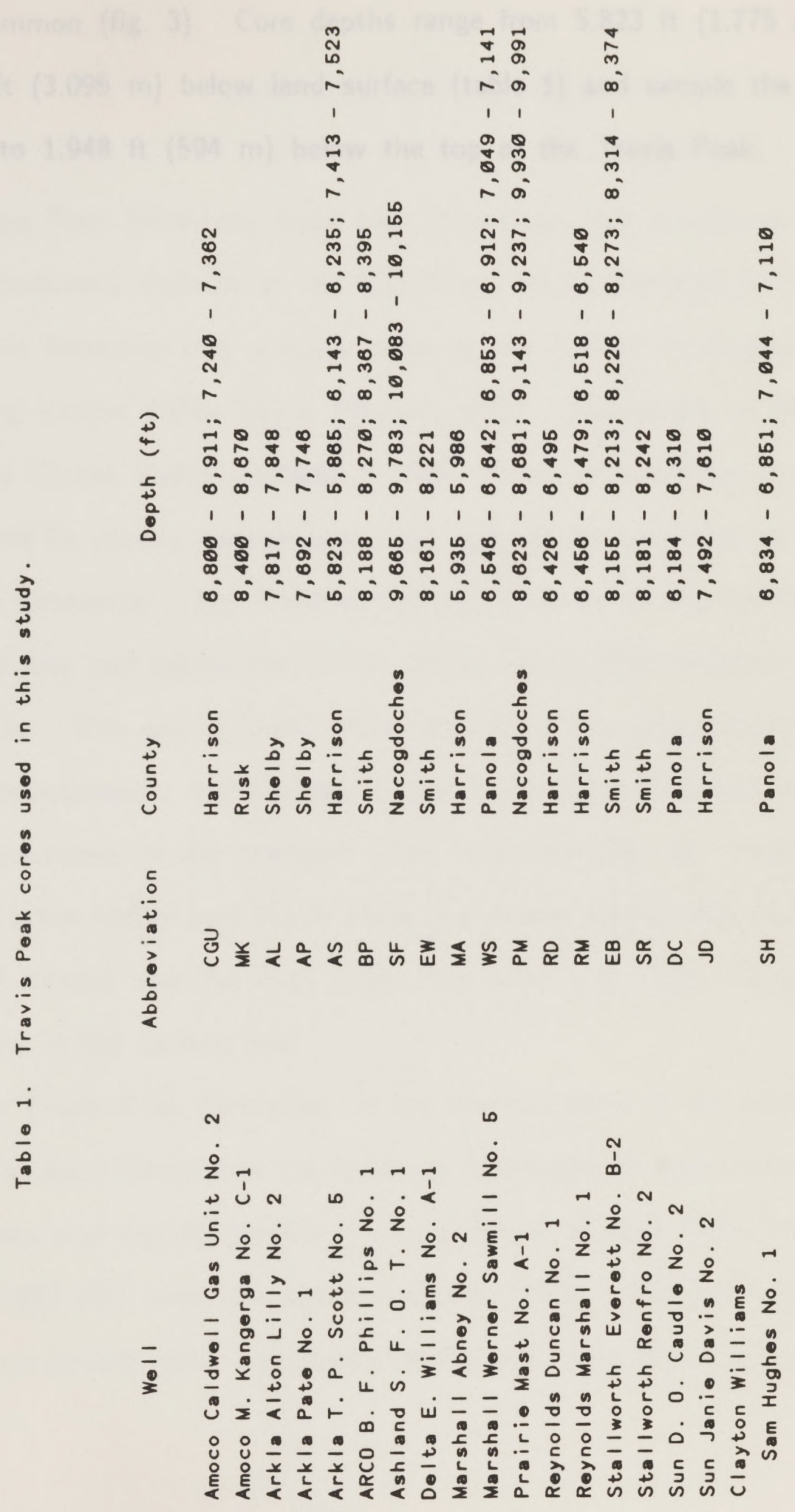


most common (fig. 3). Core depths range from $5.823 \mathrm{ft}(1.775 \mathrm{~m})$ to $10.155 \mathrm{ft}(3.095 \mathrm{~m})$ below land surface (table 1) and sample the interval from 0 to $1.948 \mathrm{ft}(594 \mathrm{~m})$ below the top of the Travis Peak. 


\section{DEPOSITIONAL HISTORY}

Travis Peak (Hosston) rocks (fig. 4) are generally considered the oldest Cretaceous deposits in the Gulf Coast Basin, although the JurassicCretaceous boundary may actually occur in the Schuler Formation in the underlying Cotton Valley Group (Saucier, 1985). Sandstones of the Travis Peak and Cotton Valley represent a major clastic progradation that was interrupted by marine transgression that resulted in deposition of the Knowles Limestone. The Knowles Limestone occurs at the top of the Cotton Valley and marks the Cotton Valley-Travis Peak boundary in the study area. The end of Travis Peak deposition was also marked by marine transgression, and the top of the Travis Peak is picked at the base of the limestones of the overlying Sligo Formation (fig. 4). Progradation of the Cotton Valley and Travis Peak sandstones marked the first major influx of clastics into the East Texas area after Gulf Coast rifting and deposition of the Louann salt.

The Travis Peak Formation on the western flank of the Sabine Uplift (fig. 2) in East Texas was deposited as a complex of high-constructive delta lobes that rapidly prograded over a broad, shallow shelf more than $100 \mathrm{mi}(160 \mathrm{~km})$ wide (Saucier and others, 1985). Because the delta systems prograded onto a competent substrate, they spread laterally as 


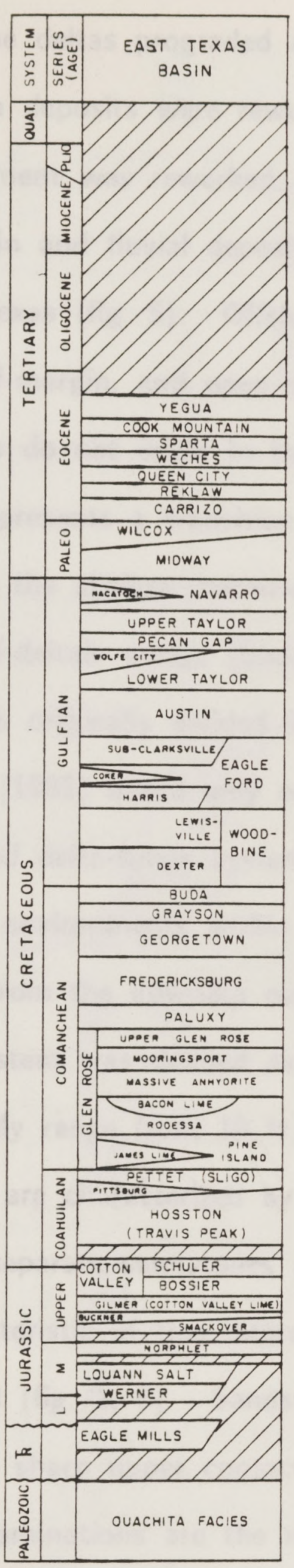

Figure 4. Stratigraphic nomenclature for the East Texas Basin (modified from Galloway and others. 1983). 
well as vertically. As the deltas prograded and shifted across the stable. shallow shelf, initial delta deposits were reworked by fluvial processes. Most of the marine sediment was reworked, leaving a sand-rich accumulation of delta-plain and fluvial deposits that is more than $2.000 \mathrm{ft}$ $(600 \mathrm{~m})$ thick in East Texas (fig. 5). Offshore from the fluvial-deltaic wedge, marine-shelf, shelf-margin, and open-marine systems developed (fig. 5): these downdip facies do not occur in the study area. A delta-fringe system (fig. 5), which represents a transition zone between the continental fluvial-deltaic system and the shallow-marine-shelf system, formed around the margins of the fluvial-deltaic wedge (Saucier, 1985).

The Travis Peak was originally divided into depositional systems by Seni (1983) and Saucier (1985) based only on geophysical logs. Cores from the fluvial-deltaic and delta-fringe systems have made it possible to interpret the depositional environments within these systems more precisely. No cores were available from the downdip marine systems.

The fluvial-deltaic system was defined as a sand-rich unit with stacked sandstones that individually range from $10 \mathrm{ft}(3 \mathrm{~m})$ to more than $50 \mathrm{ft}(15$ m) thick: the sandstones are characterized by blocky SP log patterns (Seni. 1983). Mudstones that separate sandstones are thin and are not laterally continuous. Cores characteristic of this interval were recovered from the Prairie Mast No. 1-A well (fig. 1, 6). Sandstones from this core have sharp bases and relatively sharp upper contacts (fig. 6). Crossbeds and planar-to-slightly-inclined laminations are the most common sedimentary structures throughout entire sandstone intervals; current ripple marks are of 


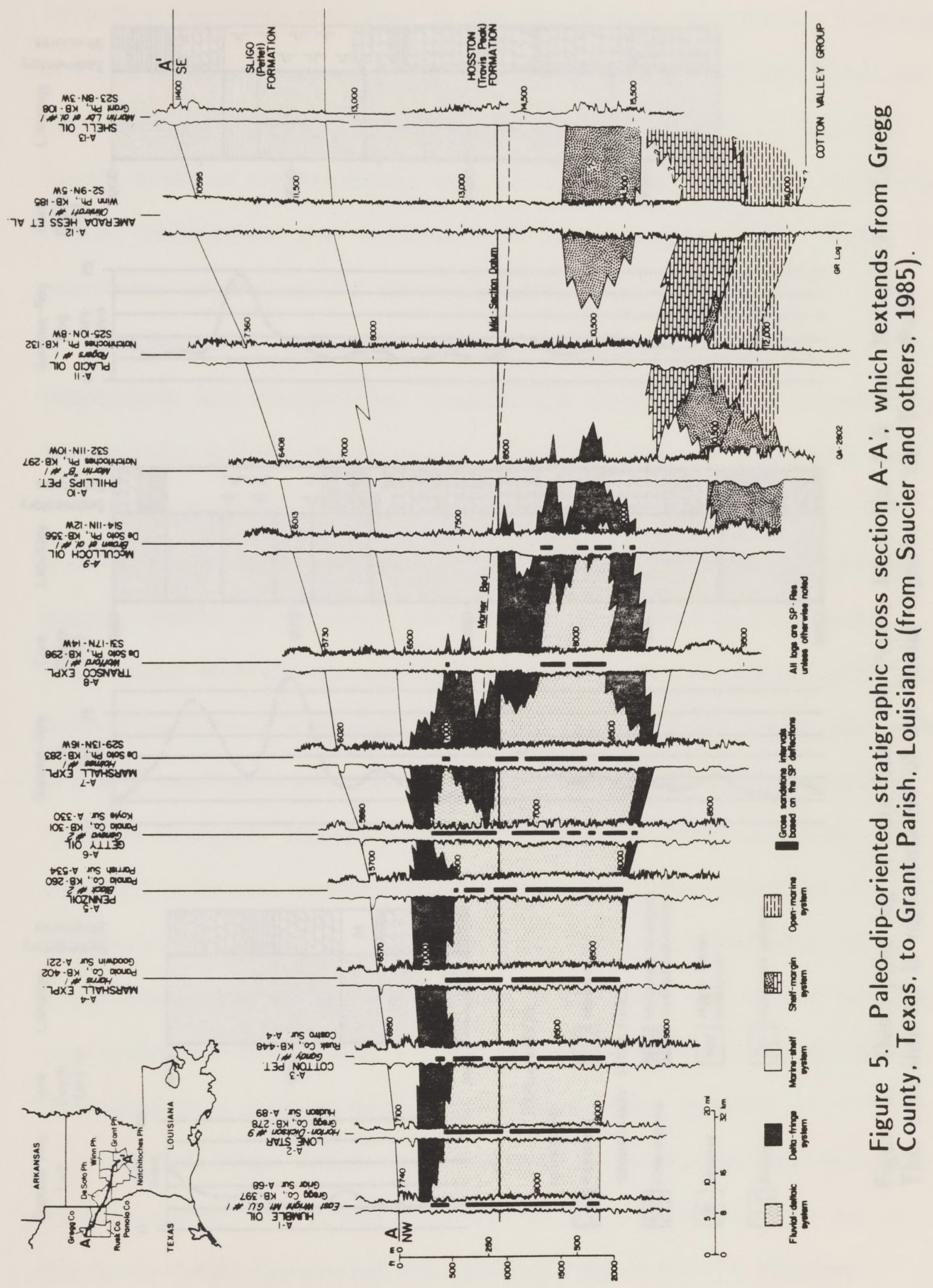



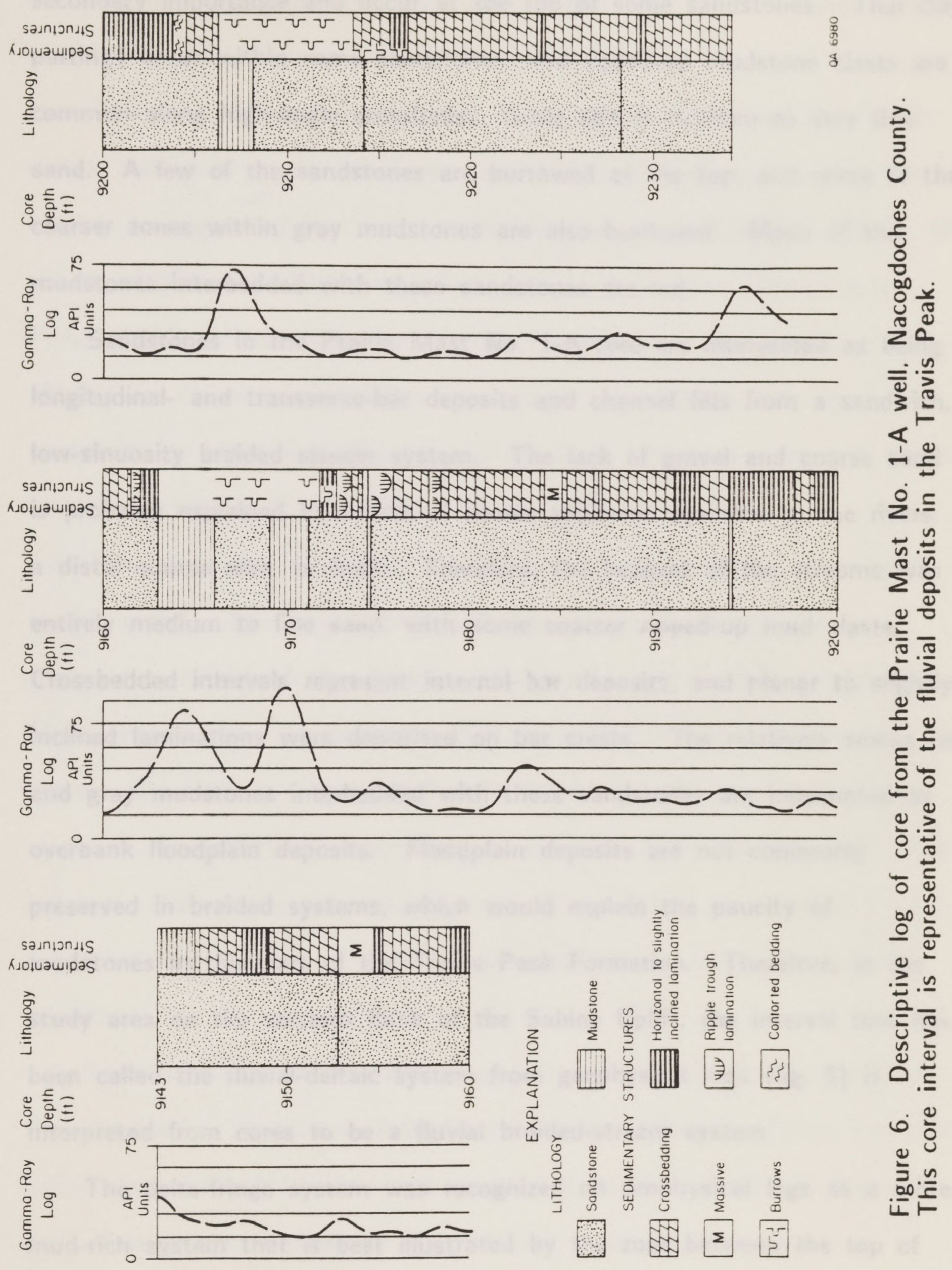
secondary importance and occur at the top of some sandstones. Thin clay partings occur within some sandstones, and ripped-up mudstone clasts are common along high-angle crossbeds. Grain size is medium to very fine sand. A few of the sandstones are burrowed at the top. and some of the coarser zones within gray mudstones are also burrowed. Many of the mudstones interbedded with these sandstones are red.

Sandstones in the Prairie Mast No. 1-A core are interpreted as being longitudinal- and transverse-bar deposits and channel fills from a sand-rich. low-sinuosity braided stream system. The lack of gravel and coarse sand is probably explained by a lack of coarse sediment available to the rivers. a distal source area, or both. Therefore, the bedload of the streams was entirely medium to fine sand, with some coarser ripped-up mud clasts. Crossbedded intervals represent internal bar deposits, and planar to slightlyinclined laminations were deposited on bar crests. The relatively scarse red and gray mudstones interbedded with these sandstones are interpreted as overbank floodplain deposits. Floodplain deposits are not commonly preserved in braided systems, which would explain the paucity of mudstones in this part of the Travis Peak Formation. Therefore, in the study area on the western flank of the Sabine Uplift, the interval that has been called the fluvial-deltaic system from geophysical logs (fig. 5) is interpreted from cores to be a fluvial braided-stream system.

The delta-fringe system was recognized on geophysical logs as a more mud-rich system that is best illustrated by the zone between the top of the fluvial-deltaic system and the overlying Sligo Formation (Saucier. 
1985)(fig. 5). As interpreted from geophysical logs, the delta-fringe system also borders the downdip edge of the fluvial-deltaic system and forms a transition zone between the Knowles Limestone and the sand-rich fluvialdeltaic section of the Travis Peak (fig. 5). Sandstones in the delta-fringe system are separated by thicker mudstones and most commonly display SP curves with a sharp base and upward-fining log patterns (Dutton and Finley, 1986). Cores from the Clayton Williams Sam Hughes No. 1 well (fig. 7) are characteristic of the delta fringe. Sandstones with upwardcoarsening or irregular-serrate log patterns have also been recognized in the delta-fringe system (Fracasso and others, 1986).

Cores from the delta-fringe system were recovered from several wells in this study. The rocks in the delta-fringe system are interpreted to represent a variety of depositional environments. At the base of the deltafringe system, near the boundary with the underlying sand-rich fluvial system, the rocks are interpreted to be fluvial deposits from mixed-load streams. The abundant mudstones are overbank floodplain deposits, which are more likely to be preserved in a mixed-load fluvial environment than in a braided-stream system. Crevasse-splay sandstones within floodplain mudstones are also commmon.

Rocks deposited in the delta-fringe system near the top of the Travis Peak Formation show more indication of marine influence. Rocks from the upper part of the delta-fringe system are lithofacies deposited in lowerdelta-plain, marsh, estuary or bay, tidal-flat, and distributary-bar environments (Saucier and others, 1985). Deposition occurred in a low- 

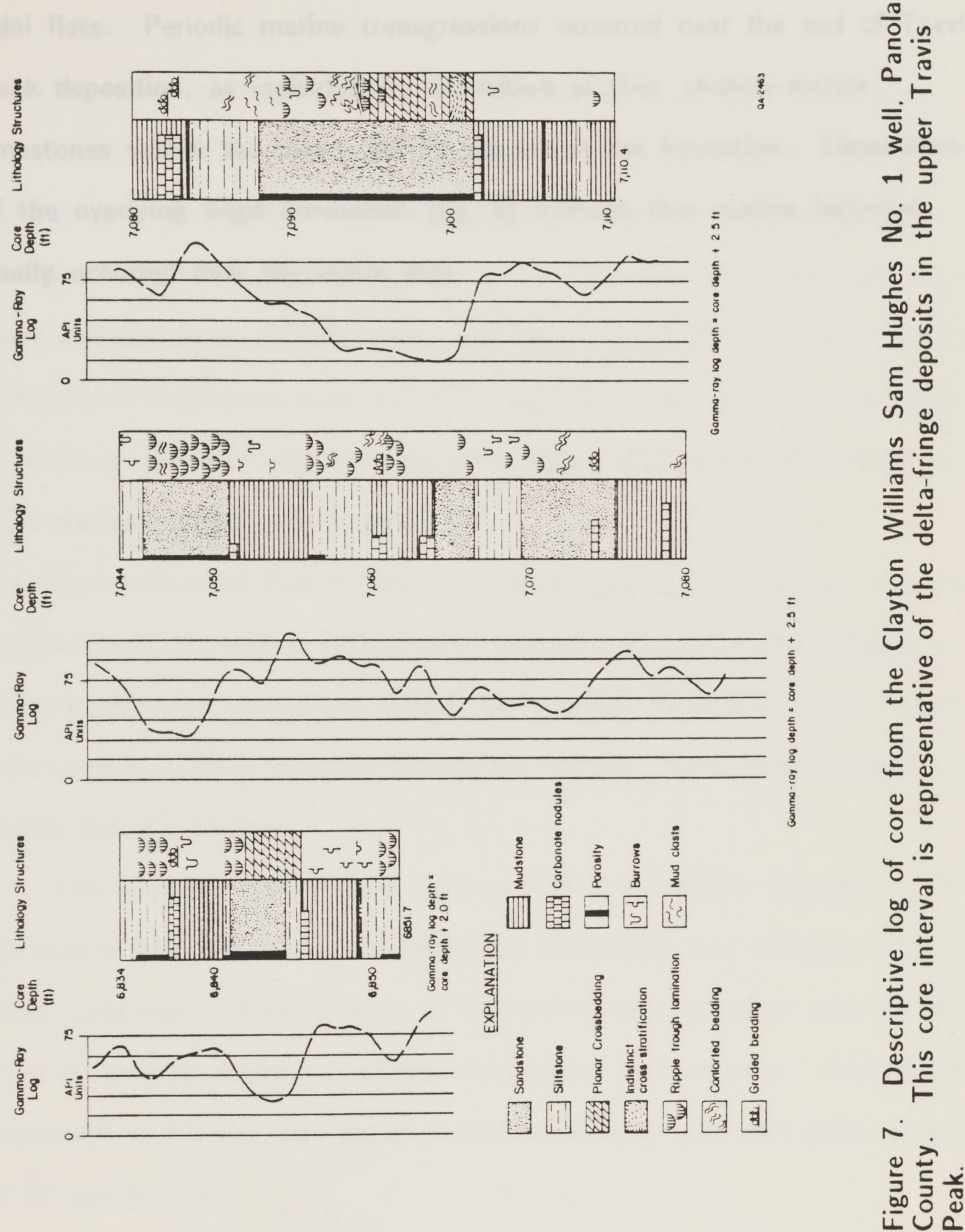
relief shoreline zone where environments changed with sediment compaction. localized progradation of distributaries, and progradation or aggradation of tidal flats. Periodic marine transgressions occurred near the end of Travis Peak deposition, as indicated by deposition of thin, shallow-marine limestones within the upper $100 \mathrm{ft}(30 \mathrm{~m})$ of the formation. Limestones of the overlying Sligo Formation (fig. 4) indicate that marine incursion finally occurred over the entire area. 


\section{METHODS}

The composition of Travis Peak sandstones was determined using samples from 18 cores that provided good geographic (fig. 1) and stratigraphic distribution (fig. 3) within the six-county study area on the western flank of the Sabine Uplift. From each core, representative samples were selected from different facies and from the total depth range available. Matrix-free sandstones were sampled most commonly because cementation in clean sandstones was more extensive than cementation in sandstones that contain detrital clay matrix.

Composition of Travis Peak sandstones and mudstones was determined by standard thin-section petrography, cathodoluminescent petrography. scanning electron microscopy (SEM) with energy dispersive $\mathrm{X}$-ray spectrometer (EDX), electron microprobe analysis, X-ray analysis, and stable isotopic analysis.

Thin sections were treated with sodium cobaltinitrite to stain potassium feldspars and with potassium ferricyanide and alizaren red-S to stain carbonates. Point counts of 200 points were done on each of 255 thin sections to determine mineral composition and porosity. Analysis of framework grain size was accomplished by making grain-size point counts of 50 points each. 
Stable isotopic analysis of authigenic quartz was performed on 33 samples with a wide range in volume percentage of quartz overgrowths as determined by thin-section point counts. Sample material for isotopic analysis came from chips that remained after thin sections were made. Samples were treated with $\mathrm{NaHSO}_{4}$ and $\mathrm{H}_{2} \mathrm{SiF}_{6}$ by the method of Syers et al (1968) to isolate detrital quartz and quartz overgrowths; treated samples were $\mathrm{X}$-rayed to determine purity.

Samples for analysis of dolomite and ankerite cements were powdered. $\mathrm{X}$-rayed, and combined with anhydrous phosphoric acid to generate carbon dioxide gas using the method of $\mathrm{McCrea}$ (1950). Reaction took place in a bath at $77^{\circ} \mathrm{F}\left(25^{\circ} \mathrm{C}\right)$ or $122^{\circ} \mathrm{F}\left(50^{\circ} \mathrm{C}\right)$. In several of the samples, the measured isotopic values represented a combination of dolomite and ankerite cements. Thin section data were used to determine the relative abundance of the two cements in each sample based on point counts of a thin section made from a chip adjacent to the one used for isotopic analysis. 


\section{TRAVIS PEAK COMPOSITION}

The Travis Peak Formation in East Texas is composed mainly of fineto very-fine grained sandstone, muddy sandstone, and sandy mudstone. Matrix-free sandstones are well sorted and texturally mature, according to the definition of Folk (1974). Sandstone composition can be divided into four major parts: framework grains, matrix, cement, and porosity.

\section{Framework Grains}

Travis Peak sandstones are quartzarenites and subarkoses, and the average composition is $\mathrm{Q}_{95.0} \mathrm{~F}_{3.8} \mathrm{R}_{1.2}$ (fig. 8). Quartz is the most abundant detrital mineral in all Travis Peak samples. It comprises an average of $65.5 \%$ of the total sandstone volume and forms between $82 \%$ and $100 \%$ of the essential constituents (quartz, feldspar, and rock fragments). Most detrital quartz grains are single crystals with straight or slightly undulose extinction. although polycrystalline quartz grains are also present.

Feldspar

Detrital feldspars now form an average of $2.7 \%$ of the total sandstone 


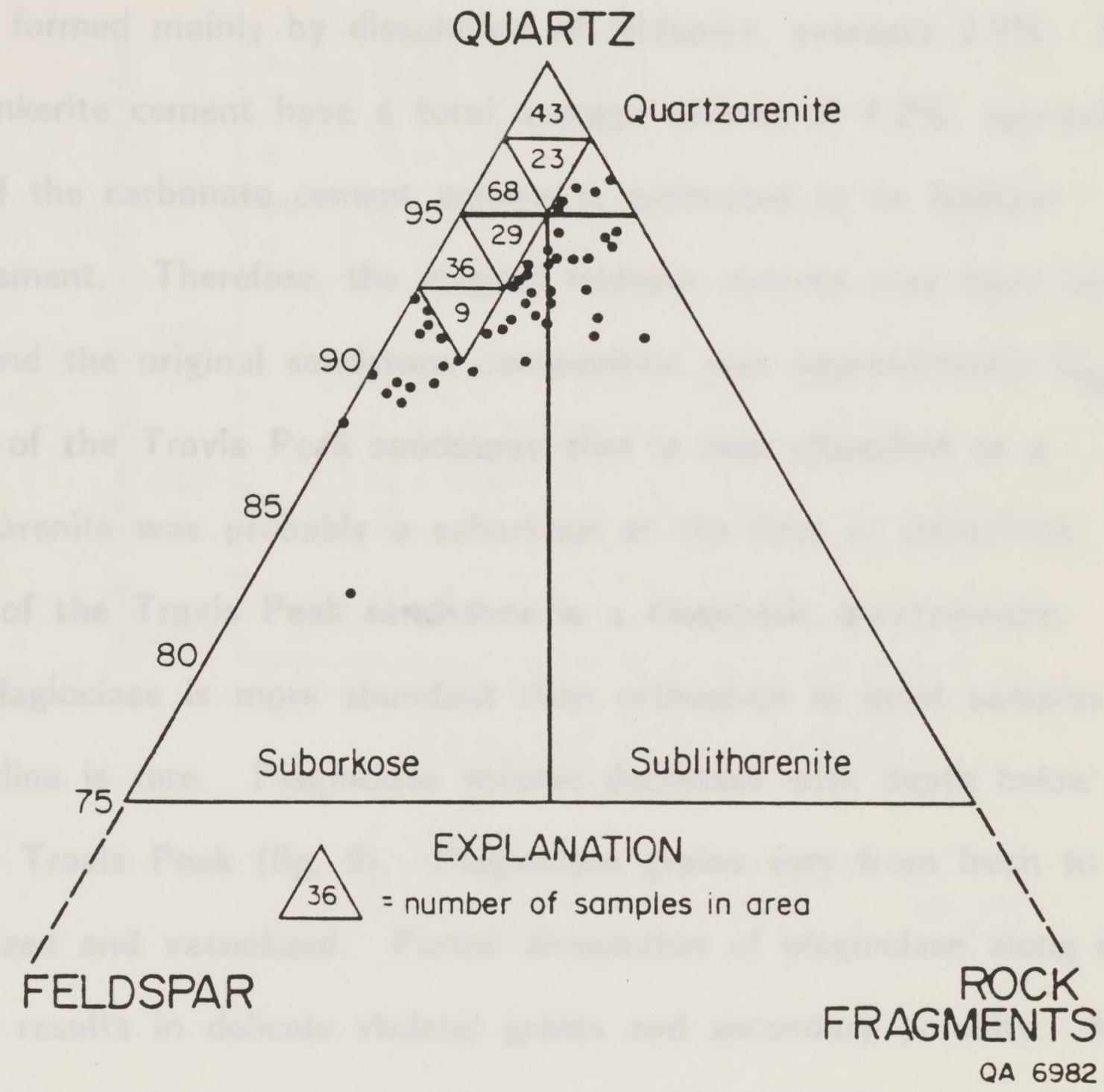

Figure 8. Classification of Travis Peak sandstone samples using Folk's (1974) classification. 
volume and $0 \%$ to $15 \%$ of the essential constituents. Feldspar content was greater at the time of deposition because some feldspar has been lost by dissolution and replacement by carbonate cements. Secondary porosity, which formed mainly by dissolution of feldspars, averages $2.0 \%$. Dolomite and ankerite cement have a total average volume of $4.2 \%$; approximately half of the carbonate cement volume is estimated to be feldspar replacement. Therefore, the original feldspar content may have been about $9 \%$, and the original sandstone composition was approximately $Q_{90} F_{9} R_{1}$. Much of the Travis Peak sandstone that is now classified as a quartzarenite was probably a subarkose at the time of deposition. Thus, some of the Travis Peak sandstone is a diagenetic quartzarenite.

Plagioclase is more abundant than orthoclase in most samples, and microcline is rare. Plagioclase volume decreases with depth below the top of the Travis Peak (fig. 9). Plagioclase grains vary from fresh to sericitized and vacuolized. Partial dissolution of plagioclase along cleavage planes results in delicate skeletal grains and secondary porosity. Many plagioclase grains are untwinned or have albite twinning, but other grains have a patchy, indistinct type of extinction called "chessboard" that is caused by albitization and healing of partially dissolved plagioclase (Gold. 1984). 


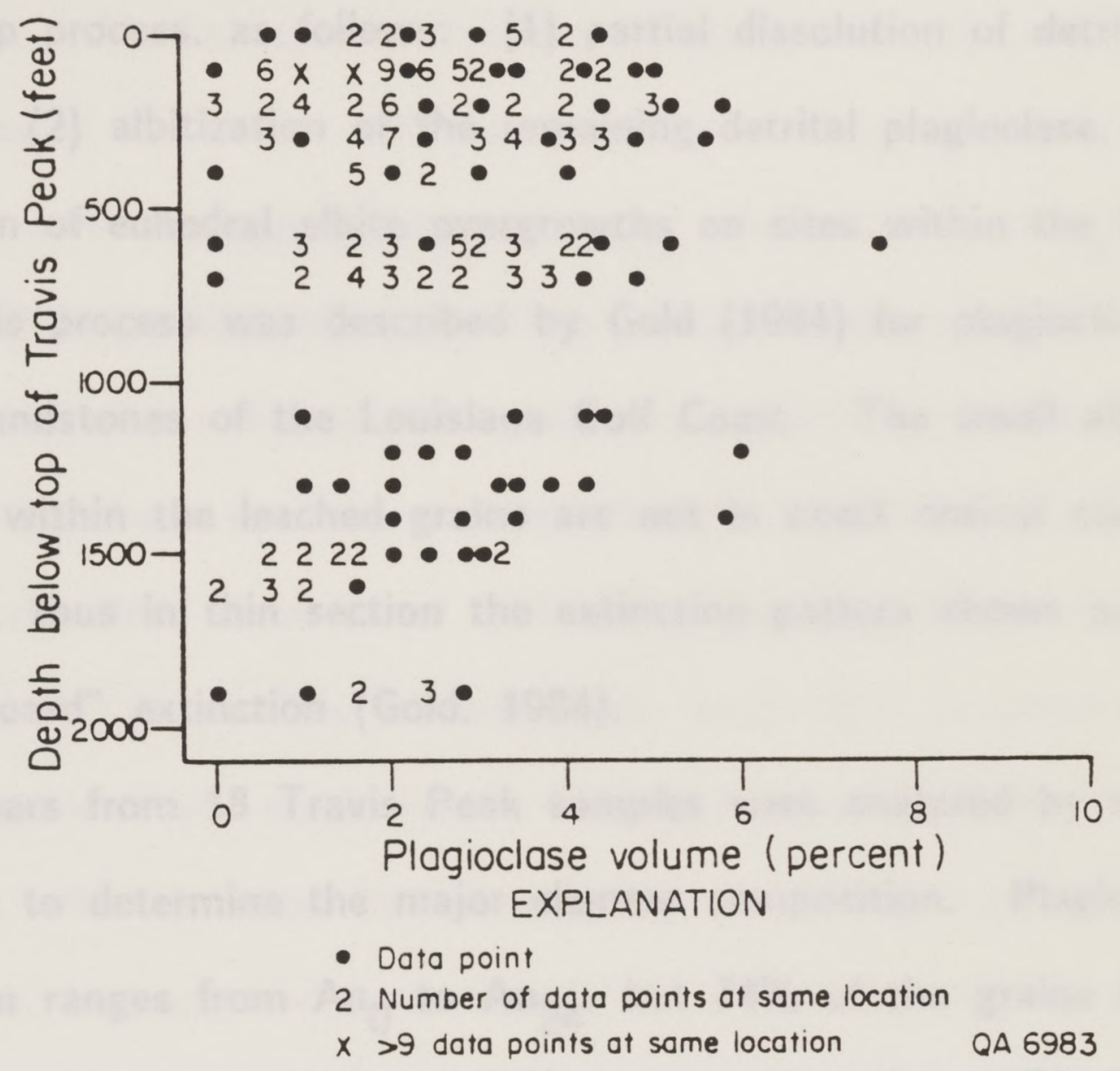

Figure 9. Plagioclase volume as a function of depth below the top of the Travis Peak. 


\section{Plagioclase}

Plagioclase grains in the Travis Peak have been extensively albitized by a three-step process, as follows: (1) partial dissolution of detrital plagioclase. (2) albitization of the remaining detrital plagioclase, and (3) precipitation of euhedral albite overgrowths on sites within the leached grain. This process was described by Gold (1984) for plagioclase in Miocene sandstones of the Louisiana Gulf Coast. The small albite crystals that grow within the leached grains are not in exact optical continuity with each other, thus in thin section the extinction pattern shows patchy zones or "chessboard" extinction (Gold, 1984).

Feldspars from 18 Travis Peak samples were analyzed by electron microprobe to determine the major element composition. Plagioclase composition ranges from $\mathrm{An}_{0}$ to $\mathrm{An}_{24}$, but $74 \%$ of the grains that were analysed are less than $A n_{2}$ and $86 \%$ are less than $A n_{5}$. Plagioclase grains with chessboard extinction consistently have compositions less than $\mathrm{An}_{2}$. Feldspars that retain calcium (greater than $\mathrm{An}_{10}$ ) represent a variety of grain types, including grains with distinct albite twinning, untwinned grains. and extensively dissolved grains. However, other examples of each of these grain types have compositions of less than $\mathrm{An}_{2}$. Therefore, only grains with chessboard extinction are consistently associated with albite composition of less than $\mathrm{An}_{2}$.

Microprobe analyses indicate that plagioclase in the Travis Peak is highly albitic. The original detrital composition of the plagioclase is not 
known, but it was probably more calcic than it is now. possibly in the range $A n_{10}$ to $A n_{50}$. The presence of plagioclase with $A n_{24}$ in the Travis Peak indicates that the source area contained feldspars at least as calcic as oligoclase. Medium-grade metamorphic rocks and igneous diorites and granodiorites in the source area (see section on Provenance) could have contributed both oligoclase $\left(A n_{10}\right.$ to $\left.A n_{30}\right)$ and andesine $\left(A n_{30}\right.$ to $\left.A n_{50}\right)$. Therefore, it is probable that the Travis Peak feldspars were albitized after burial. Many of the Travis Peak plagioclase grains are extensively leached and would not have survived transport in this condition, indicating they have been dissolved since burial. Similarly, the precipitation of internal overgrowths within partially leached grains must have occurred since burial and dissolution of the plagioclase. Therefore, it seems likely that albitization, which involves both dissolution and precipitation of internal overgrowths, has occurred since burial. It is possible that some fraction of the albite in the Travis Peak was inherited from older, albitized sandstones or from low-grade metamorphic rocks in the source area.

The average anorthite content of plagioclase grains does not vary systematically with depth below ground surface, but it decreases with depth below the top of the Travis Peak Formation. Samples in the upper part of the formation have a wide range of average An content, but deeper in the formation the average An content is uniformly low (fig. 10). However, two samples within the upper $100 \mathrm{ft}(30 \mathrm{~m})$ of the formation also have been extensively albitized. One of the samples. from a depth of $8.243 \mathrm{ft}(2.512 \mathrm{~m})$ in the ARCO Phillips No. 1 well, has an average An 


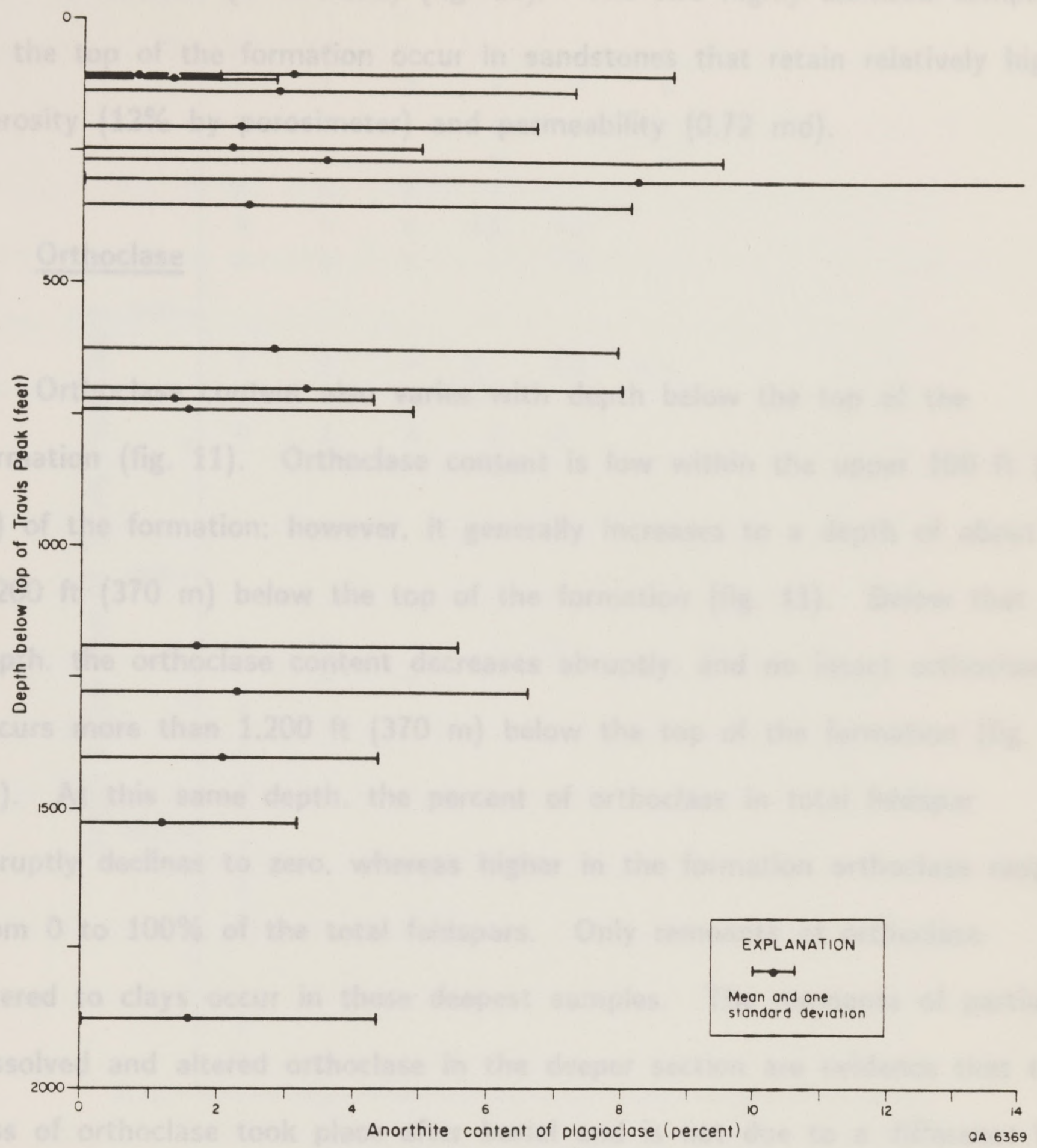

Figure 10. Plagioclase composition as a function of depth below the top of the Travis Peak. The average An content in each sample is shown by a dot, and one standard deviation in An content is shown by the bars. The number of analyses per sample varies from 10 to 31 . 
content of $0.008(\sigma=0.012)$ (fig. 10). The two highly albitized samples at the top of the formation occur in sandstones that retain relatively high porosity $(12 \%$ by porosimeter $)$ and permeability $(0.72 \mathrm{md})$.

\section{$\underline{\text { Orthoclase }}$}

Orthoclase content also varies with depth below the top of the formation (fig. 11). Orthoclase content is low within the upper $100 \mathrm{ft}$ (30 $\mathrm{m})$ of the formation; however, it generally increases to a depth of about $1,200 \mathrm{ft}(370 \mathrm{~m})$ below the top of the formation (fig. 11). Below that depth, the orthoclase content decreases abruptly, and no intact orthoclase occurs more than $1.200 \mathrm{ft}(370 \mathrm{~m})$ below the top of the formation (fig. 11). At this same depth, the percent of orthoclase in total feldspar abruptly declines to zero, whereas higher in the formation orthoclase ranges from 0 to $100 \%$ of the total feldspars. Only remnants of orthoclase altered to clays occur in these deepest samples. The remnants of partially dissolved and altered orthoclase in the deeper section are evidence that the loss of orthoclase took place after burial and is not due to a difference in detrital mineralogy. Low orthoclase content within the upper $100 \mathrm{ft}$ (30 m) of the formation suggests that extensive orthoclase dissolution occurred there as well.

Absolute depth does not seem to be important in determining orthoclase content. In different wells, the depth below which orthoclase does not occur ranges from $7.400 \mathrm{ft}(2.250 \mathrm{~m})$ in the Arkla Scott No. 5 


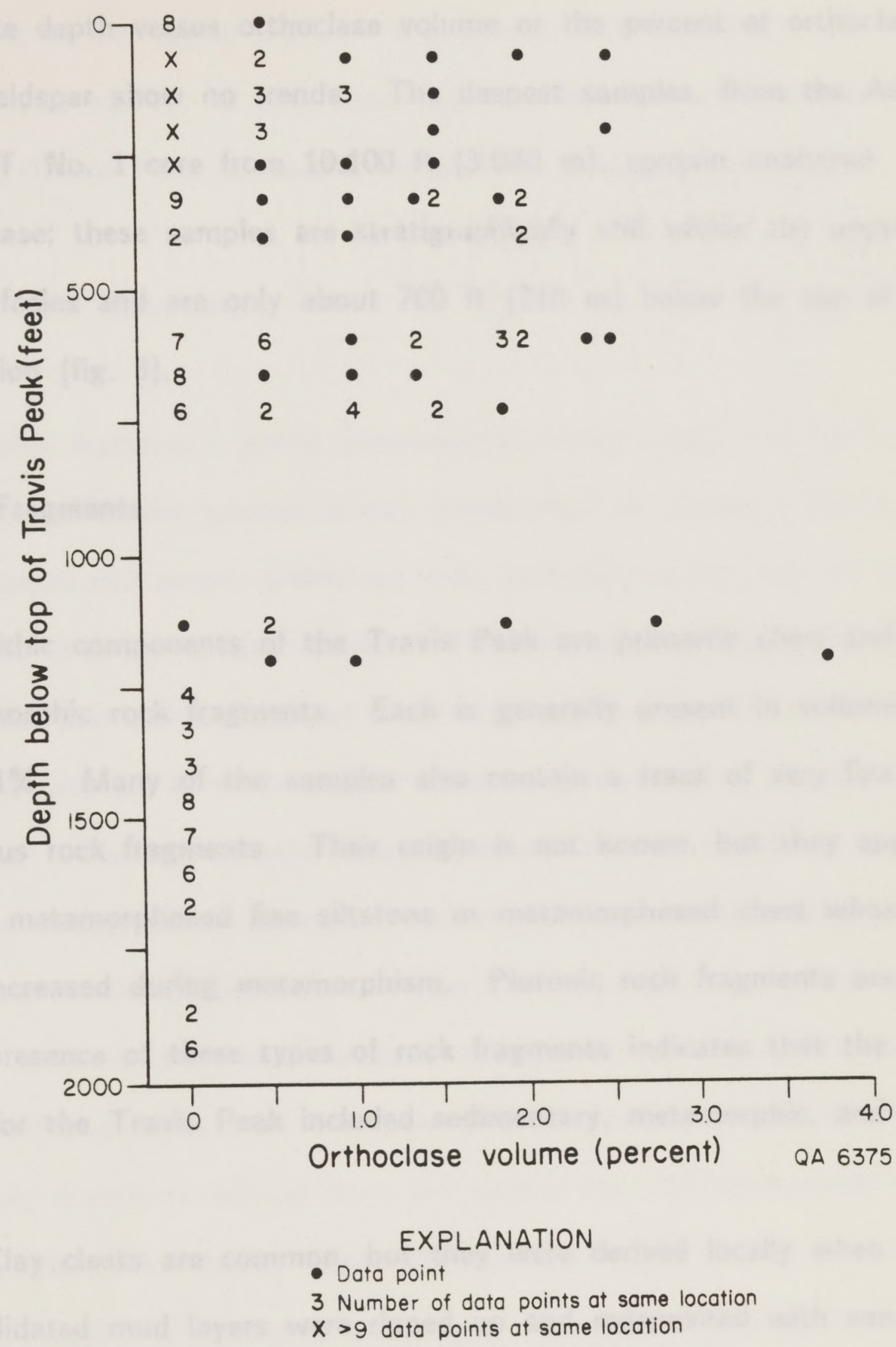

Figure 11. Orthoclase volume as a function of depth below the top of the Travis Peak. Orthoclase is not present more than $1.200 \mathrm{ft}(365 \mathrm{~m})$ below the top of the formation. 
well to $9.900 \mathrm{ft}(3.000 \mathrm{~m})$ in the Prairie Mast No. 1-A well. Plots of absolute depth versus orthoclase volume or the percent of orthoclase in total feldspar show no trends. The deepest samples, from the Ashland S.F.O.T. No. 1 core from $10,100 \mathrm{ft}(3.080 \mathrm{~m})$, contain unaltered orthoclase: these samples are stratigraphically still within the upper deltafringe facies and are only about $700 \mathrm{ft}(210 \mathrm{~m})$ below the top of the formation (fig. 3).

\section{Rock Fragments}

Lithic components of the Travis Peak are primarily chert and low-rank metamorphic rock fragments. Each is generally present in volumes of less than $1 \%$. Many of the samples also contain a trace of very fine grained siliceous rock fragments. Their origin is not known, but they appear to be either metamorphosed fine siltstone or metamorphosed chert whose grain size increased during metamorphism. Plutonic rock fragments are rare. The presence of these types of rock fragments indicates that the source area for the Travis Peak included sedimentary, metamorphic, and igneous rocks.

Clay clasts are common, but they were derived locally when partially consolidated mud layers were ripped up and redeposited with sand. Because of their local origin. clay clasts were not included in the rock fragment category when the sandstones were classified (fig. 8). However, clay clasts are an important detrital constituent because of the loss of 
primary porosity caused by compaction of these ductile grains. Clay clasts comprise an average of $1.2 \%$ of the total sandstone volume and range from 0 and $13.7 \%$. If clay clasts are included with rock fragments, the average Travis Peak sandstone composition is $Q_{93.4} F_{3.8} R_{2.8}$.

Nonessential Constituents

Other framework grains (nonessential constituents) not used to classify the sandstones are present in the Travis Peak in varying amounts.

Tourmaline and zircon, which are both extremely stable, are the only heavy minerals observed in thin section. They can survive long transport distances and can be recycled from older sedimentary rocks. Rutile, a common mineral in metamorphic rocks, was identified in several SEM samples. The lack of other heavy minerals may be attributed to two factors. First, heavy minerals other than zircon and tourmaline were probably rare in the sedimentary part of the source area. Second, other heavy minerals, such as hornblende and garnet, are less stable during transport and burial than are zircon and tourmaline, so any of these minerals that were derived from the source area did not survive transport or were dissolved during diagenesis (Milliken, 1985).

Muscovite is present in volumes of less than $0.5 \%$, and it occurs primarily in the finer grained samples. Coalified wood (vitrinite) is a common constituent in some samples. Invertebrate fossils occur in 
sandstones that are adjacent to fossiliferous limestones near the top of the formation. Oyster fragments are most common fossils in the sandstones.

\section{Provenance}

Travis Peak sandstones are mineralogically mature; unstable grains either were not abundant in the source area (perhaps because of dissolution during weathering), or they were removed during transportation. deposition, and burial, or both. Work by Saucier (1985) indicates that the Travis Peak was derived from a large area of the southwestern United States that was exposed in Early Cretaceous (Coahuilan) time (fig. 12). This source area in the Texas Panhandle. Oklahoma. New Mexico, and Colorado included sedimentary, metamorphic, and igneous rocks (fig. 12). The high percentage of quartz in the Travis Peak is probably caused at least in part by the presence of abundant terrigenous sedimentary rocks in the source area. Metamorphic rocks from the Ouachita Fold Belt probably contributed slate and phyllite fragments, metachert, and much of the plagioclase. Granitic Precambrian basement exposed in Oklahoma and Colorado during the Early Cretaceous contributed feldspar, quartz, and plutonic rock fragments. However, plutonic rock fragments are rare in the Travis Peak sandstones because igneous rocks were a minor part of the source terrain and because the transport distance was sufficiently long that most rock fragments were broken into individual mineral grains. 


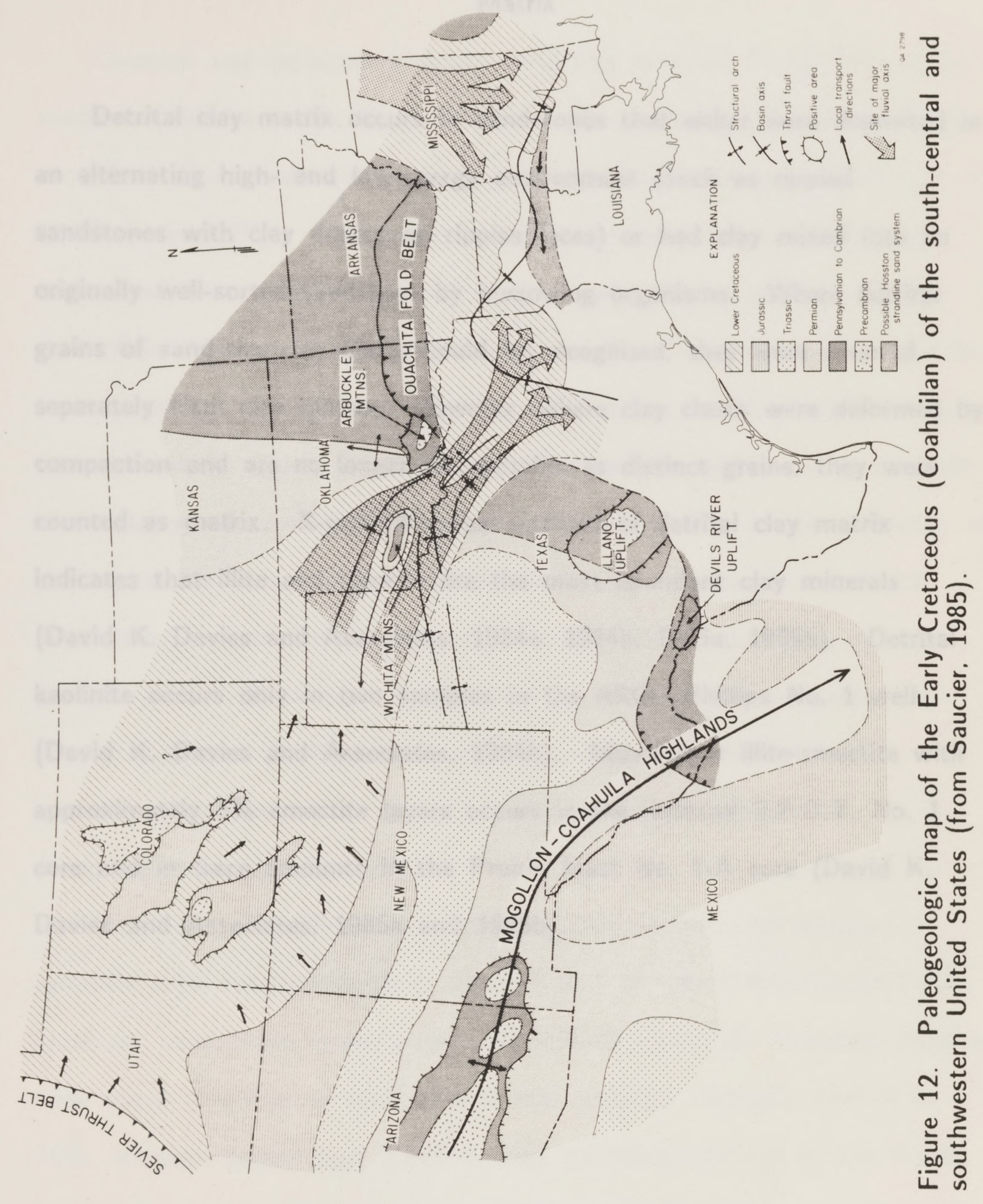




\section{Matrix}

Detrital clay matrix occurs in sandstones that either were deposited in an alternating high- and low-energy environment (such as rippled sandstones with clay drapes on ripples faces) or had clay mixed into an originally well-sorted sandstone by burrowing organisms. Where detrital grains of sand-size clay clasts could be recognized, they were counted separately from clay matrix. However, where clay clasts were deformed by compaction and are no longer recognizable as distinct grains, they were counted as matrix. X-ray diffraction analysis of detrital clay matrix indicates that illite and chlorite are the most abundant clay minerals (David K. Davies and Associates, 1984a, 1984b, 1985a, 1985b). Detrital kaolinite occurs only in two samples in the ARCO Phillips No. 1 well (David K. Davies and Associates, 1984b). Mixed-layer illite-smectite with approximately $5 \%$ smectite layers occurs in the Ashland S.F.O.T. No. 1 core and in trace amounts in the Prairie Mast No. 1-A core (David K. Davies and Associates, 1985a and 1985b). 


\section{Cements}

Cements and replacive minerals constitute between 0 and $70 \%$ of the sandstone volume in the Travis Peak samples. The volume of rock comprised of authigenic minerals is normally distributed with an average of $22.1 \%(\sigma=8.9 \%)$. Four outliers, which are extensively cemented by carbonates, have total volumes of cement and replacive minerals greater than $50 \%$. The most important control on the total volume of cement in sandstones is the amount of detrital matrix: the correlation coefficient between matrix volume and total cement volume is -0.67 . Large amounts of detrital matrix lowered the porosity and permeability of the sediment, so that a smaller volume of mineralizing fluids passed through matrix-rich sandstones compared with clean sandstones. Furthermore, less primary porosity was available for cements to fill in the matrix-rich sandstones. Finally, abundant detrital matrix probably reduced the availability of nucleation sites on detrital grains, and in particular inhibited the precipitation of quartz cement.

There is no significant correlation of total cement and replacive minerals with absolute depth or depth below the top of the Travis Peak. However, sandstones in the upper $700 \mathrm{ft}(213 \mathrm{~m})$ of the formation have a wide range of values of total cement and replacive minerals, from 0 to $70 \%$. whereas deeper than $1.000 \mathrm{ft}(305 \mathrm{~m})$ below the top of the Travis Peak, total volume of cement and replacive minerals has a narrower range of values from about 8 to $32 \%$ (fig. 13). 


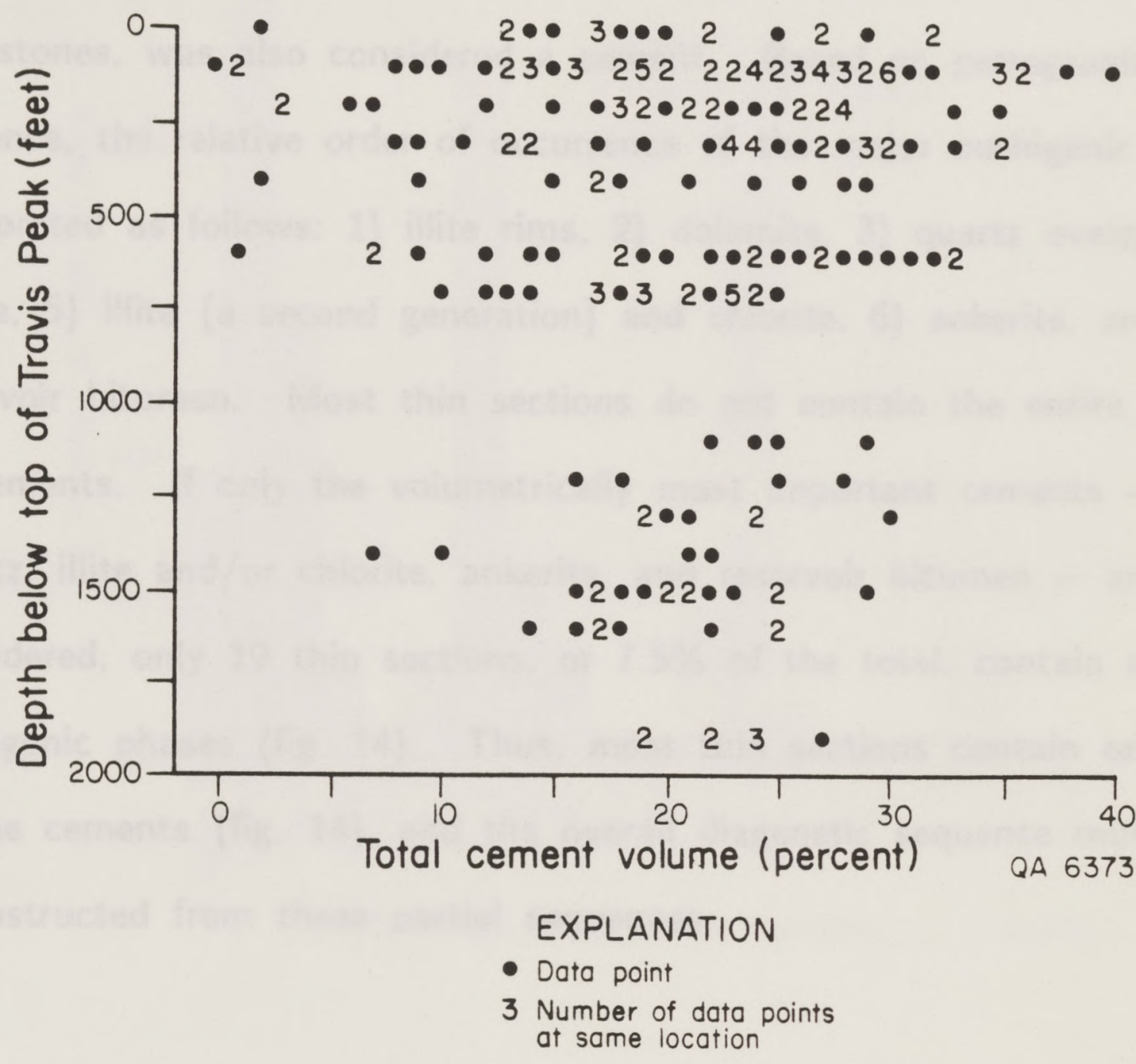

Figure 13. Relation between total volume of cement, including reservoir bitumen, and depth below the top of the Travis Peak. Four outliers with more than $50 \%$ carbonate cement from near the top of the formation have been omitted. 
The most abundant authigenic phases in Travis Peak sandstones are quartz, illite. chlorite, ankerite, and dolomite. Less abundant authigenic minerals include calcite, kaolinite, feldspar, pyrite, barite, and anhydrite. Finally, reservoir bitumen, a solid hydrocarbon residue that occurs in some sandstones, was also considered a cement. Based on petrographic evidence, the relative order of occurrence of the major authigenic phases is interpreted as follows: 1) illite rims, 2) dolomite. 3) quartz overgrowths, 4) albite. 5) illite (a second generation) and chlorite, 6) ankerite, and 7) reservoir bitumen. Most thin sections do not contain the entire sequence of cements. If only the volumetrically most important cements -- dolomite. quartz, illite and/or chlorite, ankerite, and reservoir bitumen -- are considered, only 19 thin sections, or $7.5 \%$ of the total, contain all these authigenic phases (fig. 14). Thus, most thin sections contain only some of the cements (fig. 14), and the overall diagenetic sequence must by reconstructed from these partial sequences.

\section{Authigenic Quartz}

Authigenic quartz is the most abundant cement in Travis Peak sandstones, having an average volume of $13.4 \%(\sigma=6.8 \%)$. In samples with no detrital clay matrix, the average volume of quartz cement is $16.7 \%$ $(\sigma=4.8 \%)$. In samples with abundant quartz cement, the overgrowths completely occlude primary porosity and form an interlocking mesh of quartz crystals (fig. 15). In samples with less authigenic quartz, the 


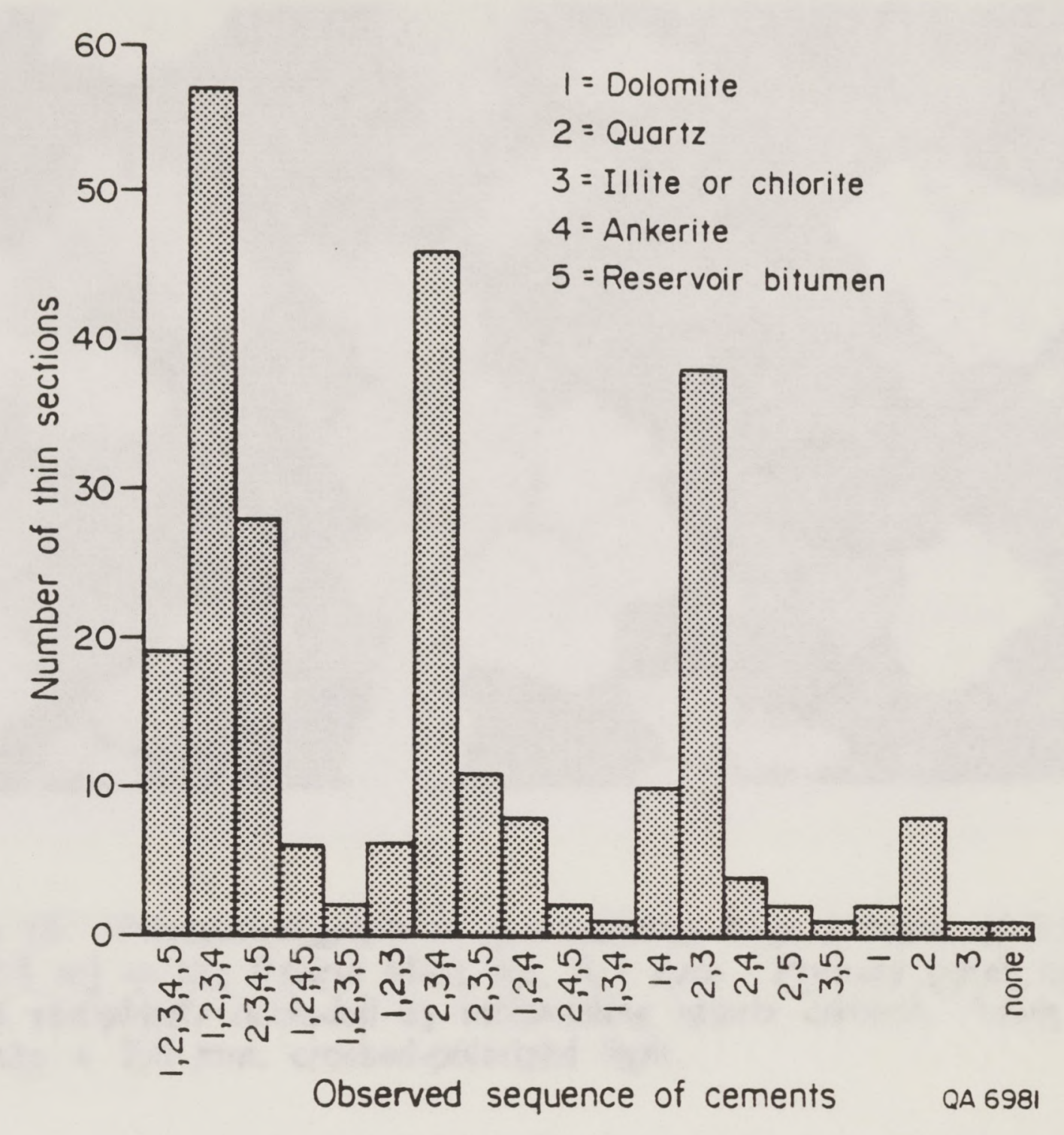

Figure 14. Frequency of observed sequences of major cements in Travis Peak sandstones. The complete sequence of major cements occurs in only $7.5 \%$ of the thin sections. 


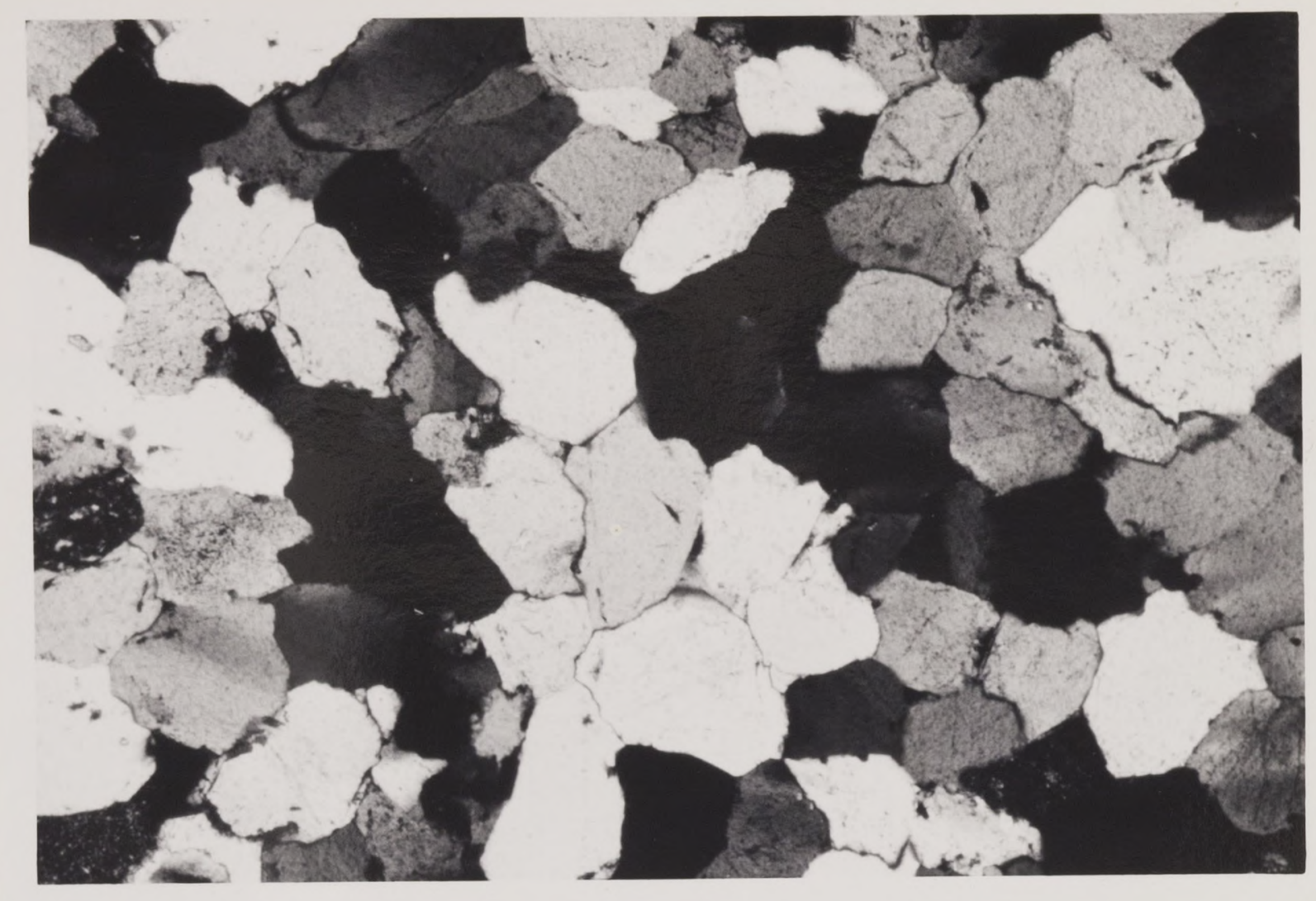

Figure 15. Photomicrograph of quartzarenite from a depth of $9.959 .9 \mathrm{ft}$ $(3.035 .8 \mathrm{~m})$ in the Prairie Mast No. A-1 core. Primary pores have been almost completely occluded by interlocking quartz cement. Long dimension of photo $=2.6 \mathrm{~mm}$; crossed-polarized light. 
overgrowths do not grow together, thus some primary porosity remains between crystal faces (fig. 16). Intervals of high permeability in the Travis Peak correspond to zones of matrix-free sandstone with relatively low volumes of quartz cement.

Quartz overgrowths in Travis Peak sandstones are believed to have formed during burial diagenesis, and, therefore, are not second cycle overgrowths. Most detrital quartz grains in mudstones and matrix-rich sandstones lack euhedral quartz overgrowths or evidence of a previous generation of abraded overgrowths. Rare grains with quartz overgrowths in matrix-rich sandstones and mudstones could be detrital, or the overgrowths could be diagenetic features that are rare because nucleation sites on detrital quartz grains were rare. The rare quartz overgrowths in matrixrich sandstones are not abraded. It seems clear that the vast majority of quartz overgrowths in Travis Peak sandstones formed during this cycle of burial diagenesis.

Evidence of pressure solution is present but rare in Travis Peak thin sections, and some stylolites were observed in cores. Out of 255 thin sections, 18 thin sections contain a total of 60 stylolites. The sum of the maximum column heights of all the stylolites is $15 \mathrm{~mm}$ and represents the minimum thickness of material that was dissolved. Work by Heald (1955) suggests that estimates of thickness of dissolved material that are based on stylolite column height result in values that are 10 times less than estimates based on heavy mineral residues along stylolites. Therefore, as much as $150 \mathrm{~mm}$ may have been removed along the stylolites in these 


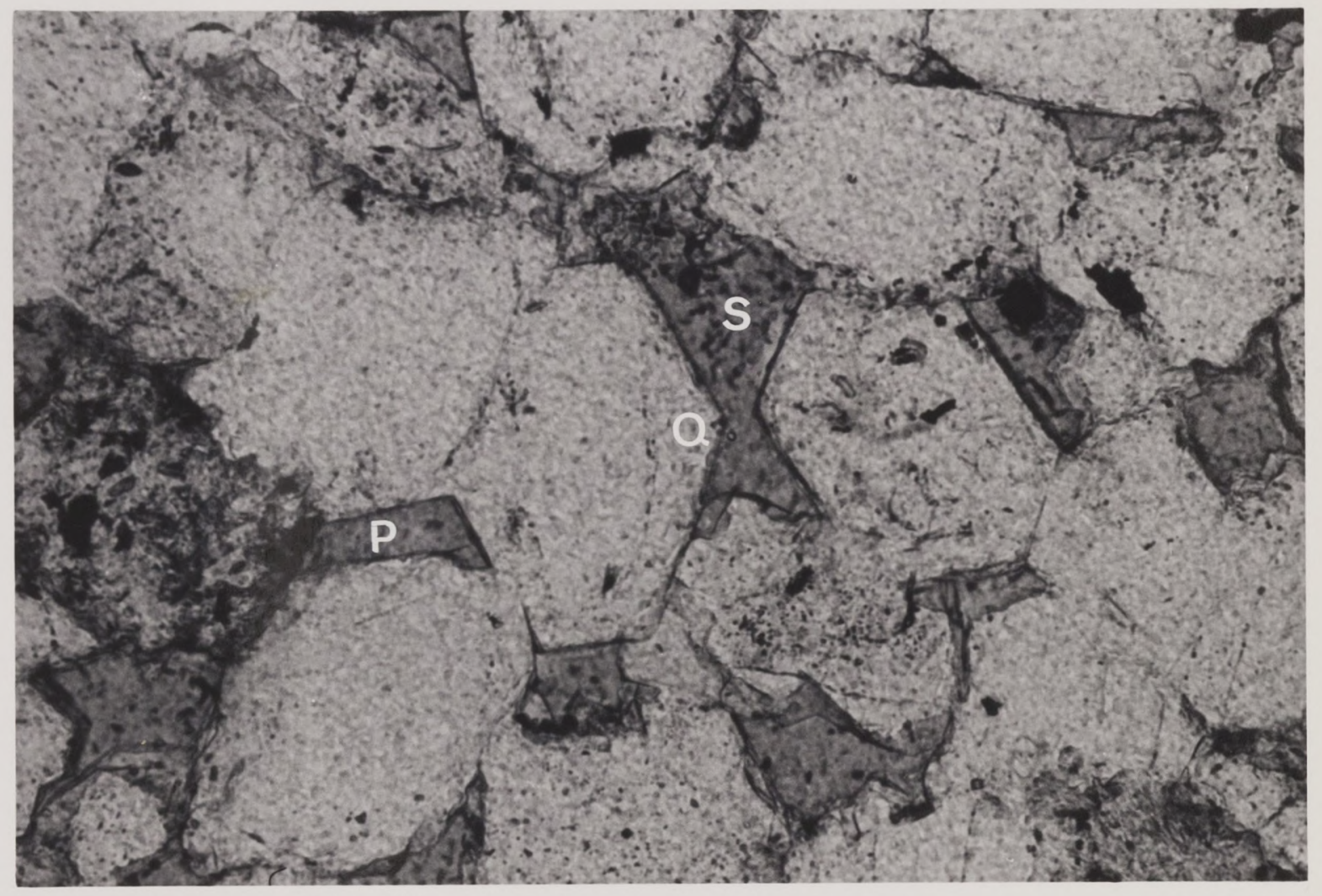

Figure 16. Photomicrograph of primary (P) and secondary (S) pores and euhedral quartz overgrowths (Q) from a depth of $6.843 .7 \mathrm{ft}(2.086 .0 \mathrm{~m})$ in the Clayton Williams Sam Hughes No. 1 core. Long dimension of photo $=2.6 \mathrm{~mm}$ : plane-polarized light. 
samples. The total thickness represented by the thin sections is approximately $9,200 \mathrm{~mm}$. With an average of $13.4 \%$ quartz overgrowths, the volume of silica in quartz cement represents about $1.200 \mathrm{~mm}$ of the total thickness of the thin sections. Therefore, dissolution along the stylolites may account for only about $1 / 8$ of the total quartz cement in the Travis Peak. Furthermore, it is likely that the stylolites formed after the main phase of quartz cementation because stylolites appear to cut both detrital grains and quartz overgrowths.

Intergranular pressure solution is not commonly observed in Travis Peak sandstone either. Under cathodoluminescence, it can be seen that most interlocking contacts occur because cements grew together: interpenetration of detrital quartz grains is rare.

Using the technique of Clayton and Meyeda (1963), the oxygenisotopic composition of authigenic quartz was measured by choosing 33 samples that contain a wide range in percentage of quartz overgrowths (table 2). Samples were prepared by the method of Syers and others (1968) to remove all minerals except quartz. All samples were X-rayed to verify that non-quartz minerals had been destroyed. Detrital chert could not be removed, but samples were chosen to minimize the detrital chert volume. Oxygen-isotopic values for the whole samples were plotted against the ratio quartz overgrowth volume/total quartz volume (including detrital chert) as determined by point counts of samples taken adjacent to the samples used for geochemical analysis (fig. 17). A regression line based on all data has a correlation coefficient of 0.35 , and extrapolates to a 
Table 2. Isotopic analyses of quartz

$\begin{array}{llcl}\text { Sample } & \text { Depth below top } & \delta^{18} \mathrm{O} & \mathrm{F}^{*} \\ \text { depth (ft) } & \text { Travis Peak (ft) } & (\text { SMOW }) & (\%)\end{array}$

\begin{tabular}{|c|c|c|c|c|}
\hline BP & 8215.0 & 74 & 16.3 & 18.1 \\
\hline BP & 8372.9 & 231 & 15.1 & 23.1 \\
\hline BP & 8378.5 & 237 & 14.9 & 5.1 \\
\hline CGU & 6825.2 & 198 & 15.8 & 16.0 \\
\hline CGU & 6889.5 & 262 & 16.9 & 18.7 \\
\hline CGU & 7317.4 & 690 & 16.2 & 21.1 \\
\hline CGU & 7354.3 & 727 & 15.5 & 17.5 \\
\hline$D C$ & 6185.2 & 147 & 15.6 & 0.0 \\
\hline EW & 8190.1 & 113 & 14.2 & 2.2 \\
\hline MA & 5972.7 & 50 & 15.8 & 13.2 \\
\hline MA & 5974.0 & 52 & 14.1 & 0.0 \\
\hline MK & 8409.8 & 1275 & 17.2 & 32.0 \\
\hline MK & 8417.3 & 1283 & 14.1 & 13.8 \\
\hline MK & 8596.0 & 1462 & 15.3 & 27.2 \\
\hline MK & 8599.0 & 1465 & 15.2 & 15.3 \\
\hline MK & 8633.8 & 1499 & 15.4 & 29.0 \\
\hline PM & 8628.0 & 585 & 15.8 & 2.8 \\
\hline PM & 8662.3 & 619 & 17.3 & 18.4 \\
\hline PM & 8669.0 & 626 & 17.3 & 24.5 \\
\hline PM & 9202.0 & 1159 & 16.4 & 26.1 \\
\hline PM & 9948.2 & 1905 & 16.1 & 23.1 \\
\hline PM & 9956.0 & 1913 & 15.3 & 22.7 \\
\hline PM & 9959.9 & 1916 & 15.6 & 19.2 \\
\hline PM & 9985.1 & 1942 & 17.1 & 24.9 \\
\hline RD & 6429.1 & 39 & 17.0 & 3.1 \\
\hline SF & 9666.3 & 260 & 15.3 & 0.0 \\
\hline SF & 9750.7 & 344 & 15.6 & 24.9 \\
\hline $\mathrm{SF} 1$ & 10131.0 & 725 & 15.8 & 24.1 \\
\hline $\mathrm{SH}$ & 6843.7 & 13 & 17.3 & 14.6 \\
\hline $\mathrm{SH}$ & 7101.0 & 271 & 16.4 & 26.8 \\
\hline $\mathrm{SH}$ & 7101.2 & 271 & 16.8 & 22.6 \\
\hline WS & 7101.9 & 623 & 16.0 & 5.6 \\
\hline WS & 7124.2 & 646 & 17.3 & 11.0 \\
\hline
\end{tabular}




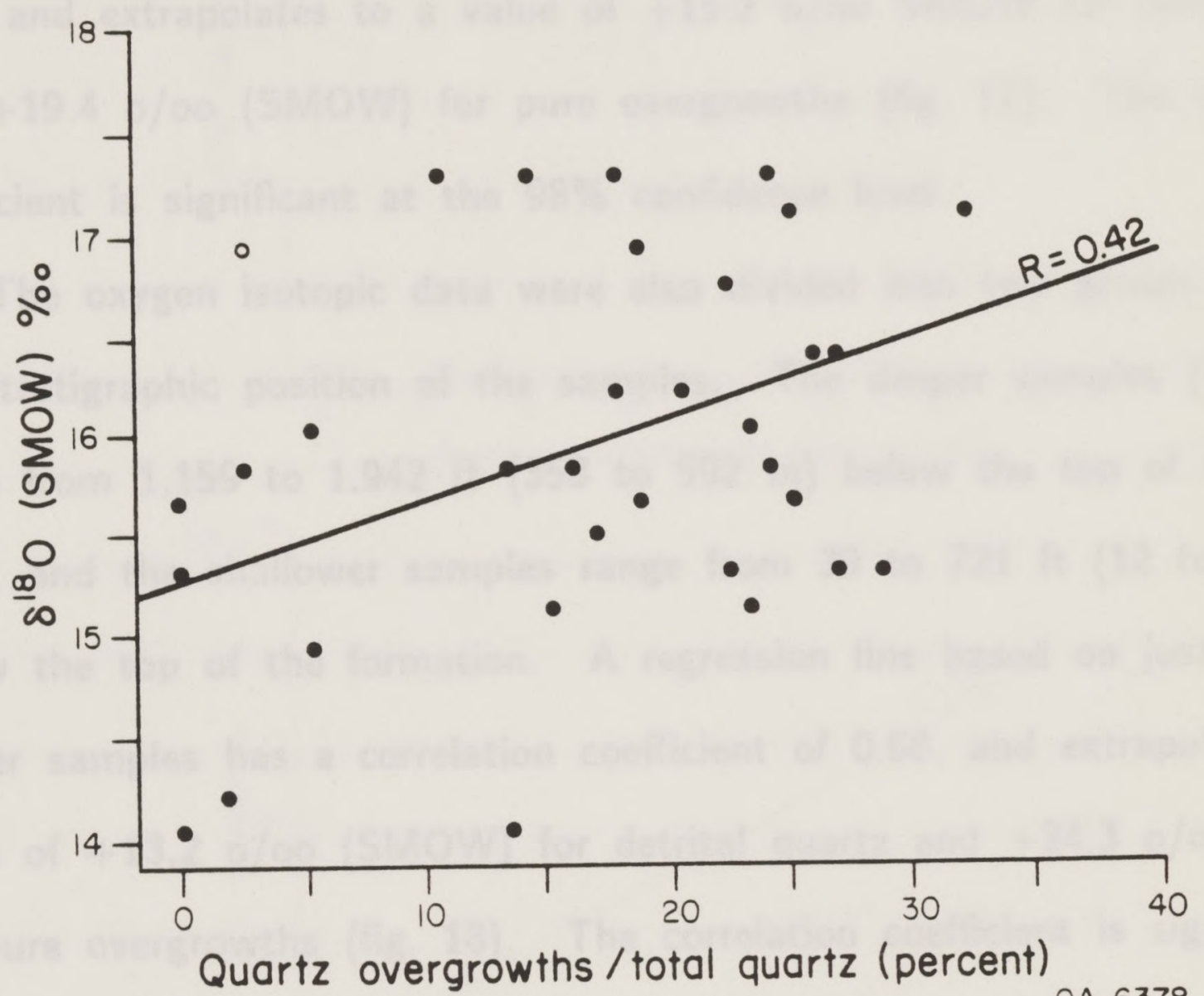

EXPLANATION

- Data point

- Data point omitted from
linear regression

Figure 17. Plot of $\delta^{18} \mathrm{O}$ of whole-rock quartz versus percent quartz overgrowths of total quartz. The regression line extrapolates to a value of $19.4 \% / 00$ (SMOW) for pure overgrowths. 
value of +15.4 \% $/ 00 \mathrm{SMOW}$ for detrital quartz and $+18.8 \%$ oo (SMOW) for pure overgrowths. If one apparently anomalous sample is omitted, the regression line based on the remaining data has a correlation coefficient of 0.42 , and extrapolates to a value of +15.2 o/oo SMOW for detrital quartz and +19.4 o/oo (SMOW) for pure overgrowths (fig. 17). The correlation coefficient is significant at the $98 \%$ confidence level.

The oxygen isotopic data were also divided into two groups based on the stratigraphic position of the samples. The deeper samples (table 2) range from 1.159 to $1.942 \mathrm{ft}$ ( 353 to $592 \mathrm{~m}$ ) below the top of the Travis Peak, and the shallower samples range from 39 to $721 \mathrm{ft}(12$ to $220 \mathrm{~m})$ below the top of the formation. A regression line based on just the deeper samples has a correlation coefficient of 0.68 , and extrapolates to a value of $+13.2 \% / 00(\mathrm{SMOW})$ for detrital quartz and $+24.3 \% / 00$ (SMOW) for pure overgrowths (fig. 18). The correlation coefficient is significant at the $95 \%$ confidence level. The regression line for the shallower samples has a correlation coefficient of 0.51 , and extrapolates to a value of +15.2 for detrital quartz and +20.3 for pure overgrowths (fig. 18). The correlation coefficient for the shallower samples is significant at the $98 \%$ confidence level.

The range of volumes of quartz overgrowths in the deeper samples is more limited than in the shallower samples or the total population (figs. 17. 18): the differences among the three samples in the mean value of quartz overgrowths results in different values for the $y$-intercepts of the three regression lines. For this reason, the extrapolated value of 

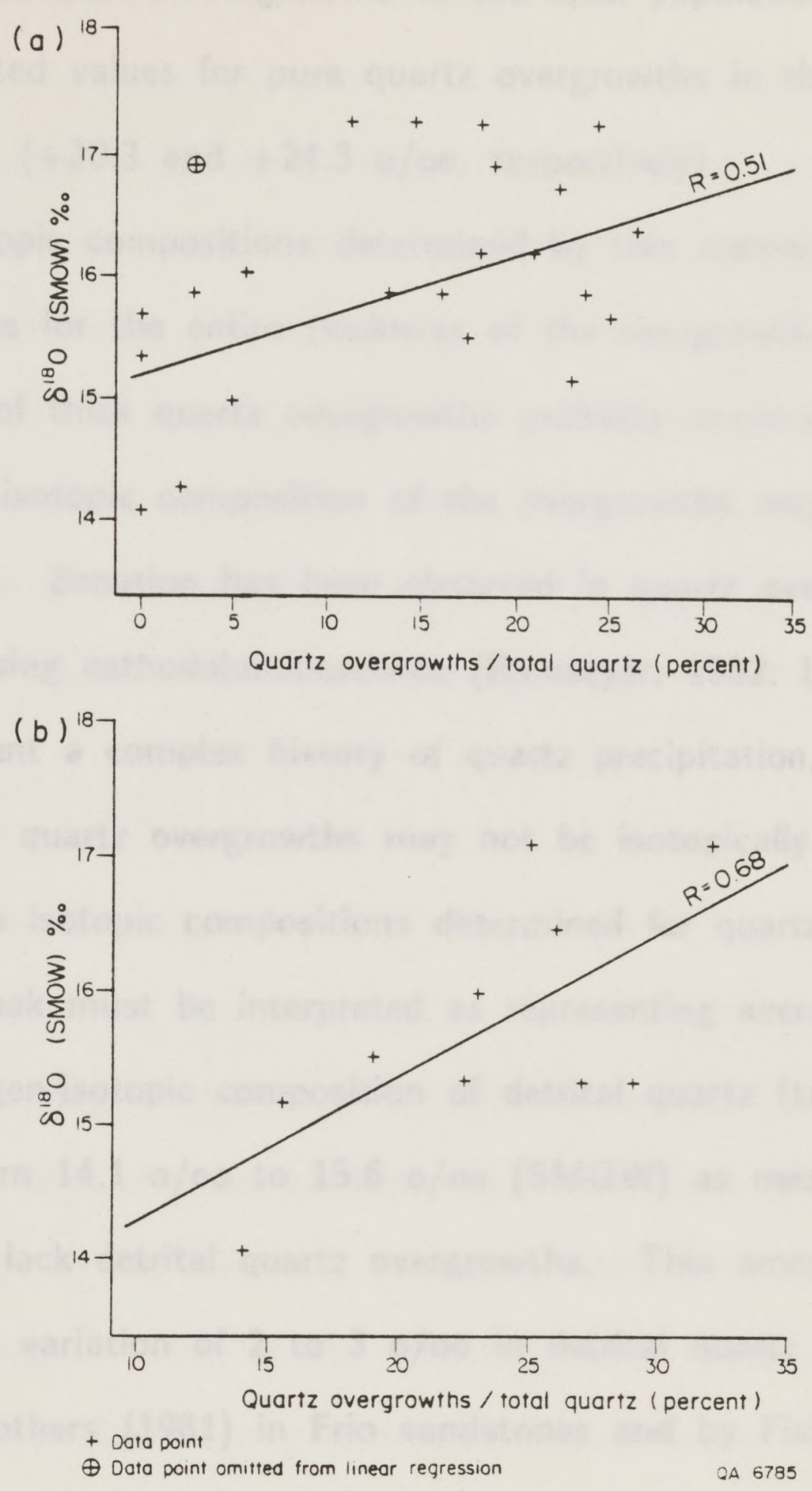

Figure 18. Plots of $\delta^{18} \mathrm{O}$ of whole-rock quartz versus percent quartz overgrowths of total quartz for a) samples from deeper in the formation. and b) samples from the upper part of the formation. The regression line for deeper samples extrapolates to a value of $24.3 \% / 00$ (SMOW), and the regression line for shallower samples extrapolates to a value of $20.3 \% / 00$ (SMOW) for pure overgrowths. 
o/oo for $100 \%$ quartz overgrowths in the total population is lower than the extrapolated values for pure quartz overgrowths in the shallow and deep samples $(+20.3$ and +24.3 o/oo, respectively).

The isotopic compositions determined by this method provide average isotopic values for the entire thickness of the overgrowths. However, the precipitation of thick quartz overgrowths probably occurred over a period of time. so the isotopic composition of the overgrowths may not be homogeneous. Zonation has been observed in quartz overgrowths in other sandstones using cathodoluminescence (Ramseyer, 1982: Land, 1984); the zones document a complex history of quartz precipitation, which further suggests that quartz overgrowths may not be isotopically homogeneous. Therefore, the isotopic compositions determined for quartz overgrowths in the Travis Peak must be interpreted as representing average values.

The oxygen-isotopic composition of detrital quartz (table 2; figs. 17 . 18) varies from $14.1 \% / 00$ to $15.6 \% / 00(\mathrm{SMOW})$ as measured in three samples that lack detrital quartz overgrowths. This amount of variation is similar to the variation of 2 to $3 \% / 00$ in detrital quartz observed by Milliken and others (1981) in Frio sandstones and by Fisher and Land (1986) in Wilcox sandstones. However, the detrital quartz in the Travis Peak is about $3 \% / 00$ heavier than detrital quartz in those Tertiary formations.

The estimated $\delta^{18} \mathrm{O}$ values of 19.4 to 24.3 \%/oo (SMOW) for Travis Peak quartz overgrowths are similar to the $\delta^{18} \mathrm{O}$ value of $+18.2 \mathrm{o} / \mathrm{oo}$ calculated for quartz overgrowths in Jurassic Norphlet sandstone in the 
Gulf Coast (McBride and others, in preparation) and the values of +14 to +17 o/oo for quartz overgrowths in Cretaceous Tuscaloosa sandstone (equivalent to the Woodbine in Texas; fig. 4) from Louisiana and Mississippi (Sucheki. 1983). The Travis Peak isotopic values are somewhat lighter than isotopic values of quartz overgrowths in Eocene Wilcox sandstone of South-Central Texas, which vary from +22.5 to +31 ○/oo (SMOW) (Fisher and Land, 1986). Quartz overgrowths in Oligocene Frio sandstone of the Gulf Coast are even heavier, with an average $\delta^{18} \mathrm{O}$ composition of about +31 o/oo (SMOW) (Milliken and others, 1981: Land, 1984).

Authigenic Clay Minerals

Authigenic clays that have been identified in the Travis Peak sandstone are illite, chlorite, kaolinite, and mixed-layer illite-smectite. Illite and chlorite are by far the most abundant authigenic clays, with a combined average of $3.0 \%$ of the sandstone based on point counts. although some of that volume is actually microporosity. In thin sections. microporosity cannot be distinguished from clay flakes, but by SEM it can be seen that abundant porosity occurs between individual clay flakes (fig. 19).

Kaolinite was observed in only a few samples. In the Amoco Kangerga No. 1-C core, authigenic kaolinite occurs in primary and secondary pores and with remnants of partly dissolved feldspar grains. 


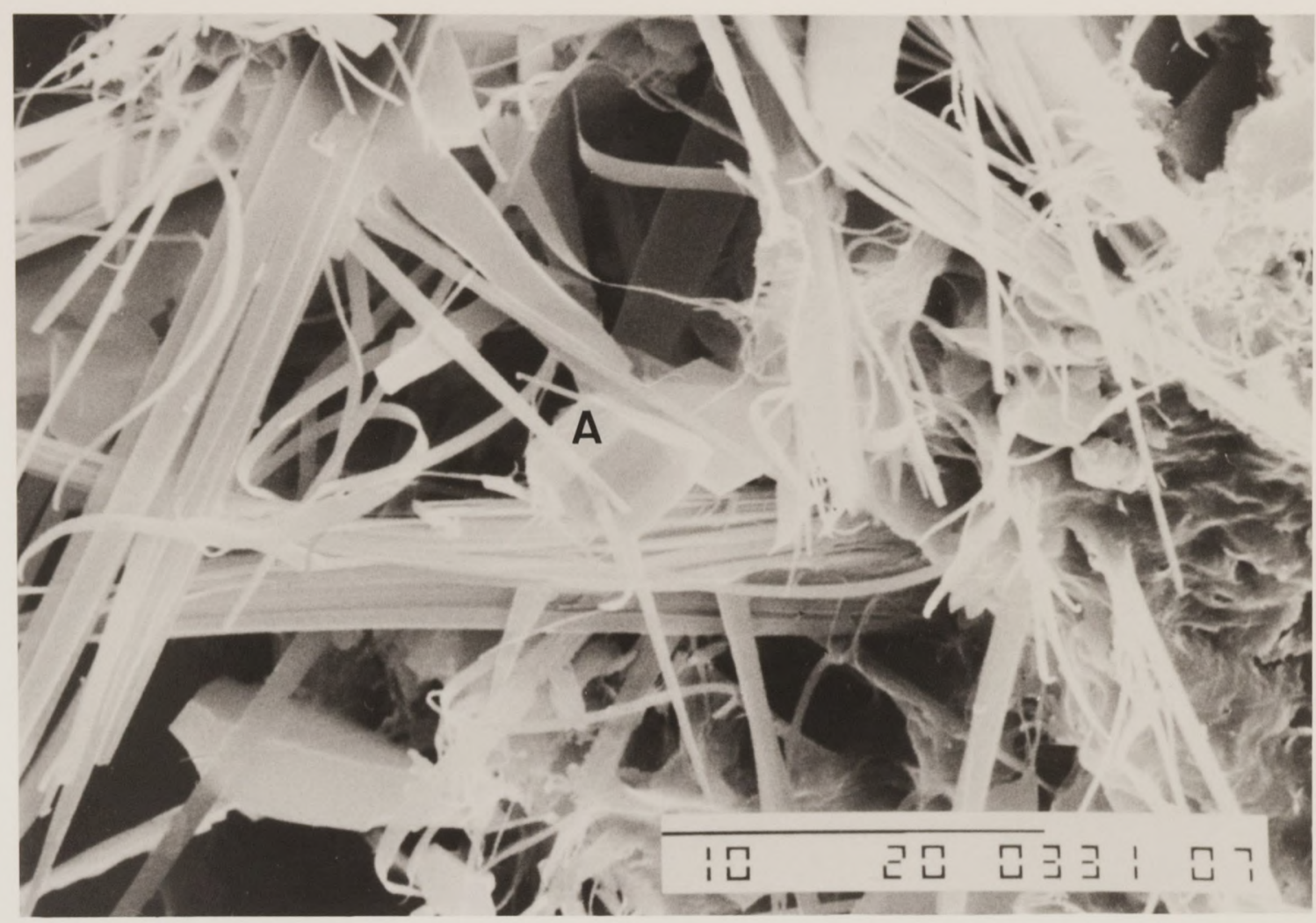

Figure 19. SEM photograph of authigenic illite fibers and albite (A). with abundant microporosity from a depth of $9.941 .1 \mathrm{ft}(3.030 .0 \mathrm{~m})$ in the Prairie Mast No. A-1 core. Bar length is $10 \mu \mathrm{m}$; magnification is $3500 \mathrm{x}$. 
Most kaolinite appears to have precipitated after quartz cement, but some kaolinite is engulfed in quartz overgrowths, suggesting that although quartz cementation generally preceeded kaolinite precipitation, there was some overlap in their precipitation. Kaolinite is most abundant in samples from the Arkla Scott No. 5 core, where it occurs in both primary and secondary pores, including secondary pores within leached orthoclase grains. In the Arkla Scott No. 5 core, kaolinite appears to have precipitated after quartz overgrowths.

Minor amounts of mixed-layer illite-smectite with approximately $5 \%$ smectite layers were identified by X-ray diffraction in matrix-free sandstone in the Ashland S.F.O.T. No. 1 at depths of 9,665 to $10.151 \mathrm{ft}(2.946$ to $3.094 \mathrm{~m}$ ) and Prairie Mast No. 1-A sandstone at a depth of $8.667 \mathrm{ft}$ (2.642 m) (David K. Davies and Associates. 1985a and b).

Some of the illite in Travis Peak sandstone occurs as rims of tangentially oriented crystals that coat detrital grains. In most samples the illite rims are thin. and quartz cement precipitated over them, so that the illite now forms distinct boundaries between detrital grains and overgrowths. Where the illite rims are sufficiently thick, they prevented nucleation of quartz overgrowths. An extreme example of this occurs in a sandstone at 7.442 to $7.462 \mathrm{ft}(2.268$ to $2.274 \mathrm{~m})$ in the Arkla Scott No. 5 well (fig. 20). This is a crossbedded and planar laminated fluvial sandstone near the base of the Travis Peak; it is overlain by muddy sandstone and red mudstone with mottled soil texture and root traces. The upper part of the sandstone $(7.442$ to $7.453 \mathrm{ft}: 2.268$ to $2.272 \mathrm{~m})$ is 


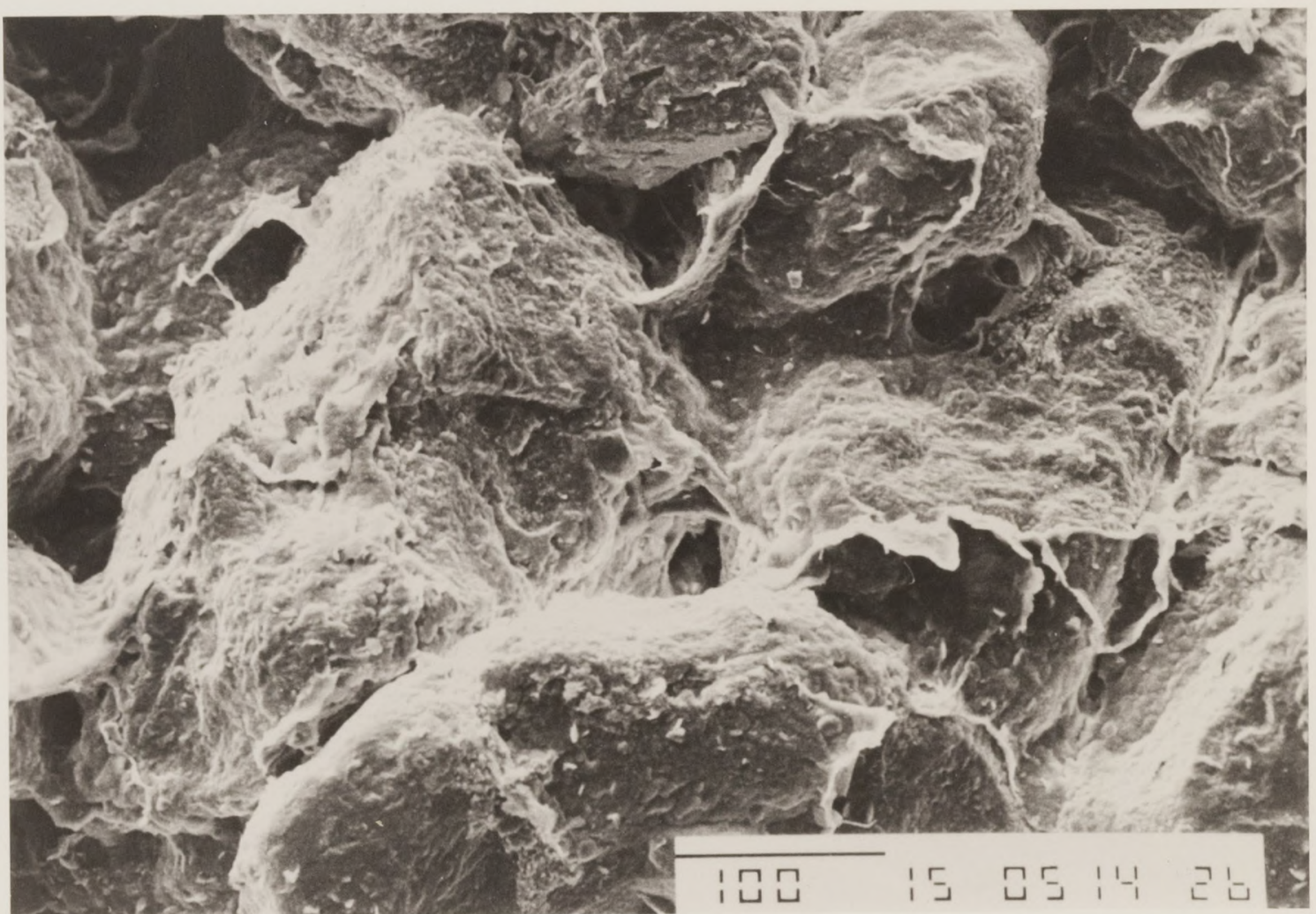

Figure 20. SEM photograph of thick illite cutans coating detrital grains from a depth of $7.451 .0 \mathrm{ft}(2.271 .1 \mathrm{~m})$ in the Arkla Scott No. 5 core. Bar length is $100 \mu \mathrm{m}$; magnification is $500 \mathrm{x}$. 
porous and poorly indurated, whereas the lower part $(7.453$ to $7.462 \mathrm{ft}$ : 2.272 to $2.274 \mathrm{~m}$ ) is well indurated. Samples from the upper interval contain as much as $14 \%$ by volume clay rims around detrital grains (fig. 20 ), and volumes of quartz overgrowths are as low as $0.5 \%$. The rims are birefringent, but EDX analysis of SEM samples indicates that some chlorite occurs in the rims as well as illite. The deeper part of this sandstone has much thinner clay rims (1 to $3 \%$ ) and correspondingly more abundant quartz cement (15\%). Although some of the illite and chlorite in the clay cutans may be authigenic, the depositional setting of this sandstone and the distribution of cutans within the sandstone suggest that most of the clay entered the sandstone by mechanical infiltration from the soil above. This process is characteristic of the vadose zone, in which downward percolating rain or floodwater carries clay-sized material that is deposited tangentially to detrital sand grains when the water evaporates or diffuses into capillaries (Brewer, 1964; Molenaar, 1986).

True authigenic illite occurs as delicate fibers (fig.19) inside both primary and secondary pores. Illite is commonly associated with altered and leached feldspars and thus was a relatively late diagenetic phase compared to the precipitation of quartz overgrowths.

Authigenic chlorite (fig. 21) occurs as individual flakes and rosettes inside both primary and secondary pores, and, like illite, is commonly associated with altered feldspars. No difference in the timing of precipitation of illite and chlorite could be distinguished by SEM or thin section petrography. Both illite and chlorite cements in the Travis Peak 


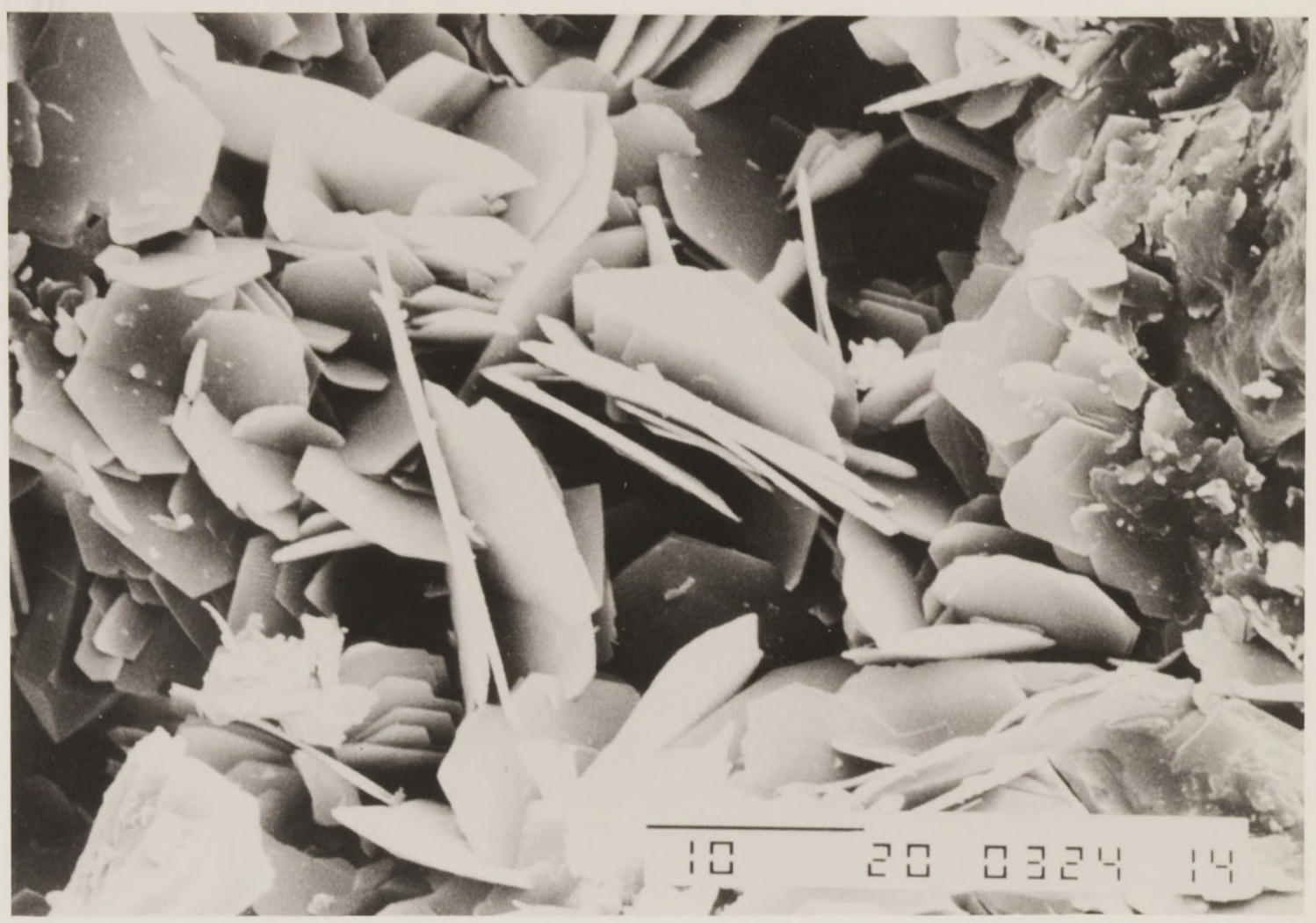

Figure 21. SEM photograph of authigenic chlorite from a depth of 8.229.0 $\mathrm{ft}(2.508 .2 \mathrm{~m})$ in the Stallworth Renfro No. 2 core. Bar length is $10 \mu \mathrm{m}$ : magnification is $2000 x$. 
are iron rich as indicated by EDX.

\section{Authigenic Carbonate Cements}

Dolomite, ankerite, and calcite cement all occur in Travis Peak sandstones, but only dolomite and ankerite are common. Calcite cement was observed only in sandstones adjacent to limestone beds near the top of the formation. The average composition of five calcite cements is $\left(\mathrm{Ca}_{0.94} \mathrm{Mg}_{0.021} \mathrm{Fe}_{0.028} \mathrm{Mn}_{0.0007}\right) \mathrm{CO}_{3}$. In most samples that contain

calcite cement, the calcite appears to be the first cement that precipitated. and it prevented later nucleation of quartz cement.

The average volume of dolomite cement is $1.5 \%(\sigma=4.5 \%)$, but a few samples contain abundant dolomite. Three samples contain more than $25 \%$ dolomite pore-filling cement and framework-grain replacement.

Dolomite rhombs commonly precipitated within detrital clay matrix or clay clasts, and from petrographic evidence they appear to have precipitated early in the diagenetic history of the Travis Peak sandstones. Dolomite is most abundant in the delta-fringe facies in the upper part of the Travis Peak (fig. 22); samples from the deeper, fluvial sections of the Travis Peak contain little or no dolomite. 


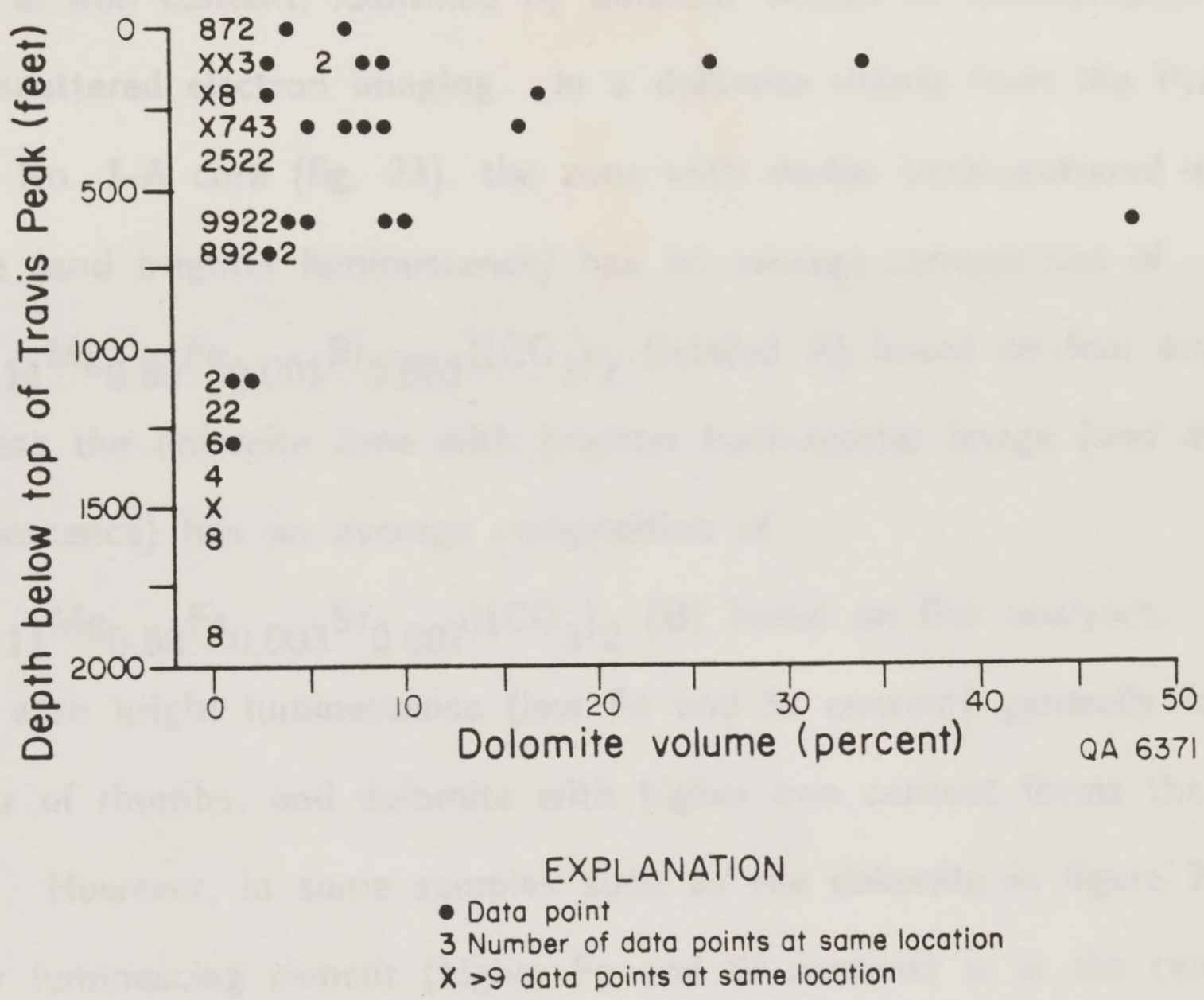

Figure 22. Dolomite cement volume decreases with depth below the top of the Travis Peak. 


\section{Major element composition}

Many of the dolomite rhombs have at least two distinct zones that differ in iron content, identified by different shades of luminescence and back-scattered electron imaging. In a dolomite rhomb from the Prairie Mast No. 1-A core (fig. 23), the zone with darker back-scattered electron image (and brighter luminescence) has an average composition of $\left(\mathrm{Ca}_{1.11} \mathrm{Mg}_{0.89} \mathrm{Fe}_{0.001} \mathrm{Sr}_{0.001}\right)\left(\mathrm{CO}_{3}\right)_{2}$ (labeled $\left.\mathrm{A}\right)$ based on four analyses. whereas the dolomite zone with brighter back-scatter image (and duller luminescence) has an average composition of $\left(\mathrm{Ca}_{1.11} \mathrm{Mg}_{0.88} \mathrm{Fe}_{0.003} \mathrm{Sr}_{0.007}\right)\left(\mathrm{CO}_{3}\right)_{2}(\mathrm{~B})$ based on five analyses. The zone with bright luminescence (low $\mathrm{Fe}$ and $\mathrm{Sr}$ content) generally forms the center of rhombs, and dolomite with higher iron content forms the outer zone. However, in some samples such as the dolomite in figure 23. the duller luminescing cement (higher $\mathrm{Fe}$ and $\mathrm{Sr}$ content) is in the center, and it is rimmed by iron-poor, brighter luminescing cement that appears to have been corroded and replaced by the more iron-rich dolomite cement. This textural evidence suggests that an iron-poor phase was the first dolomite to precipitate, and the composition evolved to a more iron-rich dolomite as precipitation and replacement continued. In most cements the earliest formed dolomite was simply surrounded by the later, more iron-rich dolomite, but in some cements the earliest dolomite was dissolved and replaced by iron-rich dolomite. In addition, dolomite rhombs are commonly rimmed by ankerite (fig. 23) and may be partially replaced by ankerite 


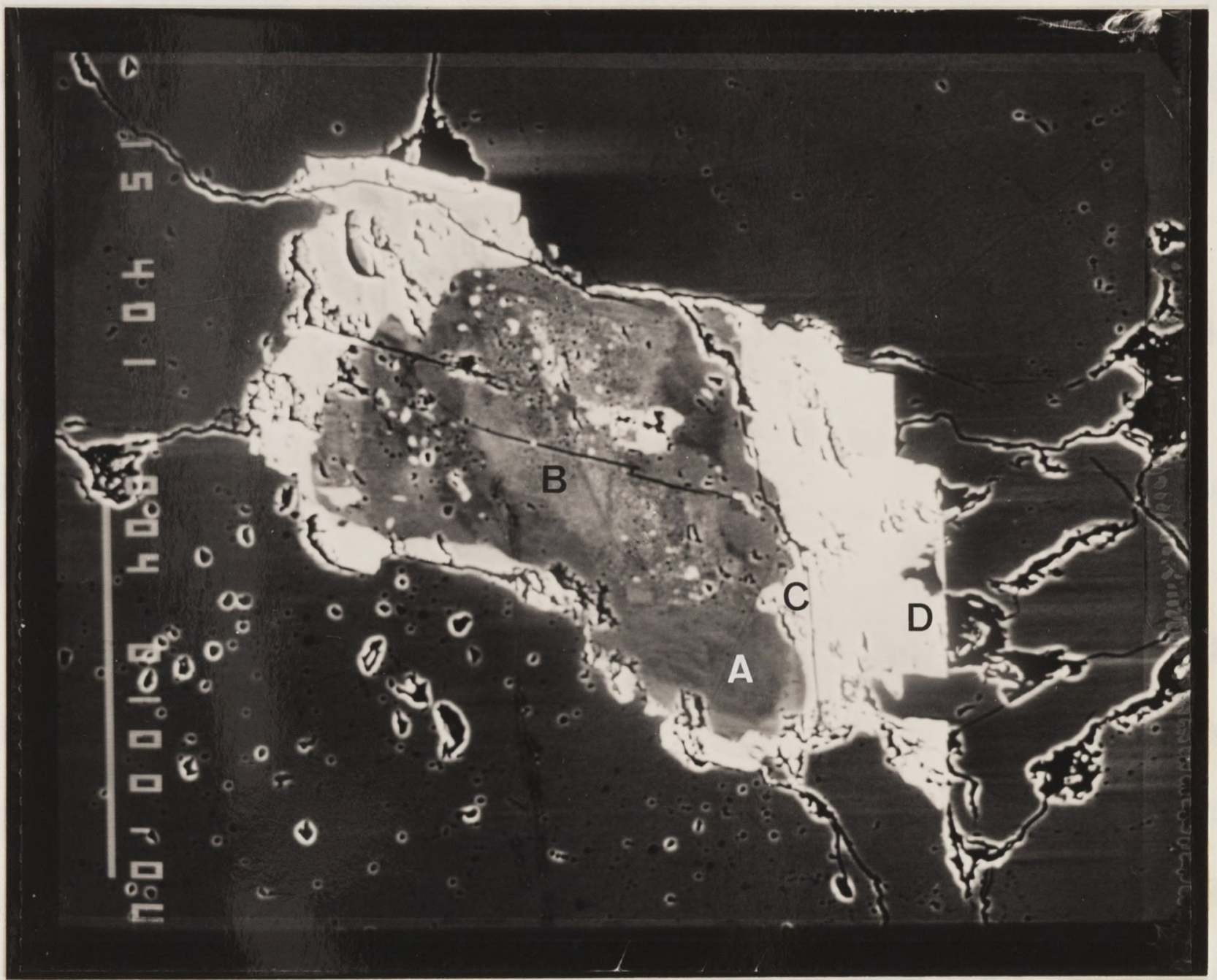

Figure 23. Backscatter electron image of dolomite (darker center) and ankerite (light) cement. Outside margin of dolomite appears corroded. From a depth of $9.230 .2 \mathrm{ft}(2.813 .4 \mathrm{~m})$ in the Prairie Mast No. A-1 core. Bar length is $100 \mu \mathrm{m}$. See text for composition of zones A. B. C. and D. 
along cleavage traces and around the outer edges of the dolomite.

As in the case of dolomite cement, ankerite is most abundant in the marine-associated delta-fringe facies near the top of the Travis Peak Formation, and its abundance decreases with depth into the fluvial section (fig. 24). The mean volume of ankerite is $2.7 \%(\sigma=5.3 \%)$, but a few samples contain abundant ankerite. Five samples contain more than $15 \%$ ankerite pore-filling cement and framework-grain replacement. Ankerite cement is commonly zoned, with the most iron-rich ankerite at the edges of rhombs. The ankerite that rims dolomite in the example from the Prairie Mast No. 1-A core (fig. 23) varies in composition from $\left(\mathrm{Ca}_{1.08} \mathrm{Mg}_{0.77} \mathrm{Fe}_{0.15}\right)\left(\mathrm{CO}_{3}\right)_{2}$ (C) to $\left(\mathrm{Ca}_{1.06} \mathrm{Mg}_{0.75} \mathrm{Fe}_{0.19}\right)\left(\mathrm{CO}_{3}\right)_{2}$ (D). For all ankerite cements, the composition ranges from $\left(\mathrm{Ca}_{1.06} \mathrm{Mg}_{0.88} \mathrm{Fe}_{0.02} \mathrm{Mn}_{0.03}\right)\left(\mathrm{CO}_{3}\right)_{2}$, which is really a ferroan dolomite, to $\left(\mathrm{Ca}_{1.10} \mathrm{Mg}_{0.44} \mathrm{Fe}_{0.43} \mathrm{Mn}_{0.03}\right)\left(\mathrm{CO}_{3}\right)_{2}$ (fig. 25).

In most individual cement masses that contain both dolomite and ankerite, it is possible to distinguish two or more distinct zones in the dolomite by backscattered electron imaging or luminescence; an additional zone of ankerite cement can also be clearly differentiated from the dolomite by these methods (fig. 23). When the chemical data from one individual cement patch are plotted, the dolomite zones, which can clearly be distinguished by visual techniques, tend to form one continuous chemical trend, not two or more distinct compositional areas. The ankerite from the same individual cement mass generally plots as a distinct chemical phase from the dolomite. However, when microprobe data from all 


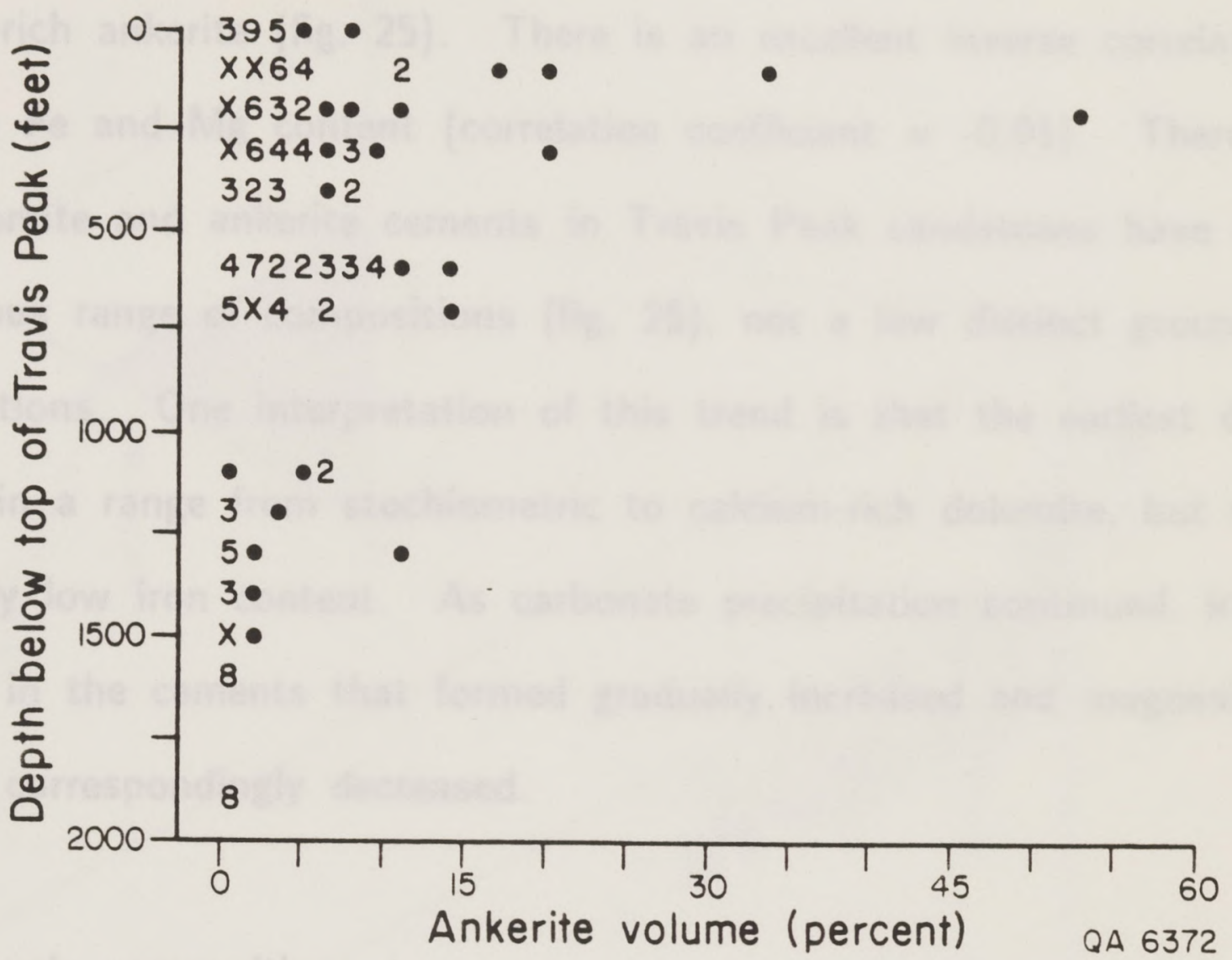

\footnotetext{
- Data point

3 Number of data points at same location

$X>9$ data points at same location
}

EXPLANATION

Figure 24. Ankerite cement volume decreases with depth below the top of the Travis Peak. 
carbonate cements in the Travis Peak are combined in a plot of $\mathrm{Ca} / \mathrm{Mg}$ vs $\mathrm{Fe}$, there is one continuous trend from essentially stochiometric dolomite to calcium-rich ankerite (fig. 25). There is an excellent inverse correlation between $\mathrm{Fe}$ and $\mathrm{Mg}$ content (correlation coefficient $=-0.91$ ). Therefore, the dolomite and ankerite cements in Travis Peak sandstones have a continuous range of compositions (fig. 25), not a few distinct groups of compositions. One interpretation of this trend is that the earliest dolomite formed in a range from stochiometric to calcium-rich dolomite, but with uniformly low iron content. As carbonate precipitation continued, iron content in the cements that formed gradually increased and magnesium content correspondingly decreased.

\section{Isotopic composition}

Carbon and oxygen isotopic composition of dolomite and ankerite cements were determined for 16 samples with good stratigraphic and geographic range within the study area (fig. 26; table 3). It was possible to choose samples that contain only ankerite cement, but it was not possible to sample only dolomite because all samples that contain dolomite also contain ankerite. Therefore, it was necessary to calculate the carbon and oxygen isotopic composition of pure dolomite based on the relative volume of dolomite and ankerite in each sample as determined by thin section. This was an imprecise method because the sample that was point counted, although adjacent to the analyzed sample, may not have the 


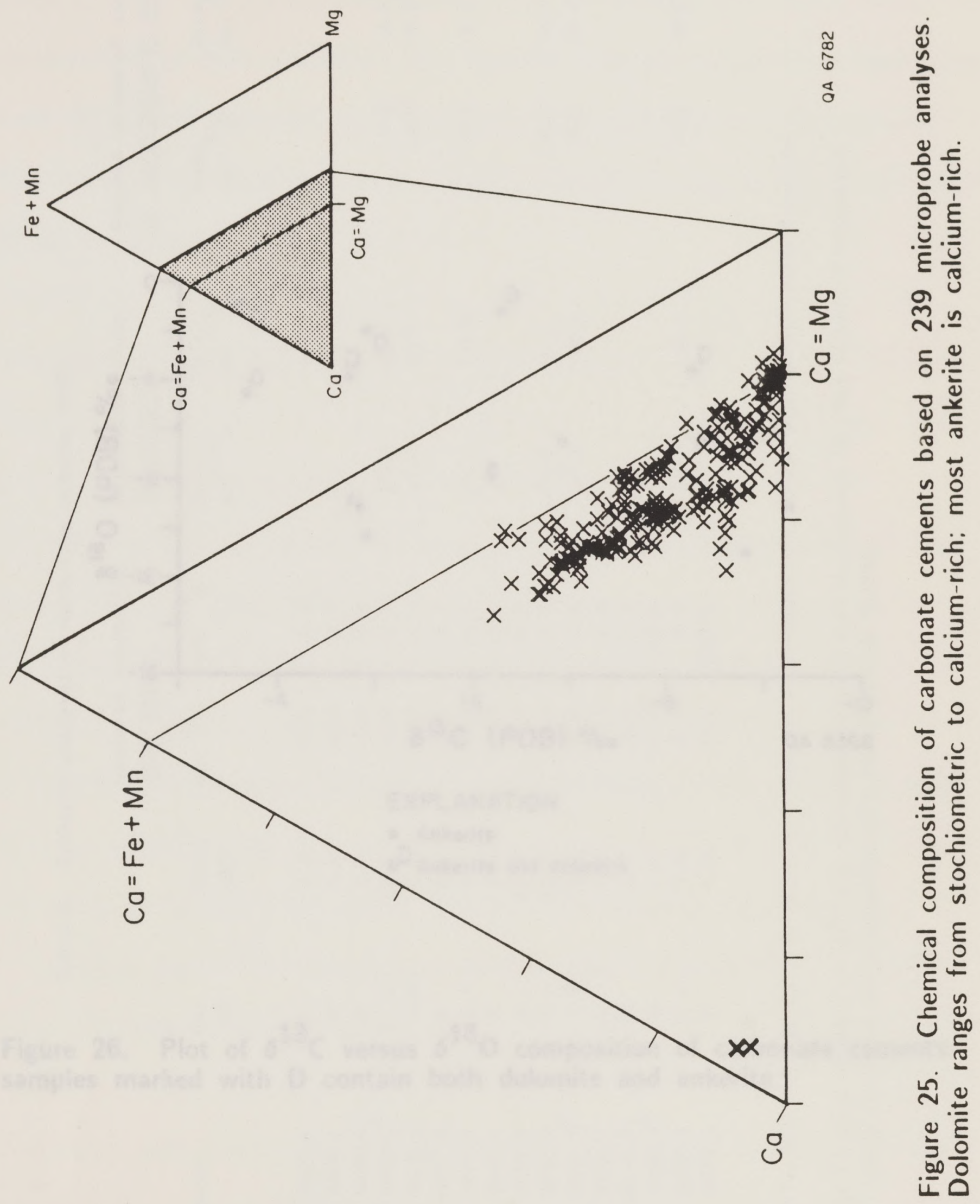




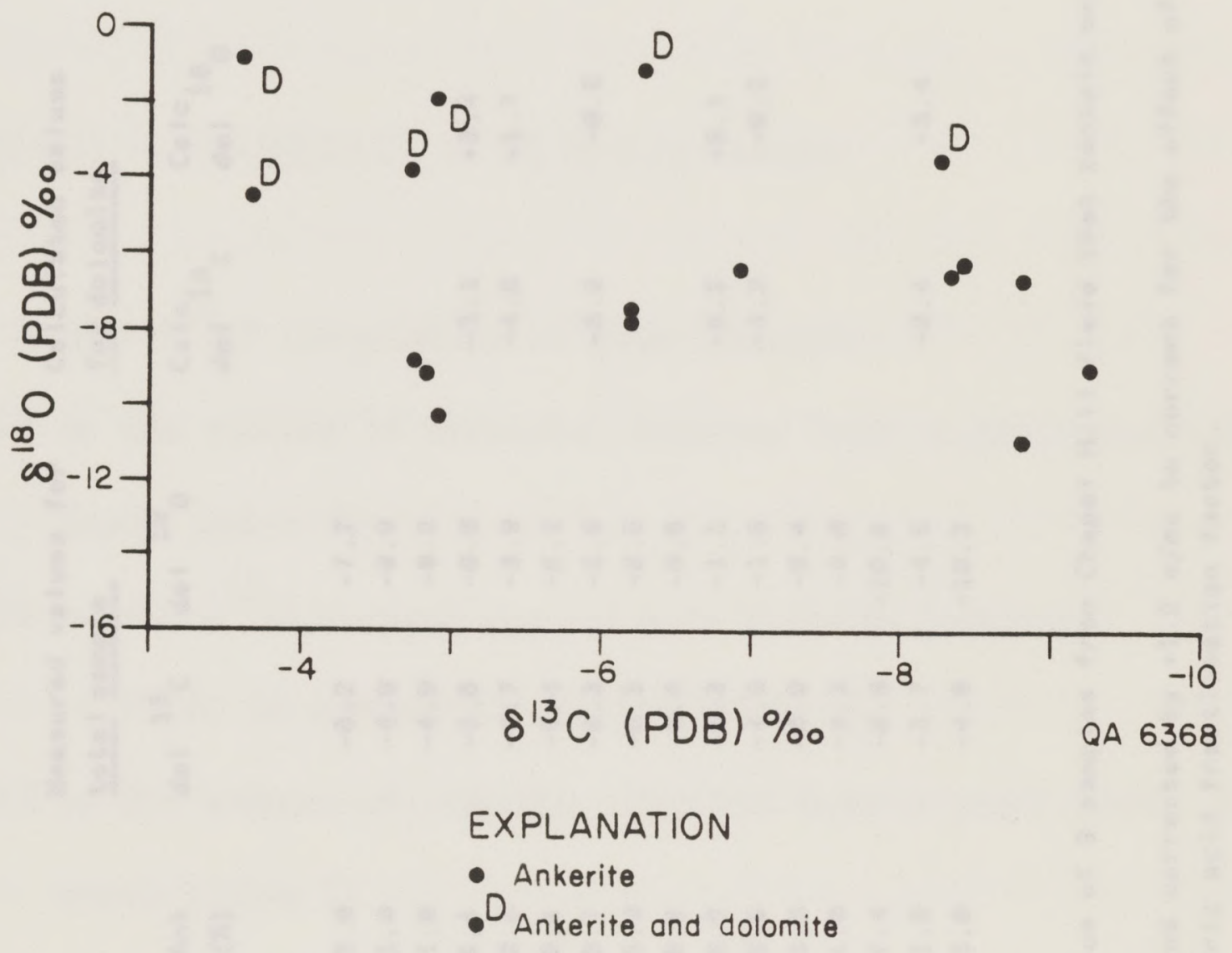

Figure 26. Plot of $\delta^{13} \mathrm{C}$ versus $\delta^{18} \mathrm{O}$ composition of carbonate cements: samples marked with $\mathrm{D}$ contain both dolomite and ankerite. 

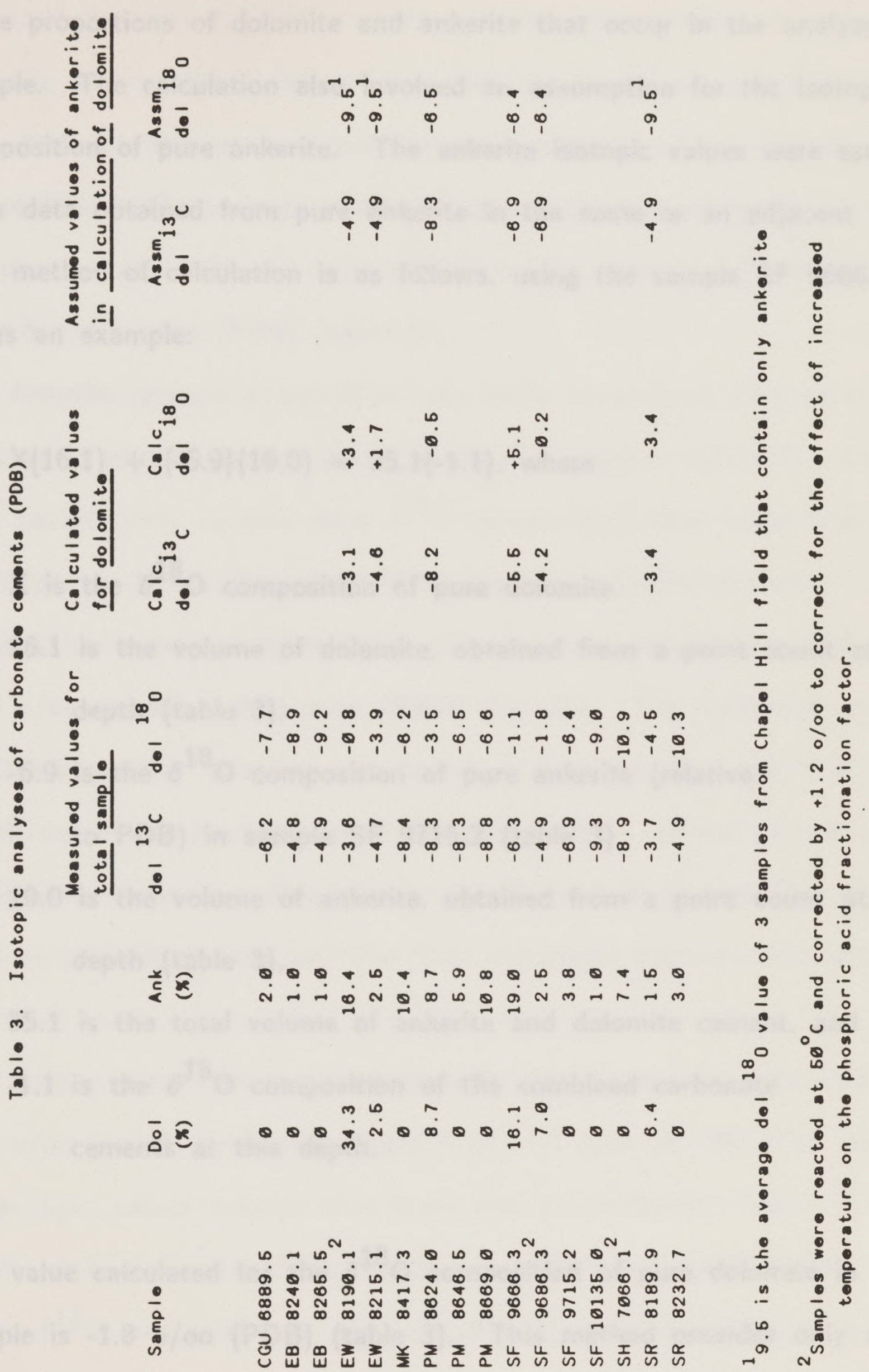
same proportions of dolomite and ankerite that occur in the analyzed sample. The calculation also involved an assumption for the isotopic composition of pure ankerite. The ankerite isotopic values were estimated from data obtained from pure ankerite in the same or an adjacent well. The method of calculation is as follows, using the sample SF 9666.3 (table 3) as an example:

$$
X(16.1)+(-6.9)(19.0)=35.1(-1.1), \text { where }
$$

$X$ is the $\delta^{18} \mathrm{O}$ composition of pure dolomite,

16.1 is the volume of dolomite, obtained from a point count at this depth (table 3).

-6.9 is the $\delta^{18} \mathrm{O}$ composition of pure ankerite (relative to PDB) in sample SF 9715.2 (table 3).

19.0 is the volume of ankerite, obtained from a point count at this depth (table 3).

35.1 is the total volume of ankerite and dolomite cement, and

-1.1 is the $\delta^{18} \mathrm{O}$ composition of the combined carbonate cements at this depth.

The value calculated for the $\delta^{18} \mathrm{O}$ composition of pure dolomite in this sample is -1.8 o/oo (PDB) (table 3 ). This method provides only a rough estimate because of the uncertainty of the actual dolomite/ankerite proportions in the isotopic sample. In addition, the dolomite is known to 
be zoned, but this calculation gives just one average value to represent all dolomite in a sample. Nevertheless, because it was not possible to isolate pure dolomite, this method provides some estimate of the dolomite isotopic composition. The average of all calculated values for dolomite is a $\delta^{18} \mathrm{O}$ composition of $+1.01 \pm 3 \% / o o(\mathrm{PDB})$ and an average $\delta^{13} \mathrm{C}$ composition of $-4.8 \pm 1.9$ o/oo (PDB) (table 3).

Ankerite isotopic composition was easier to evaluate because it was possible to obtain samples that contain only ankerite (table 3). Samples that contain only ankerite have $\delta^{18} \mathrm{O}$ compositions that range from $-6.2 \pm$ 0.1 o/oo to $-10.9 \pm 0.1$ o/oo (PDB) (fig. 26). Carbon isotopic composition averages $-6.9 \circ / 00( \pm 1.8 \% / 00)$ and ranges from $-4.8 \pm$ 0.03 \%/oo to $-9.3 \pm 0.04$ \% 00 (PBD) (fig. 26). The measured variation in $\delta^{18} \mathrm{O}$ composition is believed to be real and reflects changing fluid conditions during precipitation of ankerite cement. Zoning of iron content in ankerite cement provides additional evidence that precipitation occurred over an interval of time and that fluid conditions evolved chemically during this time.

Carbon isotopic composition in both ankerite and dolomite averages $-6.4 \circ / 00( \pm 1.9 \circ / \circ 0)$ and ranges from $-3.6 \circ / 00$ to $-9.3 \circ / \circ 0$ (table 3). These light values indicate that there was a contribution from ${ }^{13} \mathrm{C}$-depleted carbon derived from oxidation or decarboxylation of organic matter, which has a $\delta^{13} \mathrm{C}$ composition of approximately $-23 \% / 00$. but that most of the carbon evidently was derived from skeletal carbon. Modern carbonate sediment has $\delta^{13} \mathrm{C}$ values that range from +4 to $-2 \% / 00$ (Land, 1980). 
The average $\delta^{13} \mathrm{C}$ value of the ankerite cement is about $2 \%$ oo lighter than the average for the dolomite cement, indicating the ankerite probably incorporated more organic carbon than did the dolomite.

Strontium isotopic ratios were measured in five samples (table 4) with varying proportions of ankerite and dolomite cement. Two samples contain ankerite only, but no samples were available that contain only dolomite cement (table 4). The samples that contain only ankerite cement (MK 8417 and PM 8669 ) have ${ }^{87} \mathrm{Sr} /{ }^{86} \mathrm{Sr}$ values of 0.70989 and 0.70996 ; these high ratios indicate that radiogenic strontium was incorporated into the ankerite cement. It is difficult, however, to determine the strontium ratio for pure dolomite from these data. Two of the three samples that contain both ankerite and dolomite cements (SF 9686 and SR 8189) have ${ }^{87} \mathrm{Sr} /{ }^{86} \mathrm{Sr}$ values that are very close to the values measured in ankerite alone, 0.70996 and 0.70959 , respectively (table 4). The third sample. EW 8190, has a significantly lower ratio of .70807 . If only the data from EW 8190. MK 8417, and PM 8669 are used, the strontium ratio for pure dolomite projects to a value of .70718 , which is very close to the ${ }^{87} \mathrm{Sr} /{ }^{86} \mathrm{Sr}$ ratio of Early Cretaceous seawater (Burke and others, 1980). Therefore, the strontium data support petrographic observations that at least some dolomite cement in Travis Peak sandstones precipitated early in the diagenetic history. The dolomite cement either precipitated from Early Cretaceous seawater shortly after deposition, or it precipitated later from remobilized Early Cretaceous skeletal carbonate. In either case, at least some of the dolomite must have precipitated before significant amounts of 
Table 4. Strontium isotopic analyses

$\begin{array}{lccc}\begin{array}{c}\text { Sample } \\ \text { depth (ft) }\end{array} & { }^{87} \mathrm{Sr} /{ }^{86} \mathrm{Sr} & \text { Ank (\%) } & \text { Carb (\%) }{ }^{2} \\ \text { EW 8190.1 } & 0.70807 & 32.3 & 50.7 \\ \text { MK 8417.3 } & 0.70989 & 100.0 & 10.4 \\ \text { PM 8669.0 } & 0.70996 & 100.0 & 10.8 \\ \text { SF } 9686.3 & 0.70996 & 26.3 & 9.5 \\ \text { SR 8189.9 } & 0.70959 & 19.0 & 7.9\end{array}$

1 Ank $(\%)=$ percent of total carbonate cement that is ankerite.

Carb $(\%)=$ percent of rock that is carbonate cement. 
radiogenic strontium were available, whereas some precipitated (by replacement) when radiogenic strontium was available to the pore fluids. Ankerite was a later cement that formed after radiogenic strontium had been released into pore fluids, probably by feldspar albitization or dissolution.

Feldspar

Albite overgrowths on plagioclase grains are present in most samples. both as external overgrowths and as internal overgrowths within partially dissolved grains. Areas that could be identified as overgrowths consistently had compositions of very pure albite, approximately $\mathrm{An}_{0.001}$. As mentioned earlier, the precipitation of albite overgrowths is an integral part of the albitization process. Many of the fresh, albitized grains with chessboard twinning have been completely infilled by internal albite cement that can no longer be identified as overgrowths.

Other Authigenic Minerals

Pyrite, barite, and anhydrite are the other authigenic mineral phases that are present in the Travis Peak. Minor anhydrite cement was identified in thin sections from 10 of the 18 wells: most samples contain either no anhydrite or less than $1 \%$. but one sample from the Prairie Mast No. 1-A core $(9,212 \mathrm{ft} ; 2,808 \mathrm{~m})$ has $9 \%$ anhydrite cement. Anhydrite 
replaces both framework grains and cements; petrographic evidence indicates it precipitated after quartz overgrowths and probably after ankerite. Anhydrite nodules and fracture fillings were observed in core from the Arkla Scott No. 5 well. Both anhydrite occurrences are interpreted as late. diagenetic features.

Barite is less abundant than anhydrite, with a maximum volume of $0.5 \%$ in a few samples. In most thin sections, no barite cement was observed. Bladed barite crystals occur in secondary pores, indicating that they were a relatively late-stage cement.

Pyrite is present in small amounts in most cores, but it is more abundant in wells that contain coalified wood fragments. Pyrite nodules in the Prairie Mast No. 1-A core extensively replace framework grains.

Solid Hydrocarbons

Solid hydrocarbon accumulations that line pores in some sandstones were observed in all cores except the Amoco Kangerga No. 1-C. Because it was emplaced in the sandstones during burial diagenesis, this material is considered to be a cement. It is interpreted to be reservoir bitumen. which was defined by Rogers and others (1974) as "black, solid graphitic. or asphaltic particles or coatings within the porosity of oil- and gas-bearing reservoirs." The reservoir bitumen occurs primarily within the delta-fringe facies and is most abundant in the upper $300 \mathrm{ft}(90 \mathrm{~m})$ of the Travis Peak Formation (fig. 27). Wells with thick delta-fringe facies, such as the 


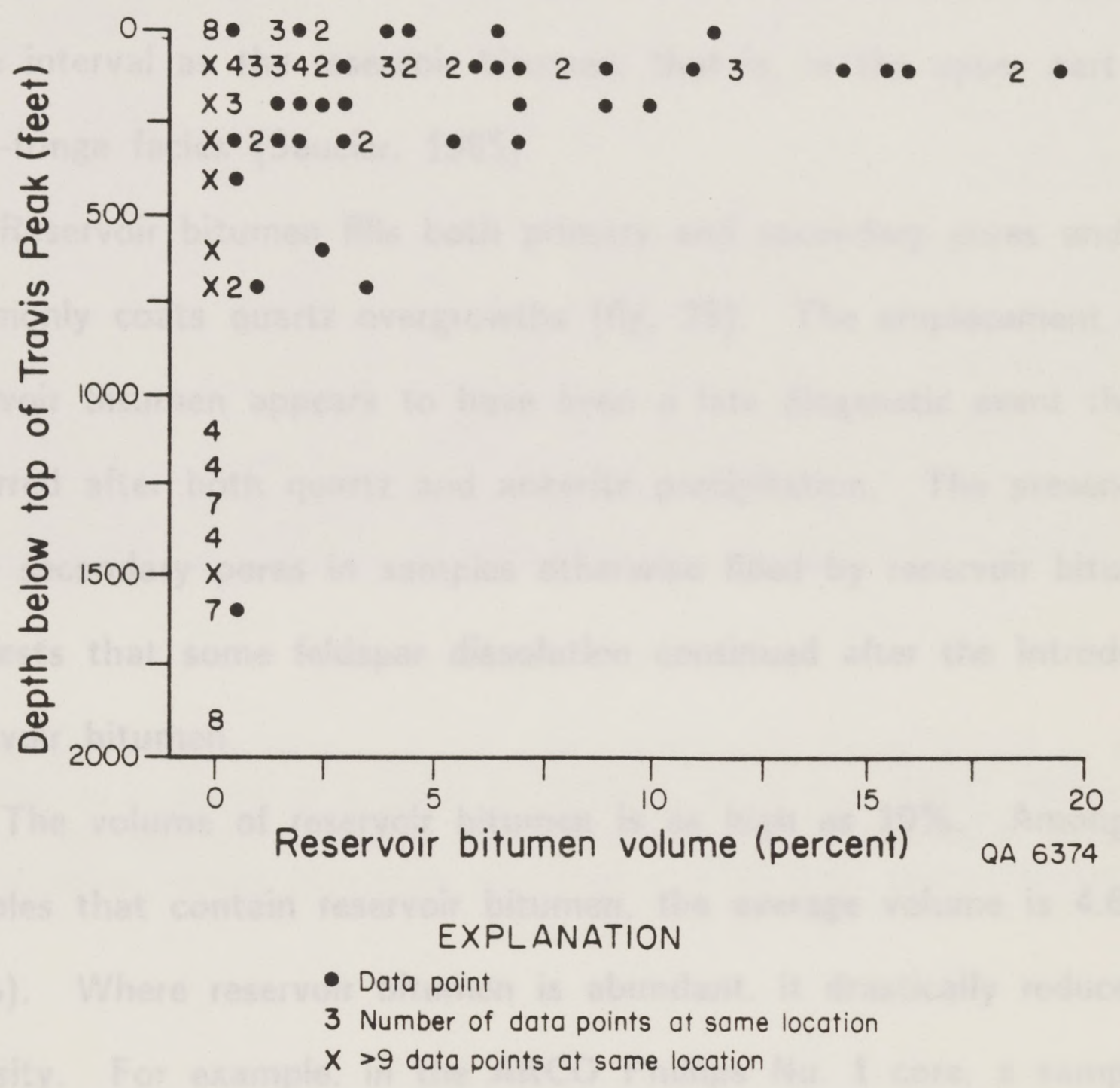

Figure 27. Reservoir bitumen volume decreases with depth below the top of the Travis Peak. 
Ashland S.F.O.T. No. 1 and Prairie Mast No. 1-A, contain only minor amounts of reservoir bitumen in the deepest part of the delta-fringe facies, 600 to $700 \mathrm{ft}(180$ to $210 \mathrm{~m})$ below the top of the Travis Peak. Most of the hydrocarbon production from the Travis Peak Formation occurs in the same interval as the reservoir bitumen, that is, in the upper part of the delta-fringe facies (Saucier, 1985).

Reservoir bitumen fills both primary and secondary pores and commonly coats quartz overgrowths (fig. 28). The emplacement of reservoir bitumen appears to have been a late diagenetic event that occurred after both quartz and ankerite precipitation. The presence of open secondary pores in samples otherwise filled by reservoir bitumen suggests that some feldspar dissolution continued after the introduction of reservoir bitumen.

The volume of reservoir bitumen is as high as $19 \%$. Among all samples that contain reservoir bitumen, the average volume is $4.6 \%(\sigma=$ $4.8 \%$ ). Where reservoir bitumen is abundant, it drastically reduces porosity. For example, in the ARCO Phillips No. 1 core, a sample from $8.246 .1 \mathrm{ft}(2.513 .4 \mathrm{~m})$ has thin-section porosity of $8.4 \%$ and no bitumen. In contrast, a sample from $8,246.8 \mathrm{ft}(2,513.6 \mathrm{~m})$ contains no thin-section porosity but $9.2 \%$ reservoir bitumen.

The reservoir bitumen apparently filled pore space that was available at the time it formed, but it did not cause dissolution of framework grains or earlier cements. Reservoir bitumen was extracted with methylene chloride from a sample from the Stallworth Renfro No. 2 well at $8.232 \mathrm{ft}$ 


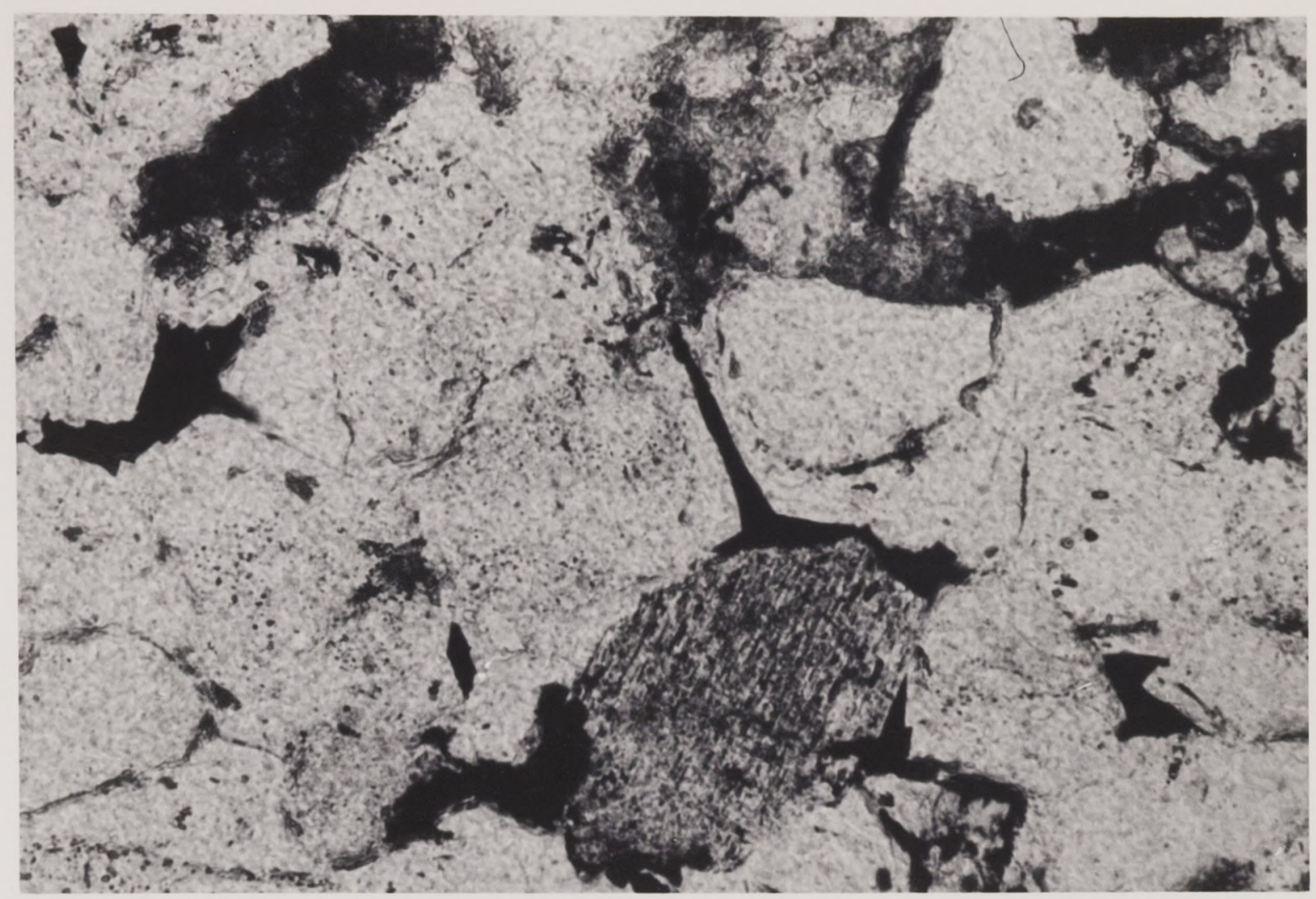

Figure 28. Photomicrograph of reservoir bitumen (dark areas) in primary porosity at a depth of $8,386.7 \mathrm{ft}(2.556 .3 \mathrm{~m})$ in the ARCO Phillips No. 1 core. The reservoir bitumen was emplaced after precipitation of quartz overgrowths. Long dimension of photo $=0.89 \mathrm{~mm}$; plane-polarized light. 
$(2.509 \mathrm{~m})$ that contains $19 \%$ reservoir bitumen, and the resulting sample was examined by SEM. No dissolution of quartz or carbonate cements was observed once the reservoir bitumen had been removed, nor had delicate authigenic clays been disturbed. Therefore, the reservoir bitumen apparently was passively emplaced in the pore space that was available at the time it entered the sandstones. Those samples that now contain abundant reservoir bitumen must have had abundant porosity remaining after all the earlier diagenetic events, because the emplacement of reservoir bitumen did not generate new porosity.

Within the delta-fringe facies, permeability differences apparently controlled the distribution of reservoir bitumen. Intervals of well-sorted rippled and crossbedded sandstones now contain the most reservoir bitumen (fig. 29), whereas burrowed and other poorly sorted sandstones contain little or no reservoir bitumen. Thus, many zones that originally had relatively high porosity and permeability are now tight because of reservoir bitumen. 


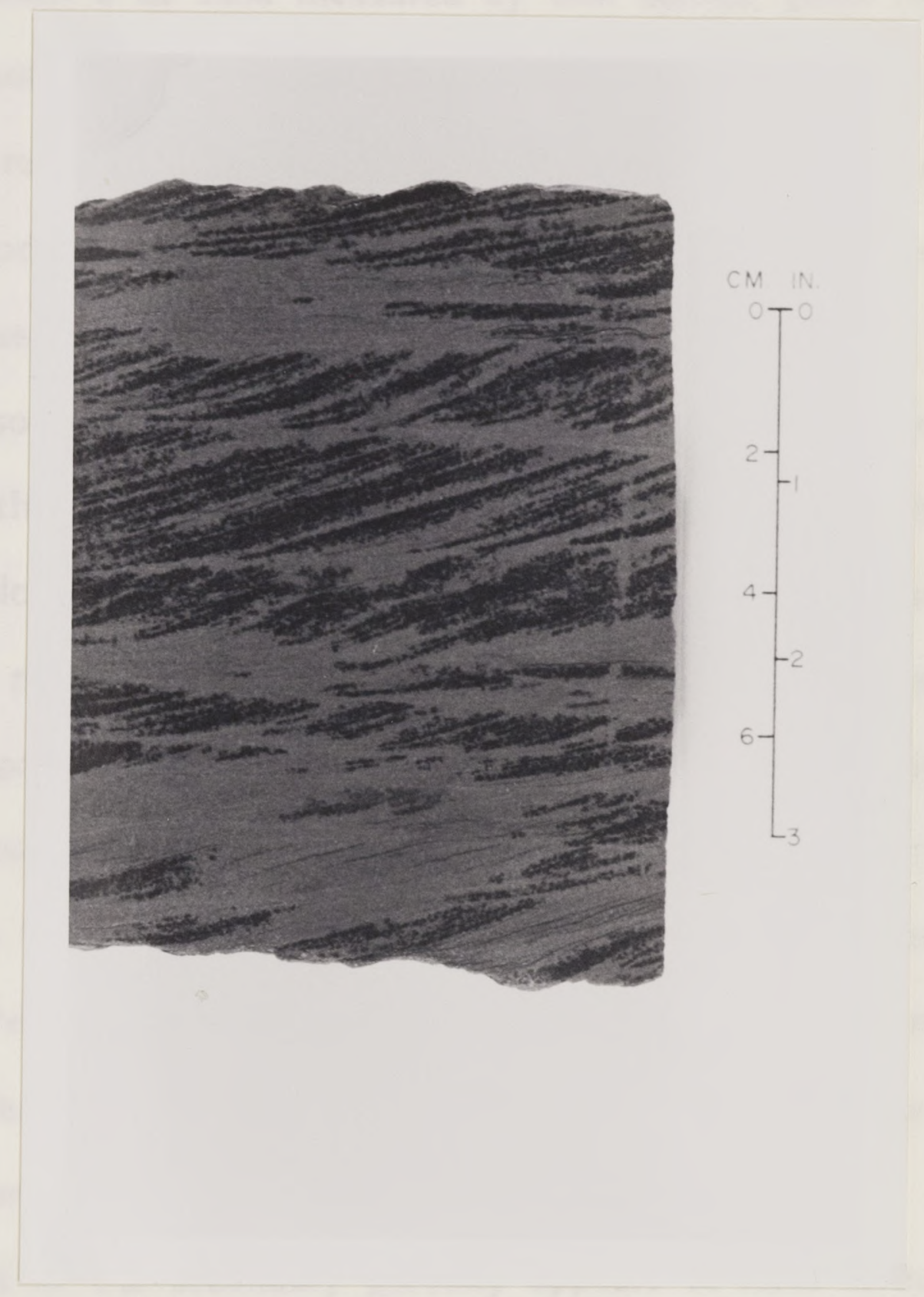

Figure 29. Rippled sandstone with reservoir bitumen highlighting ripple faces. from a depth of $8.240 .0 \mathrm{ft}(2.511 .6 \mathrm{~m})$ in the Stallworth Everett No. 2-B core. 


\section{Porosity}

The amount of porosity in Travis Peak sandstones is quite variable. ranging from 0 to $18 \%$ measured by thin section point counts. Thinsection porosity was divided into primary and secondary types: secondary porosity results from dissolution of framework grains or cements. Average primary porosity in all Travis Peak samples is $0.7 \%(\sigma=1.2 \%)$, and average secondary porosity is $2.0 \%(\sigma=2.7 \%)$. For all samples that contain some thin-section porosity, secondary porosity forms an average of $74 \%$ of the total porosity. Primary and secondary porosity decrease with depth below the top of the formation, both in mean value and in the range of porosities present (figs. 30 and 31). The retention of higher primary porosity in some sandstones at the top of the formation suggests that cementation, particularly quartz cementation, was not as uniformly extensive in this part of the section compared with deeper in the Travis Peak. Primary porosity was also retained in samples from deeper in the Travis Peak in the Arkla Scott No. 5 well because of the presence of thick illite cutans around detrital grains.

Most of the secondary porosity appears to have formed because of dissolution of detrital feldspar grains, based on the remnants found within some secondary pores. There is no evidence that dissolution of carbonate cement was responsible for generation of secondary pores in the Travis Peak. Corrosion of early dolomite cement has been observed, but the corroded dolomite has been replaced by iron-rich dolomite or ankerite. 


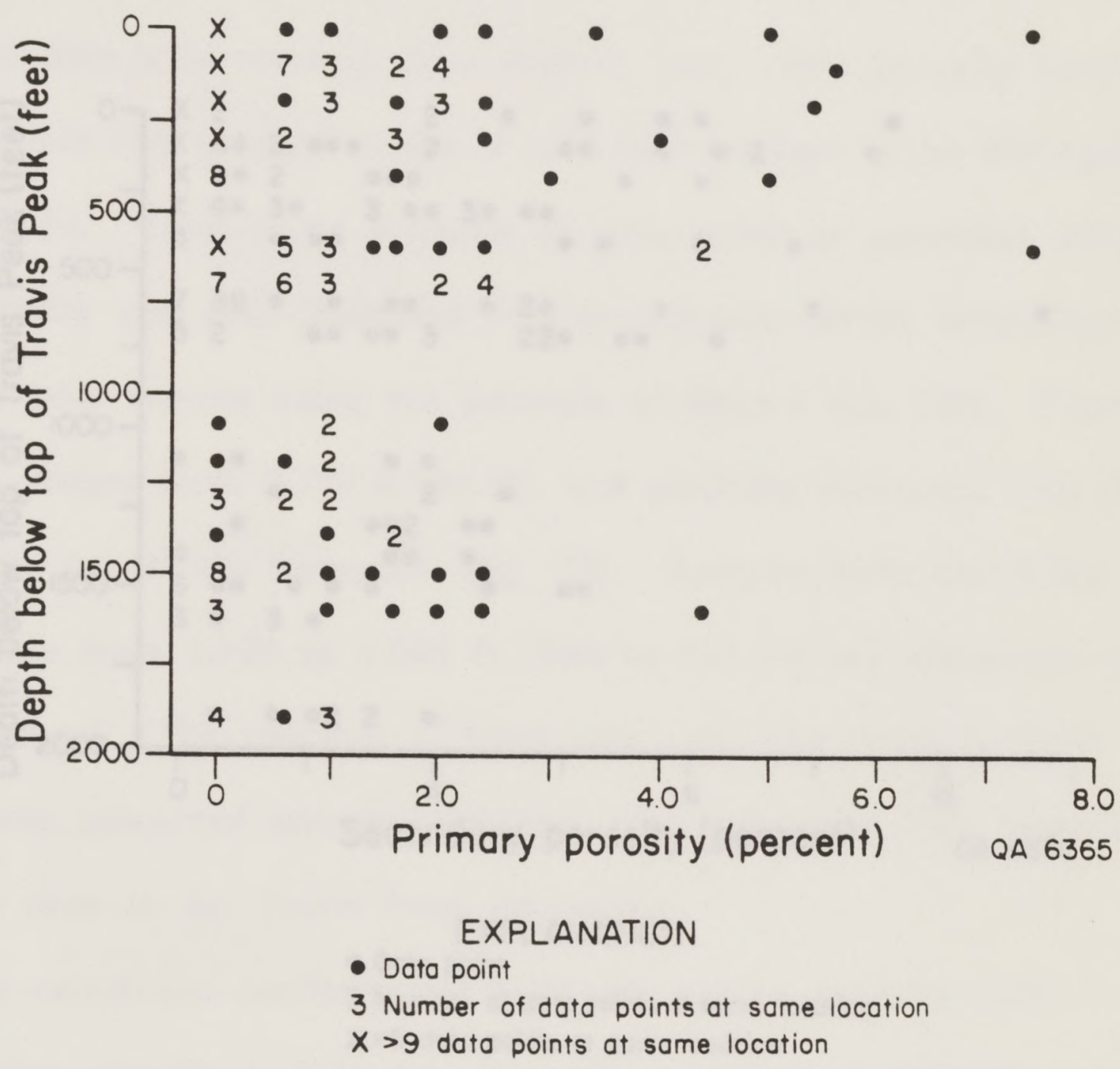

Figure 30. Primary porosity decreases with depth below the top of the Travis Peak. 


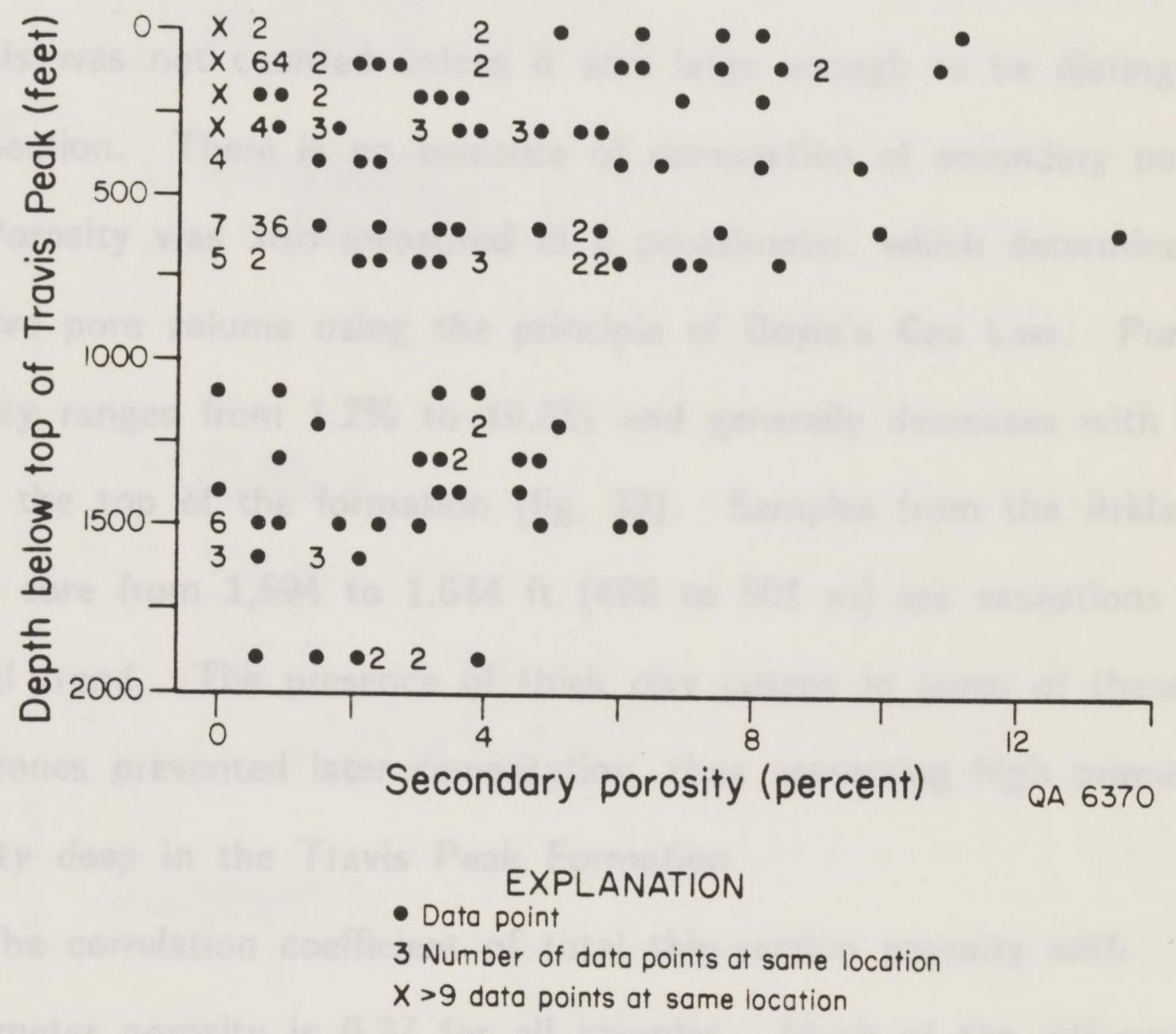

Figure 31. Secondary porosity decreases with depth below the top of the Travis Peak. 
The true average value of secondary porosity is actually somewhat higher than $2 \%$ because many secondary pores contain authigenic clay minerals with abundant microporosity between clay crystals. When these areas of clay-filled secondary pores were intersected on a point-counting traverse, they were counted as authigenic clay. Microporosity between clay crystals was not counted unless it was large enough to be distinguished in thin section. There is no evidence of compaction of secondary pores.

Porosity was also measured in a porosimeter, which determines effective pore volume using the principle of Boyle's Gas Law. Porosimeter porosity ranges from $1.2 \%$ to $19.8 \%$ and generally decreases with depth below the top of the formation (fig. 32). Samples from the Arkla Scott No. 5 core from 1.594 to $1.644 \mathrm{ft}$ (486 to $501 \mathrm{~m}$ ) are exceptions to this general trend. The presence of thick clay cutans in some of these sandstones prevented later cementation, thus preserving high primary porosity deep in the Travis Peak Formation.

The correlation coefficient of total thin-section porosity with porosimeter porosity is 0.37 for all samples. Much of the difference between values of porosity that can be observed in thin section and porosimeter-measured porosity is explained by the presence of abundant microporosity between authigenic clay crystals and within clay matrix. In matrix-free sandstones the correlation coefficient between porosimeter and thin-section porosity is 0.51 . 


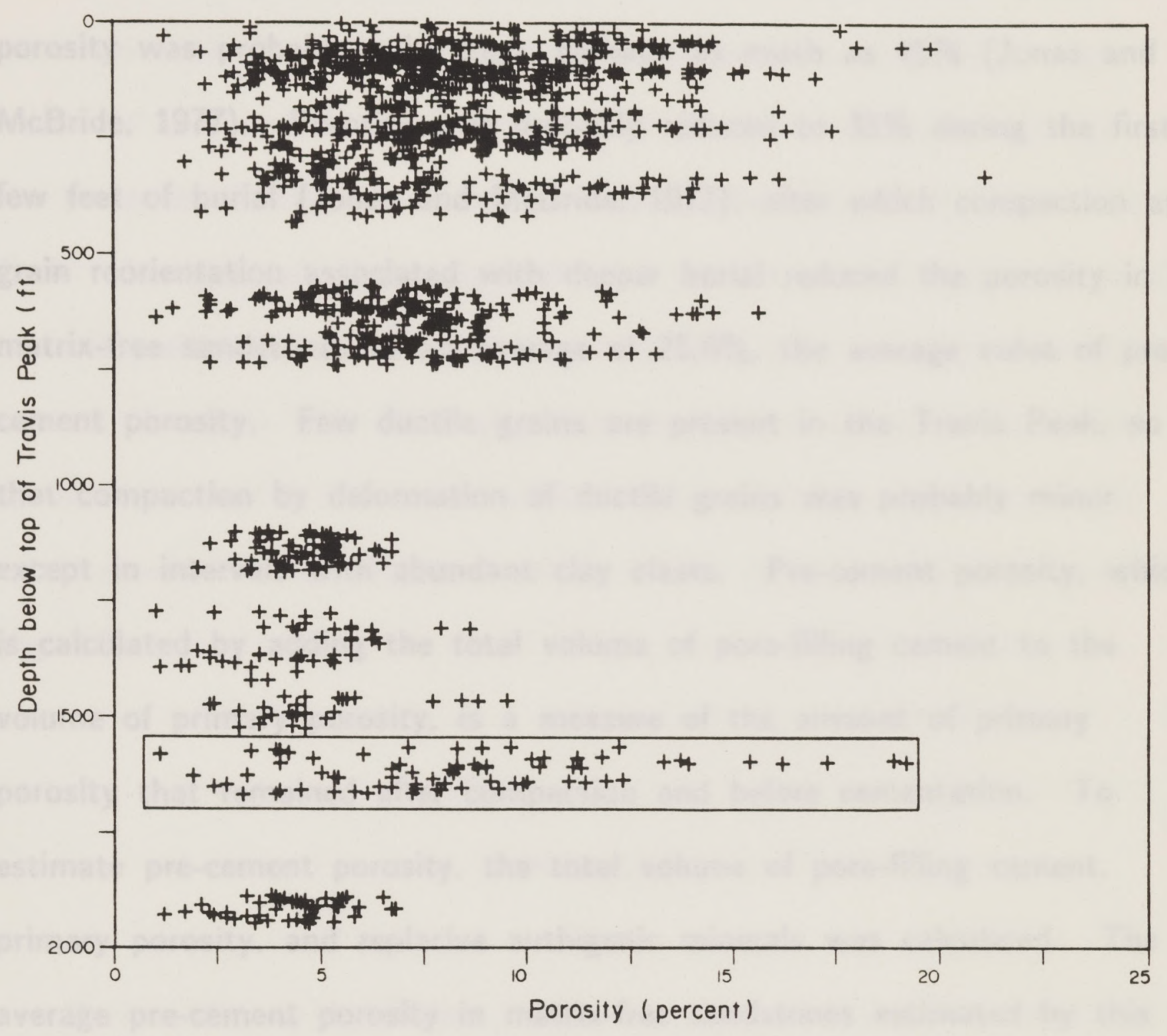

+ Data point

Somples from Arklo Scott No. 5 core

QA 6784

Figure 32. Porosimeter porosity decreases with depth in the Travis Peak. with the exception of samples from the Arkla Scott No. 5 core at 1.594 to $1.644 \mathrm{ft}(486$ to $501 \mathrm{~m})$ below the top of the formation (shown inside box). Thick illite cutans in some samples inhibited quartz cementation. such that more primary porosity was preserved in these samples. 


\section{Pre-Cement Porosity}

In the clean, well-sorted sandstones of the Travis Peak, depositional porosity was probably quite high. perhaps as much as $45 \%$ (Jonas and McBride, 1977). Porosity was probably reduced to $35 \%$ during the first few feet of burial (Jonas and McBride, 1977), after which compaction and grain reorientation associated with deeper burial reduced the porosity in matrix-free sandstones to an average of $25.6 \%$, the average value of precement porosity. Few ductile grains are present in the Travis Peak, so that compaction by deformation of ductile grains was probably minor except in intervals with abundant clay clasts. Pre-cement porosity. which is calculated by adding the total volume of pore-filling cement to the volume of primary porosity, is a measure of the amount of primary porosity that remained after compaction and before cementation. To estimate pre-cement porosity, the total volume of pore-filling cement. primary porosity, and replacive authigenic minerals was calculated. The average pre-cement porosity in matrix-free sandstones estimated by this method is $25.6 \%(\sigma=4.7 \%)$. The average volume of authigenic minerals, including reservoir bitumen, in matrix-free sandstones is $24.7 \%$ $(\sigma=5.2 \%)$. In most samples, therefore, the primary porosity that remained after compaction was almost completely occluded by authigenic minerals. Some samples of matrix-free sandstones contain as much as $40 \%$ total authigenic minerals. It is unlikely that $35 \%$ to $40 \%$ primary porosity could have remained after burial compaction; thus, to contain $35 \%$ 
to $40 \%$ authigenic minerals, these samples must have undergone dissolution and replacement of framework grains.

The range of volumes of total cement in Travis Peak sandstones decreases with depth below the top of the formation (fig. 13). High values of total cement in the upper part of the formation are caused by the presence of abundant carbonate cements in parts of the upper Travis Peak. Samples with low values of total cement in the upper part of the formation either retain abundant porosity or contain abundant detrital matrix. Samples with either abundant porosity or abundant carbonate cements are rare in the lower $1.000 \mathrm{ft}(300 \mathrm{~m})$ of the formation, thus total cement is more uniform in value in the lower part of the Travis Peak (fig. 13).

\section{Permeability}

Permeability in the Travis Peak Formation on the western flank of the Sabine Uplift is low, and much of the Travis Peak Formation is designated a tight gas sandstone. defined as having in situ permeability less than 0.1 md. Permeability of Travis Peak sandstones to air was measured in two ways. All samples were measured at surface pressure conditions (200 psi): these measurements are referred to as unstressed permeability. Selected samples were also measured under in situ conditions of overburden pressure; these measurements are referred to as stressed permeability. 
Correlation between permeability and porosimeter porosity is high, so porosimeter porosity is a good predictor of permeability. The correlation coefficient of porosimeter porosity versus log stressed permeability is 0.70 : correlation with log unstressed permeability is 0.69 .

Primary and secondary porosity determined by thin section point counts both correlate significantly with log unstressed permeability. The correlation cofficient of primary porosity versus log unstressed permeability is 0.45 ; correlation between secondary porosity and log unstressed permeability is 0.44 . (Both correlation coefficients are significant at the 99.9\% confidence level). Primary and secondary porosity have similar values of $R^{2}$, the coefficient of determination, indicating that they contribute about equally to permeability. However, secondary porosity is more abundant than primary porosity, forming $74 \%$ of the total thin-section porosity. Therefore, although considerably less primary porosity remains in Travis Peak sandstone, it is as important as secondary porosity in determining permeability.

Correlations between permeability and volume of quartz cement and volume of total cement are statistically significant. The correlation coefficient for the relationship between volume of quartz cement in matrixfree sandstones with $\log$ unstressed permeability is -0.54 if three outliers are omitted (fig. 33): although the correlation coefficient is low, this is a statistically significant linear relationship. The regression equation is as follows:

$\log$ unstressed permeability $=2.32-0.20$ [quartz cement volume $(\%)]$ 


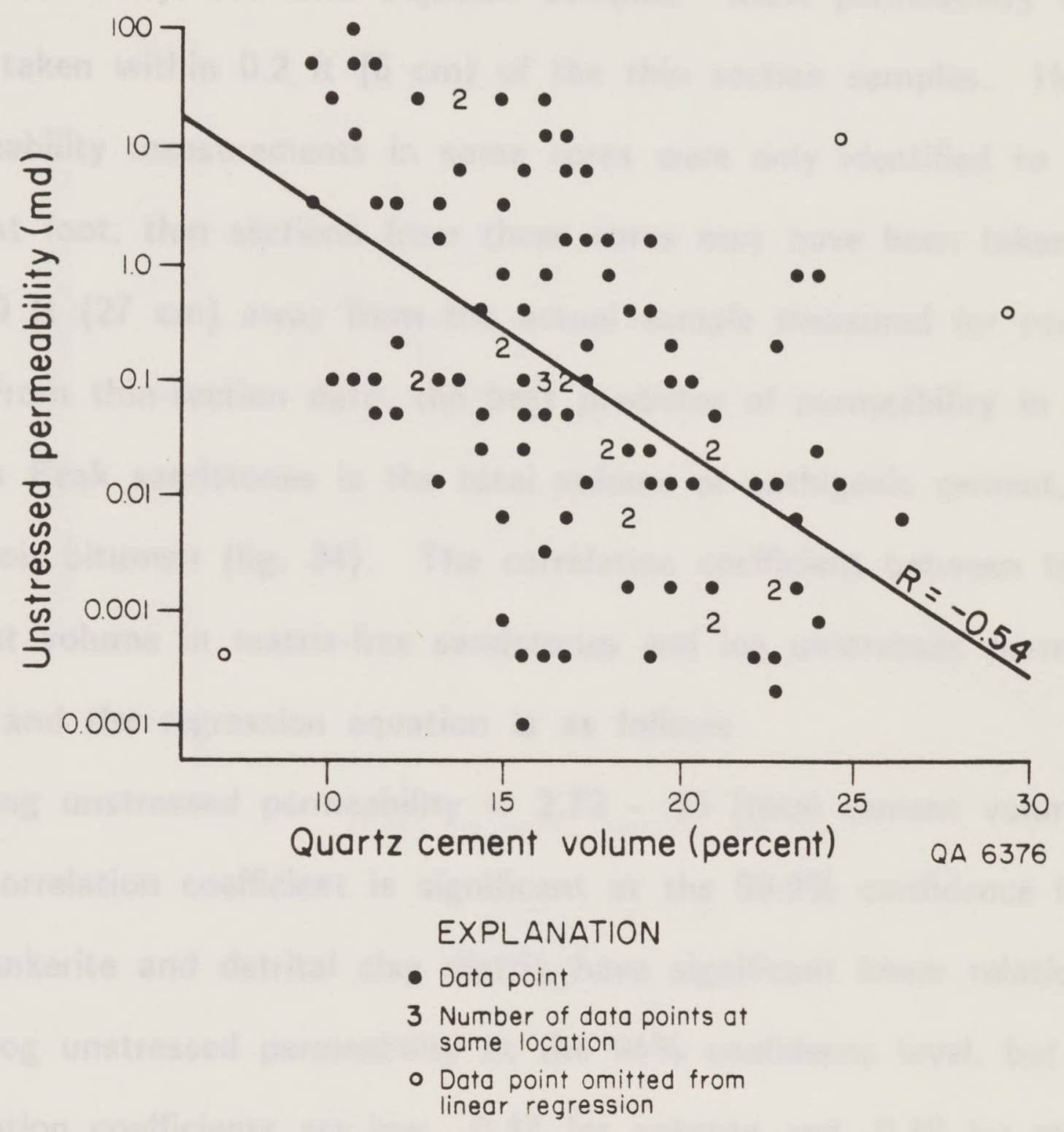

Figure 33. Inverse relationship between quartz cement volume and unstressed permeability in matrix-free sandstones. 
The correlation coefficient is significant at the $99.9 \%$ confidence level. One reason that the correlation coefficient is relatively low is that the thin sections were not made from exactly the same samples that were measured for permeability, but from adjacent samples. Most permeability samples were taken within $0.2 \mathrm{ft}(6 \mathrm{~cm})$ of the thin section samples. However. permeability measurements in some cores were only identified to the nearest foot; thin sections from these cores may have been taken as much as $0.9 \mathrm{ft}(27 \mathrm{~cm})$ away from the actual sample measured for permeability.

From thin-section data, the best predictor of permeability in well-sorted Travis Peak sandstones is the total volume of authigenic cement, including reservoir bitumen (fig. 34). The correlation coefficient between total cement volume in matrix-free sandstones and log unstressed permeability is -0.53 and the regression equation is as follows:

Log unstressed permeability $=2.72-.15$ [total cement volume $(\%)$ ] The correlation coefficient is significant at the $99.9 \%$ confidence level.

Ankerite and detrital clay matrix have significant linear relationships with $\log$ unstressed permeability at the $95 \%$ confidence level, but the correlation coefficients are low, -0.17 for ankerite and -0.19 for matrix. Parameters that do not show a significant linear relationship with permeability include grain size and volume of clay clasts, dolomite cement. authigenic clays, and reservoir bitumen.

Unstressed permeability generally decreases with depth below the top of the Travis Peak (fig. 35). A wide range of permeabilities occur near the top of the formation. but deeper in the formation the range of 


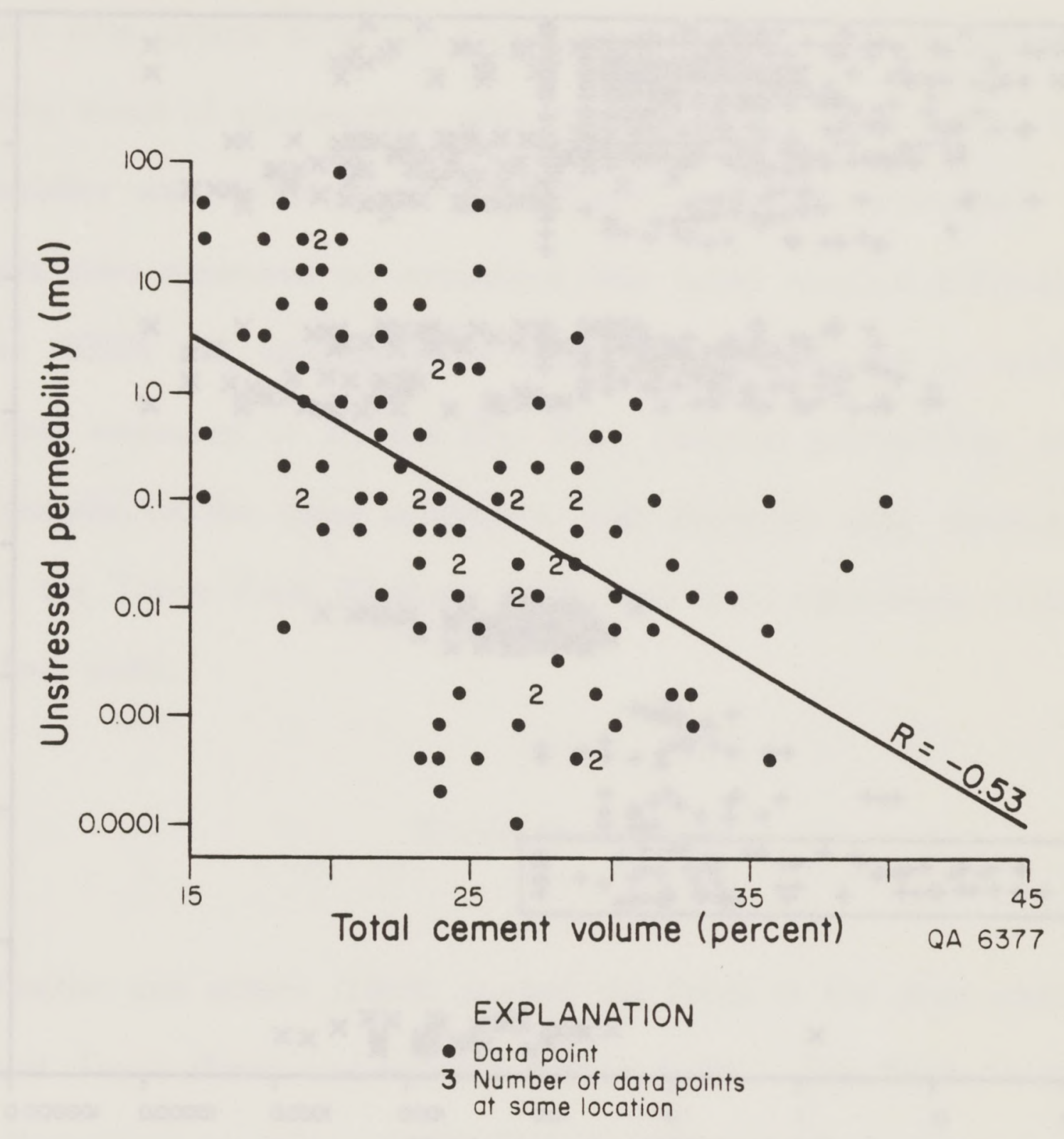

Figure 34. Inverse relationship between total cement volume and unstressed permeability in matrix-free sandstones. 


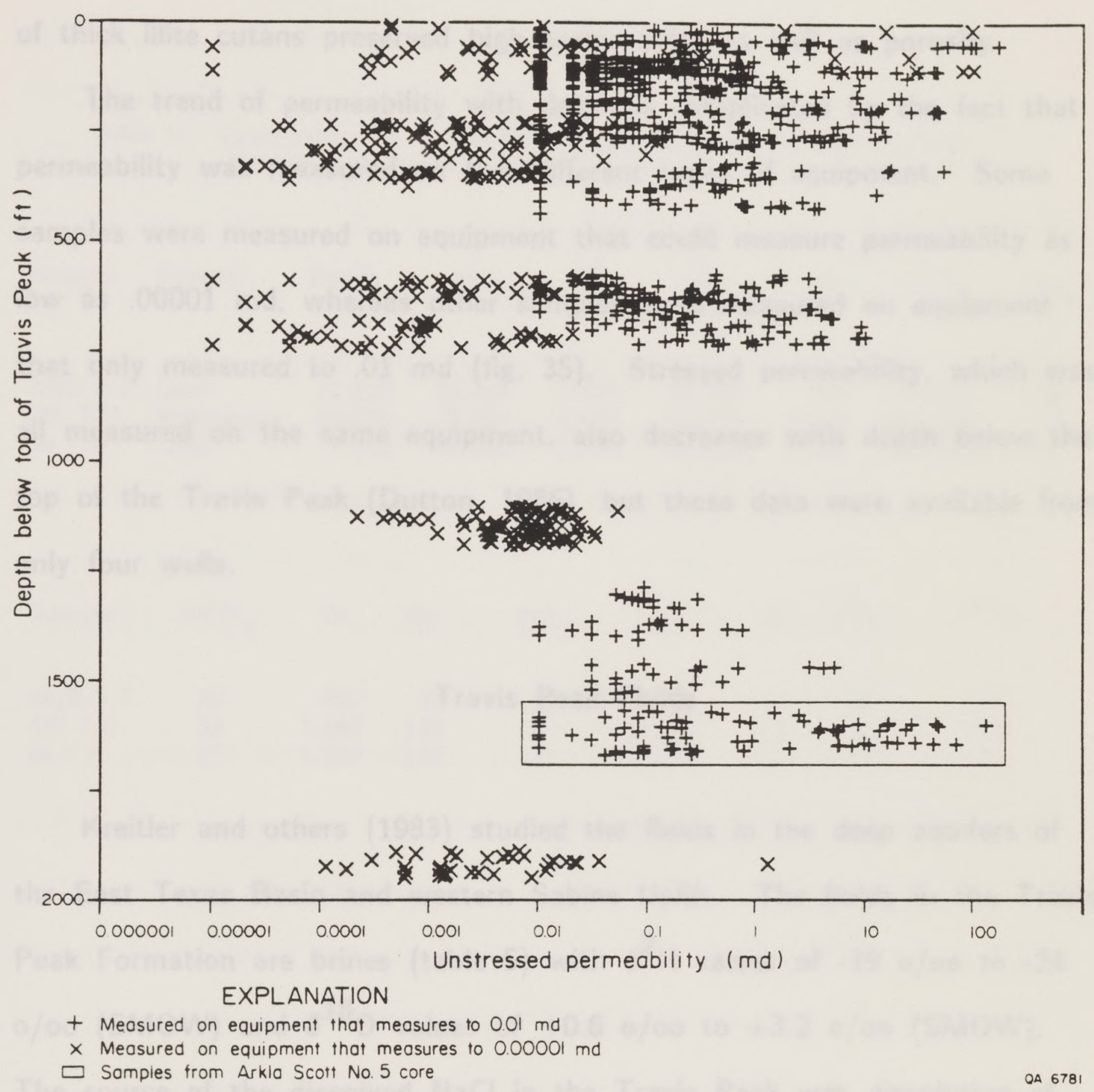

Figure 35. Permeability generally decreases below the top of the Travis Peak. with the exception of samples from the Arkla Scott No. 5 core from 1.594 to $1.644 \mathrm{ft}(486$ to $501 \mathrm{~m}$ ) below the top of the formation (shown inside box). Samples indicated by an ' $x$ ' were measured using equipment that could measure permeability to $.00001 \mathrm{md}$. whereas samples indicated by a ' + ' were measured using equipment that could measure permeability only to $.01 \mathrm{md}$. 
permeabilities and the maximum permeability decrease. Samples from the Arkla Scott No. 5 core are exceptions to the general trend. The presence of thick illite cutans preserved high permeability as well as porosity.

The trend of permeability with depth is complicated by the fact that permeability was measured on two different types of equipment. Some samples were measured on equipment that could measure permeability as low as $.00001 \mathrm{md}$, whereas other samples were measured on equipment that only measured to $.01 \mathrm{md}$ (fig. 35). Stressed permeability, which was all measured on the same equipment, also decreases with depth below the top of the Travis Peak (Dutton, 1986), but these data were available from only four wells.

\section{Travis Peak Fluids}

Kreitler and others (1983) studied the fluids in the deep aquifers of the East Texas Basin and western Sabine Uplift. The fluids in the Travis Peak Formation are brines (table 5) with $\delta^{2} \mathrm{H}$ values of $-19 \% / 00$ to -24 o/oo (SMOW) and $\delta^{18} \mathrm{O}$ values of $+0.6 \%$ oo to +3.2 o/oo (SMOW). The source of the dissolved $\mathrm{NaCl}$ in the Travis Peak was dissolution of halite from salt domes. The fluids in the deepest East Texas aquifers that were sampled, the Glen Rose and Travis Peak, have evolved from a $\mathrm{Na}-\mathrm{Cl}$ brine to a $\mathrm{Na}-\mathrm{Ca}-\mathrm{Cl}$ brine with relatively high magnesium and potassium concentrations (table 5). 
Table 5. Composition of Travis Peak water, in parts per million (from Kreitler and others. 1983).

$\begin{array}{llccrrrr}\text { Sample County } & \begin{array}{c}\text { Depth } \\ (\mathrm{ft})\end{array} & \mathrm{Na} & \mathrm{K} & \mathrm{Ca} & \mathrm{Mg} & \mathrm{Cl} & \mathrm{SO}_{4} \\ & & & & & & & \\ \text { McB.T.P. Leon } & 11.200 & 56.700 & 3.340 & 12.700 & 452 & 108.000 & 214 \\ \text { OP.T.P. Henderson } & 10.000 & 52.800 & 2.580 & 17.800 & 1.230 & 111.000 & 89 \\ \text { M.T.P. Rusk } & 7.300 & 60.600 & 1.730 & 18.000 & 1.200 & 133.000 & 217\end{array}$

$\begin{array}{lrrrrrrrr}\text { Sample } & \mathrm{HCO}_{3} & \mathrm{Br} & \mathrm{Fe} & \mathrm{SiO}_{2} & \mathrm{Sr} & \mathrm{Ba} & \delta^{2} \mathrm{H} & \delta^{18} \mathrm{O} \\ & & & & & & & & \\ \text { McB.T.P. } & 20 & 801 & 37 & 79 & 976 & 11 & -24 & +3.2 \\ \text { OP.T.P. } & 23 & 1.540 & 132 & 47 & 1.140 & 13 & -21 & +0.6 \\ \text { M.T.P. } & 27 & 1.230 & 118 & 33 & 1.180 & 13 & -19 & +2.7\end{array}$




\title{
ORGANIC GEOCHEMISTRY
}

\author{
Introduction
}

Organic matter in the Travis Peak is present as (1) dispersed detrital organic matter that occurs primarily in shales. (2) solid hydrocarbon residue that lines pores in some sandstones, and (3) gas, condensate, and liquid oil. Analysis of all three types of organic matter provides information about the diagenetic and thermal history of the Travis Peak.

\section{Detrital Organic Matter}

Analyses of detrital organic matter in Travis Peak shales were performed to determine their source rock quality and thermal maturity. The quality of a hydrocarbon source rock depends on the amount and type of organic matter. Thermal maturity is a function of both time and the temperatures to which the source rocks have been exposed (Tissot and Welte, 1978; Hunt, 1979).

Source Rock Quality

The amount of organic matter in a shale is measured as the weight 
percent of total organic carbon (TOC) in the sample. In general, shales with more than $0.5 \%$ TOC are potential hydrocarbon source rocks (Tissot and Welte, 1978). Samples from 12 Travis Peak cores were analyzed for TOC, and only two samples out of 32 contain more than $0.5 \%$ TOC (table 6). The shales in the study area are from a relatively updip stratigraphic position, and they were deposited in fluvial and nearshoremarine depositional environments where organic matter is commonly destroyed by oxidation. The low organic-matter content of shales interbedded with Travis Peak reservoir sandstones suggests that these shales were not the source of Travis Peak oil and gas.

The type of kerogen in a shale determines the kinds of hydrocarbons that can form and at what temperatures they will be generated. Kerogen type was identified microscopically in all samples that contained sufficient organic matter (table 6). Four basic types of kerogen were distinguished - amorphous, exinite, vitrinite, and inertinite. In the terminology of Tissot and Welte (1978), amorphous kerogen is called Type I, exinite is Type II, and woody kerogen is Type III. Type I kerogen is hydrogen rich, whereas Type III kerogen is oxygen rich and hydrogen deficient. Type II kerogen contains intermediate amounts of hydrogen and oxygen.

Amorphous kerogen commonly is derived from degraded algal material, but analysis of the chemical composition of amorphous kerogen indicates it may also be derived from Type II or even Type III organic matter (Tissot. 1984). Generally, it is not possible to distinguish the origin of amorphous kerogen microscopically. However, the source of amorphous kerogen is 


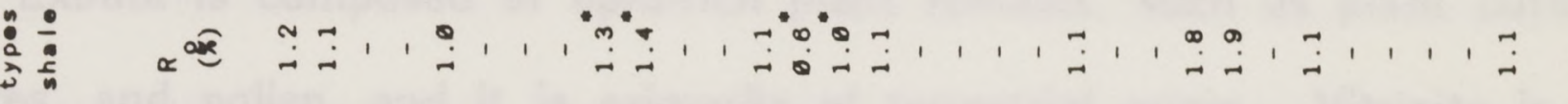

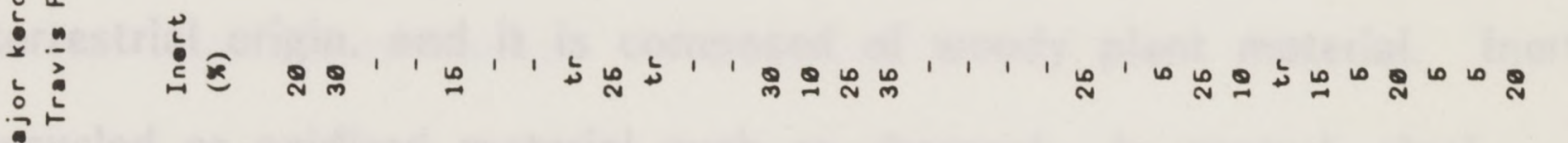
年

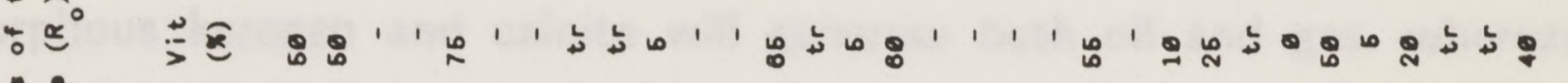

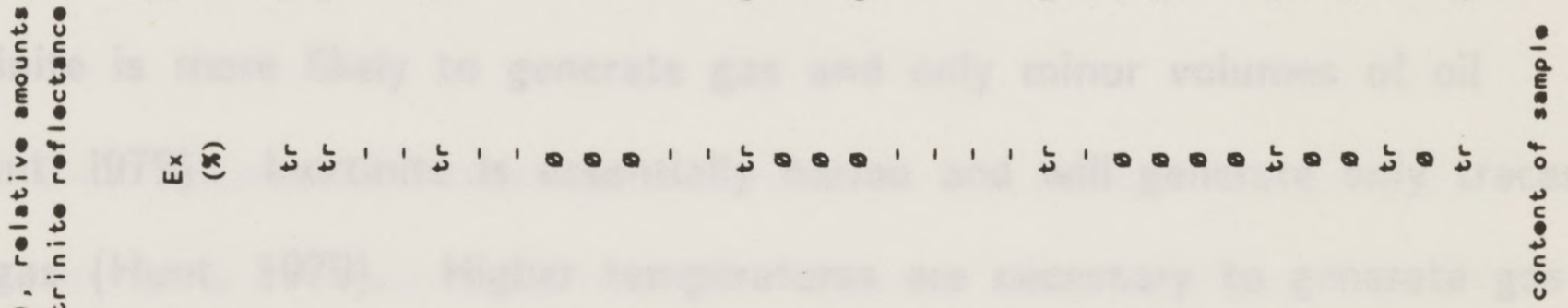

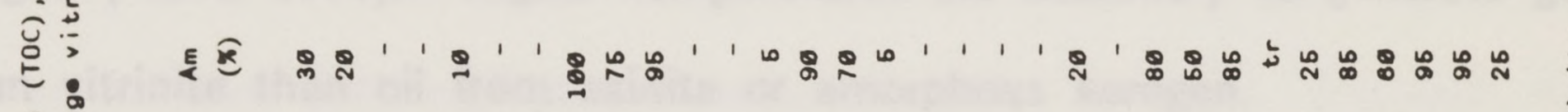
(

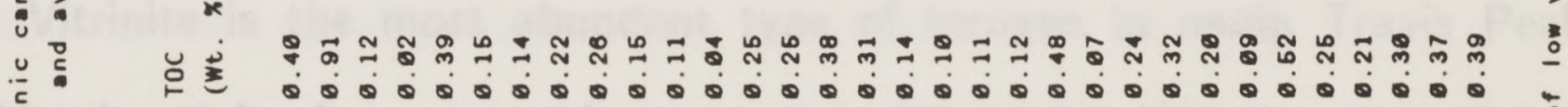

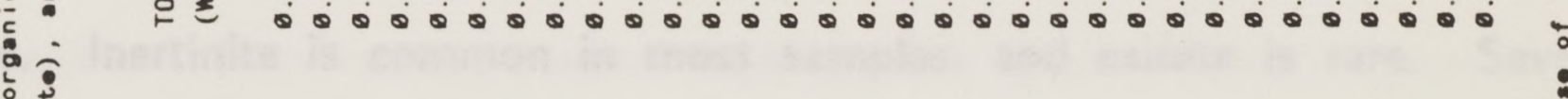

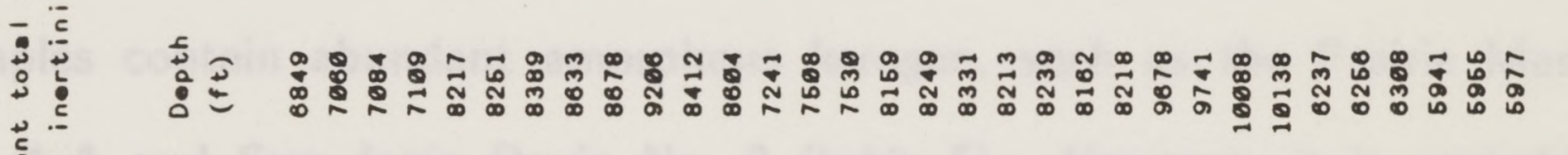

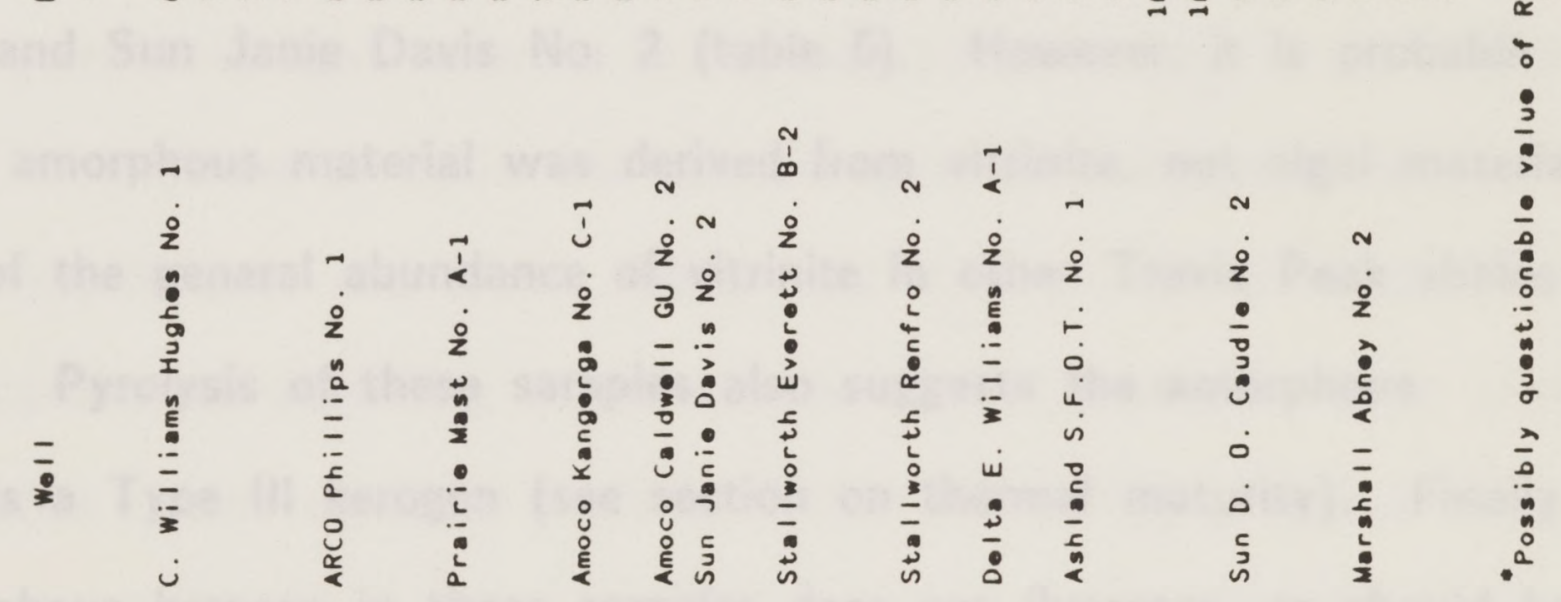


important because amorphous material derived from algae is richer in hydrogen and is therefore a better source of oil than is amorphous material derived from exinite or vitrinite.

Exinite is composed of lipid-rich plant remains, such as plant cuticle. spores, and pollen, and it is primarily of terrestrial origin. Vitrinite is also of terrestrial origin. and it is composed of woody plant material. Inertinite is recycled or oxidized material such as charcoal. In general, algal amorphous kerogen and exinite will generate both oil and gas. whereas vitrinite is more likely to generate gas and only minor volumes of oil (Hunt, 1979). Inertinite is essentially barren and will generate only traces of gas (Hunt, 1979). Higher temperatures are necessary to generate gas from vitrinite than oil from exinite or amorphous kerogen.

Vitrinite is the most abundant type of kerogen in updip Travis Peak shale. Inertinite is common in most samples, and exinite is rare. Several samples contain abundant amorphous kerogen, such as the Prairie Mast No. 1-A and Sun Janie Davis No. 2 (table 6). However, it is probable that this amorphous material was derived from vitrinite, not algal material, because of the general abundance of vitrinite in other Travis Peak shales in this area. Pyrolysis of these samples also suggests the amorphous material is a Type III kerogen (see section on thermal maturity). Finally. the amorphous kerogen in these samples does not fluoresce, as should be observed if it were hydrogen-rich, algally-derived amorphous material.

In conclusion, the source rock quality of the shales interbedded with Travis Peak reservoirs is generally poor. TOC content is less than 0.5 
percent in most samples, and Type III. woody kerogen is the most abundant type of organic matter. These shales would not be likely to generate oil, although they could generate minor amounts of gas at high enough temperatures. The oil in Travis Peak reservoir sandstones, and probably the gas as well, was probably generated in a different source rock than the interbedded shales.

Thermal Maturity

Two independent techniques were used to evaluate the level of maturity of the Travis Peak shales. Vitrinite reflectance was determined for all samples with sufficient vitrinite to obtain readings. Pyrolysis was performed on relatively organic-rich samples. Both methods can help determine if these shales reached high enough temperatures to generate gas.

The percent of light reflected by vitrinite particles $\left(R_{0}\right)$ is affected by time and temperature of burial and is, therefore, an indicator of source rock maturity (Tissot and Welte. 1978). An $R_{0}$ of $0.6 \%$ is considered to be the approximate beginning of the commercial oil generation zone; peak oil generation occurs at about $0.8 \%$ to $1.0 \%$, and at higher values of $R_{0}$ the gas/oil ratio increases (Hunt, 1979). Wet gas generation begins at an $\mathrm{R}_{\mathrm{O}}$ of about $1.0 \%$, and dry gas generation begins at about $1.2 \%$ (Dow. 1978). 
Vitrinite reflectance values measured in Travis Peak shales generally range from 1.0 to $1.2 \%$ (table 6 ). Higher $R_{0}$ values were measured in the deepest samples from the Prairie Mast No. I-A and Ashland S.F.O.T. No. 1 wells, although the $R_{0}$ readings from the Prairie Mast No. 1-A samples are of questionable value because of the low vitrinite content (table 6). The $R_{0}$ values between $1.0 \%$ and $1.2 \%$ suggest that shales interbedded with Travis Peak reservoir sandstones have reached temperatures sufficient to generate oil and wet gas and are near the beginning of the dry gas generation zone. The sample from the Ashland S.F.O.T. No. 1 has an $R_{0}$ of $1.8 \%$, which indicates it has passed through the oil-generating zone and is near the limit for preservation of wet gas (Dow, 1978). However. because of the type of kerogen in these shales, it is not likely that they have generated oil, despite having reached sufficient temperatures. They may have begun to generate minor amounts of gas. however.

A second technique for evaluating maturity of source rocks is pyrolysis (the 'Rock-Eval' method), a procedure that involves heating a shale sample in the absence of oxygen to break down large hydrocarbon molecules into smaller ones (Milner, 1982). As the temperature is gradually increased, the sample will first give off hydrocarbons (S1) that are already present in the rock either in a free or adsorbed state (Tissot and Welte, 1978). When the temperature is raised further, kerogen in the sample will generate new hydrocarbons (S2), imitating in the laboratory the natural process of hydrocarbon generation. Finally, the $\mathrm{CO}_{2}$ that is generated during pyrolysis (S3) is measured as an indication of the type of kerogen in the sample. 
whether it is humic (oxygen rich) or sapropelic (hydrogen rich) (Hunt. 1979). The temperature of maximum generation of thermally-cracked hydrocarbons $(\mathrm{S} 2)$, or $\mathrm{T}-\max \left({ }^{\circ} \mathrm{C}\right)$, is an estimate of thermal maturity. Source rocks with values of $\mathrm{T}$-max less than $435^{\circ} \mathrm{C}$ are immature (Robertson Research, personal communication, 1984). T-max values between $435^{\circ} \mathrm{C}$ and $470^{\circ} \mathrm{C}$ indicate the source rocks are in the oilgeneration zone, and values greater than $450^{\circ} \mathrm{C}$ indicate the source rock has also entered the gas-generation zone.

Travis Peak shales have $T$-max values that range from $416^{\circ} \mathrm{C}$ to $483^{\circ} \mathrm{C}$ (table 7). About half of the $\mathrm{T}$-max values are less than $435^{\circ} \mathrm{C}$. but most of the other $\mathrm{T}$-max values are greater than $450^{\circ} \mathrm{C}$. The higher T-max values are consistent with the vitrinite reflectance values. Coals and Type III kerogen with vitrinite reflectance values of $1.0 \%$ to $1.2 \%$ in general have $\mathrm{T}-\max$ values of about $440^{\circ} \mathrm{C}$ to $470^{\circ} \mathrm{C}$ (Tissot, 1984). Therefore, the group of $\mathrm{T}$-max values from $449^{\circ} \mathrm{C}$ to $483^{\circ} \mathrm{C}$ (mean $=$ $467^{\circ} \mathrm{C}$ ) probably more accurately reflects the thermal maturity of these shales. The reason for the large number of samples with low T-max values is not known. but may be due to low pyrolysis yields, which results in invalid T-max values (Dow, personal communication, 1986).

In addition to providing a measure of thermal maturity, pyrolysis also indicates the type of organic matter in the samples. The oxygen content of the kerogen is proportional to the amount of $\mathrm{CO}_{2}$ that is given off during pyrolysis, and the hydrogen content is proportional to the cracked hydrocarbons that are liberated (Hunt, 1979). The oxygen index of a 
$\stackrel{20}{3}$

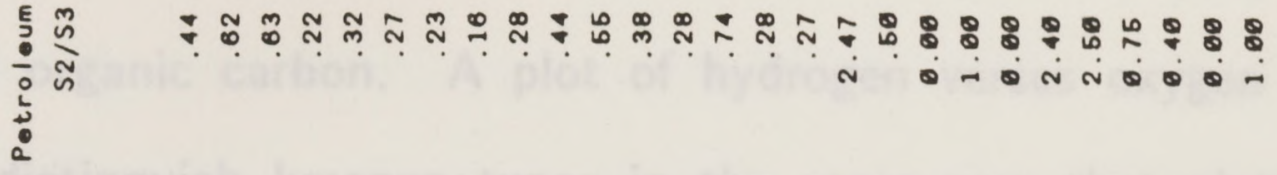

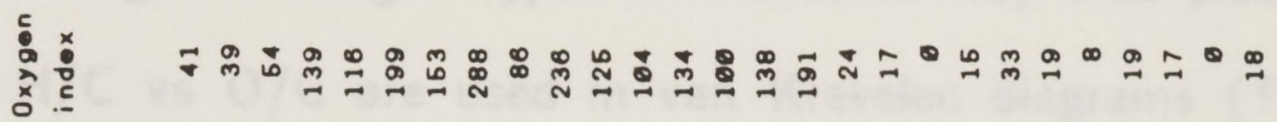

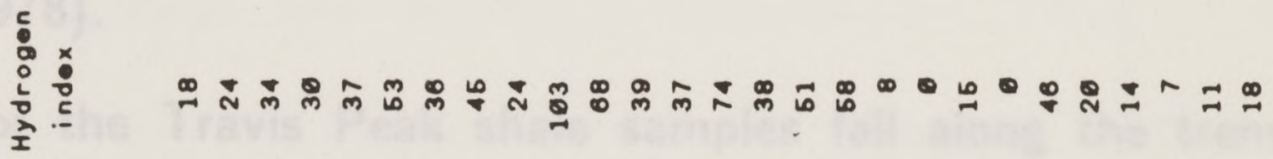

䓂

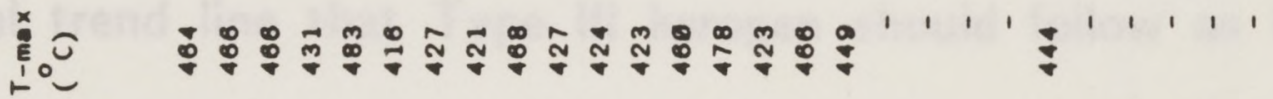

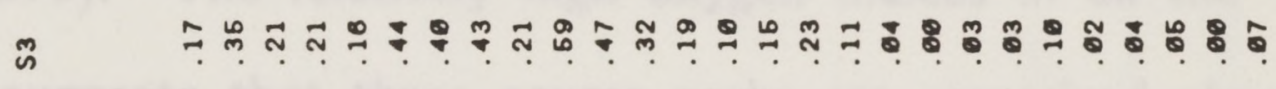

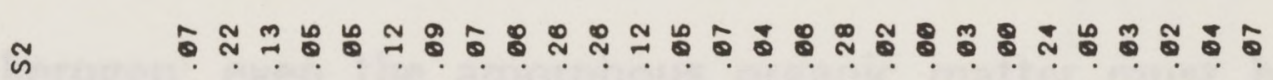

ธ

㝏

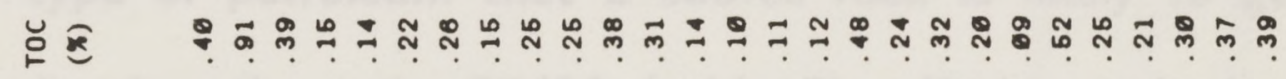

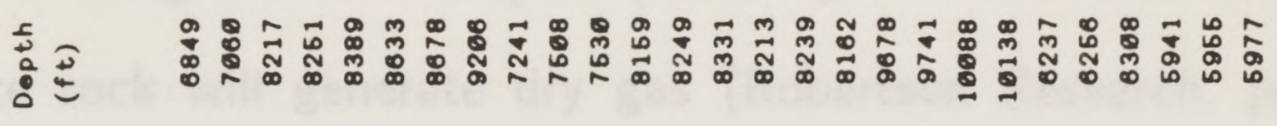

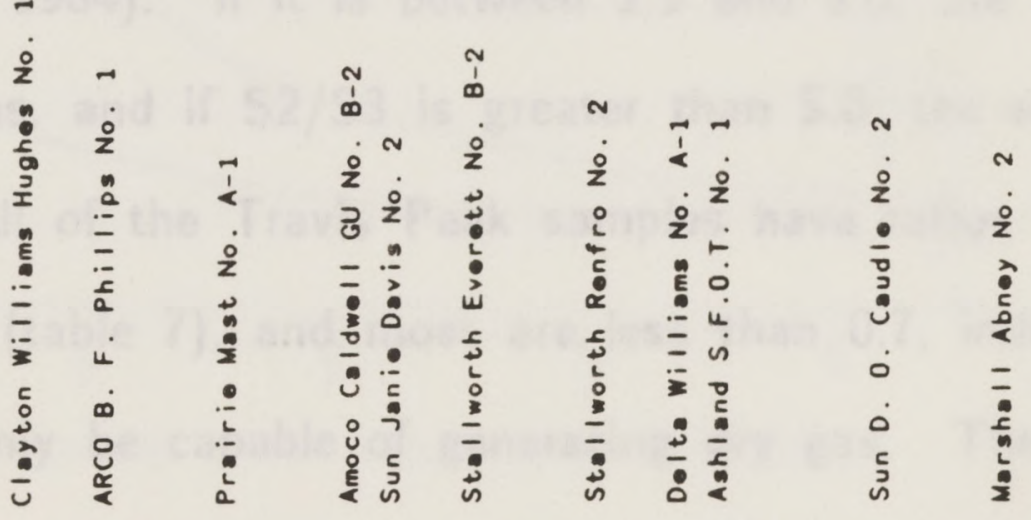


sample is defined as milligrams $\mathrm{CO}_{2}(\mathrm{~S} 3)$ divided by grams of organic carbon: similarly, the hydrogen index is milligrams HC (S2) divided by grams of organic carbon. A plot of hydrogen verses oxygen indices can be used to distinguish kerogen types in the same way that plots of atomic ratios of $\mathrm{H} / \mathrm{C}$ vs $\mathrm{O} / \mathrm{C}$ are used in van Krevelen diagrams (Tissot and Welte, 1978).

All of the Travis Peak shale samples fall along the trend of Type III kerogen (fig. 36). The more mature samples are those with low hydrogen and oxygen indices, and the less mature samples are quite close to the theoretical trend line that Type III kerogen should follow as it matures (Hunt, 1979). The relatively high oxygen indices in all the Travis Peak samples suggests that these source rocks are comprised almost entirely of Type III kerogen: even the amorphous organic matter must be derived from Type III kerogen.

The type of petroleum that a source rock is likely to generate can be determined using the ratio $\mathrm{S} 2 / \mathrm{S} 3$ (table 7 ). If this ratio is less than 2.5 , the source rock will generate dry gas (Robertson Research, personal communication, 1984). If it is between 2.5 and 5.0, the source rock will generate wet gas, and if $\mathrm{S} 2 / \mathrm{S} 3$ is greater than 5.0, the source rock will generate oil. All of the Travis Peak samples have ratios of S2/S3 that are 2.5 or less (table 7), and most are less than 0.7 , indicating that these shales should only be capable of generating dry gas. The oil and wet gas in Travis Peak reservoirs must have had a different source than these shales. 


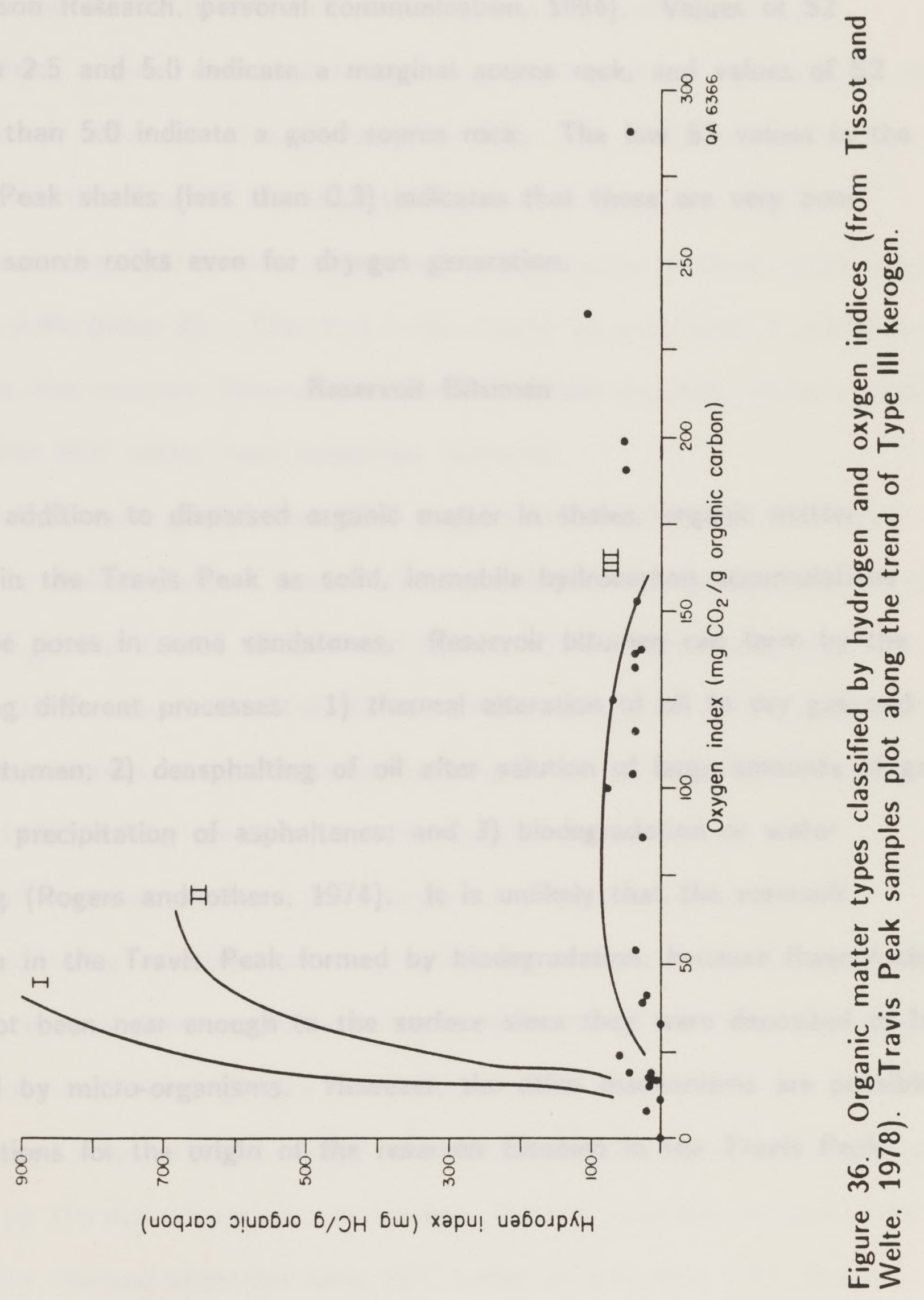


Finally, pyrolysis yields information about source-rock quality by the values of S2 (table 7). If S2 is less than 2.5, the source rock is poor (Robertson Research, personal communication, 1984). Values of S2 between 2.5 and 5.0 indicate a marginal source rock, and values of S2 greater than 5.0 indicate a good source rock. The low S2 values in the Travis Peak shales (less than 0.3 ) indicates that these are very poor quality source rocks even for dry-gas generation.

\section{Reservoir Bitumen}

In addition to dispersed organic matter in shales, organic matter occurs in the Travis Peak as solid. immobile hydrocarbon accumulations that line pores in some sandstones. Reservoir bitumen can form by the following different processes: 1) thermal alteration of oil to dry gas and solid bitumen: 2) deasphalting of oil after solution of large amounts of gas. causing precipitation of asphaltenes; and 3) biodegradation or water washing (Rogers and others, 1974). It is unlikely that the reservoir bitumen in the Travis Peak formed by biodegradation, because these rocks have not been near enough to the surface since they were deposited to be affected by micro-organisms. However, the other mechanisms are possible explanations for the origin of the reservoir bitumen in the Travis Peak. 


\section{Elemental Analysis}

In order to try to differentiate between thermal alteration and deasphalting origins, elemental analysis was performed on four samples of the reservoir bitumen. The elemental analysis was performed on kerogen concentrate that had its soluble organic material removed. The hydrogen/carbon $(\mathrm{H} / \mathrm{C})$ ratio of the remaining organic material varies from 0.79 to 0.90 (table 8 ). This $\mathrm{H} / \mathrm{C}$ ratio should be considered a minimum value for the reservoir bitumen because the soluble fraction, which probably has higher $\mathrm{H} / \mathrm{C}$ ratios, was selectively removed.

An $\mathrm{H} / \mathrm{C}$ ratio greater than 0.58 suggests that this reservoir bitumen formed by deasphalting of pooled oil after solution of large amounts of gas $\left(C_{1}\right.$ to $\left.C_{6}\right)$ into the oil (Rogers and others, 1974). When gas went into solution in the accumulated oil, it lowered the solubility of heavy molecules such as aromatics and asphaltenes, causing them to precipitate (Tissot and Welte, 1978). After precipitation, the reservoir bitumen may have continued to evolve to lower $\mathrm{H} / \mathrm{C}$ ratios by polymerization and crosslinking, resulting in more insoluble, carbon-rich material than the originally precipitated asphaltenes. Sulfur, common in reservoir bitumens, apparently promotes cross-linking (Rogers and others, 1974).

Lower values of $\mathrm{H} / \mathrm{C}$ would be expected if the reservoir bitumen had formed by thermal alteration. In western Canada, reservoir bitumens that formed by thermal alteration have $\mathrm{H} / \mathrm{C}$ ratios of less than 0.53 (Rogers and others. 1974). This type of reservoir bitumen, which is also called 
Table 8. Elemental analysis data of reservoir bitumen extracted from Travis Peak sandstones.

WeII

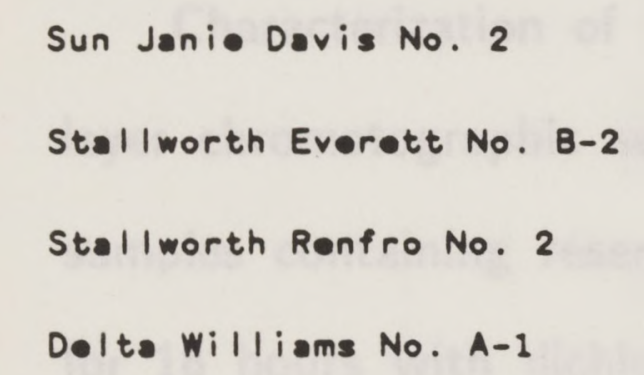

Delts Williams No. A-1
D•pt (ft)

C
7493

63.9

(x)
N

(\%)

$0+5$

(x)

Ash

(x)

sh $H / C$$$
8318
$$$$
88.4
$$

4.8

๑. 31.2

$-\quad 90$
0.90

\section{2}

88.

6.20 .0

5.4

-

๑. 85

8190

82.3

5.4

0.0

5.9

-

6. 78

6. 32.6

13.3

6.79 
pyrobitumen, is usually associated with dry gas, the other end product of thermal alteration. Pyrobitumen also differs from reservoir bitumen that formed by deasphalting because it is highly insoluble.

\section{Chromatography}

Characterization of the reservoir bitumen was also performed by thinlayer chromatographic separation of the soluble fraction. Sandstone samples containing reservoir bitumen were pulverized and soxhlet extracted for 18 hours with dichloromethane to remove the extractable fraction. The extract was then treated with hexane, which caused the asphaltenes to precipitate (a laboratory procedure that is similar to the natural process of deasphalting). The hexane-soluble fraction was separated into saturates, aromatics, and resins on a silica-alumina chromatographic column using hexane, benzene, and benzene-methanol. The relative abundance of saturates, aromatics, and resins plus asphaltenes (polars) in the extractable fraction of three reservoir bitumens is reported in table 9 .

The extractable fraction of reservoir bitumen from the Stallworth Renfro No. 2 core is very similar in composition (table 9) to normal producible crude oils reported by Tissot and Welte (1978). The reservoir bitumen extracted from the ARCO Phillips No. 1 core is enriched in saturates, somewhat depleted in aromatics, and highly depleted in polars compared to the Stallworth Renfro No. 2 sample (table 9). The abundance of polar molecules in crude oil decreases with increasing 


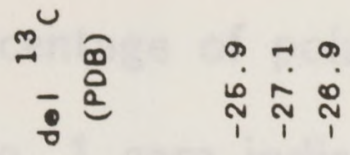

$$
\begin{aligned}
& \text { ษ } \quad \text { \& }
\end{aligned}
$$

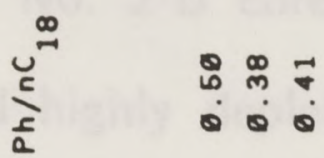

$$
\begin{aligned}
& \begin{array}{llll}
\vdots & \overrightarrow{0} & \text { ก } & \stackrel{m}{m} \\
\vdots & 0 & 0 & 0
\end{array}
\end{aligned}
$$

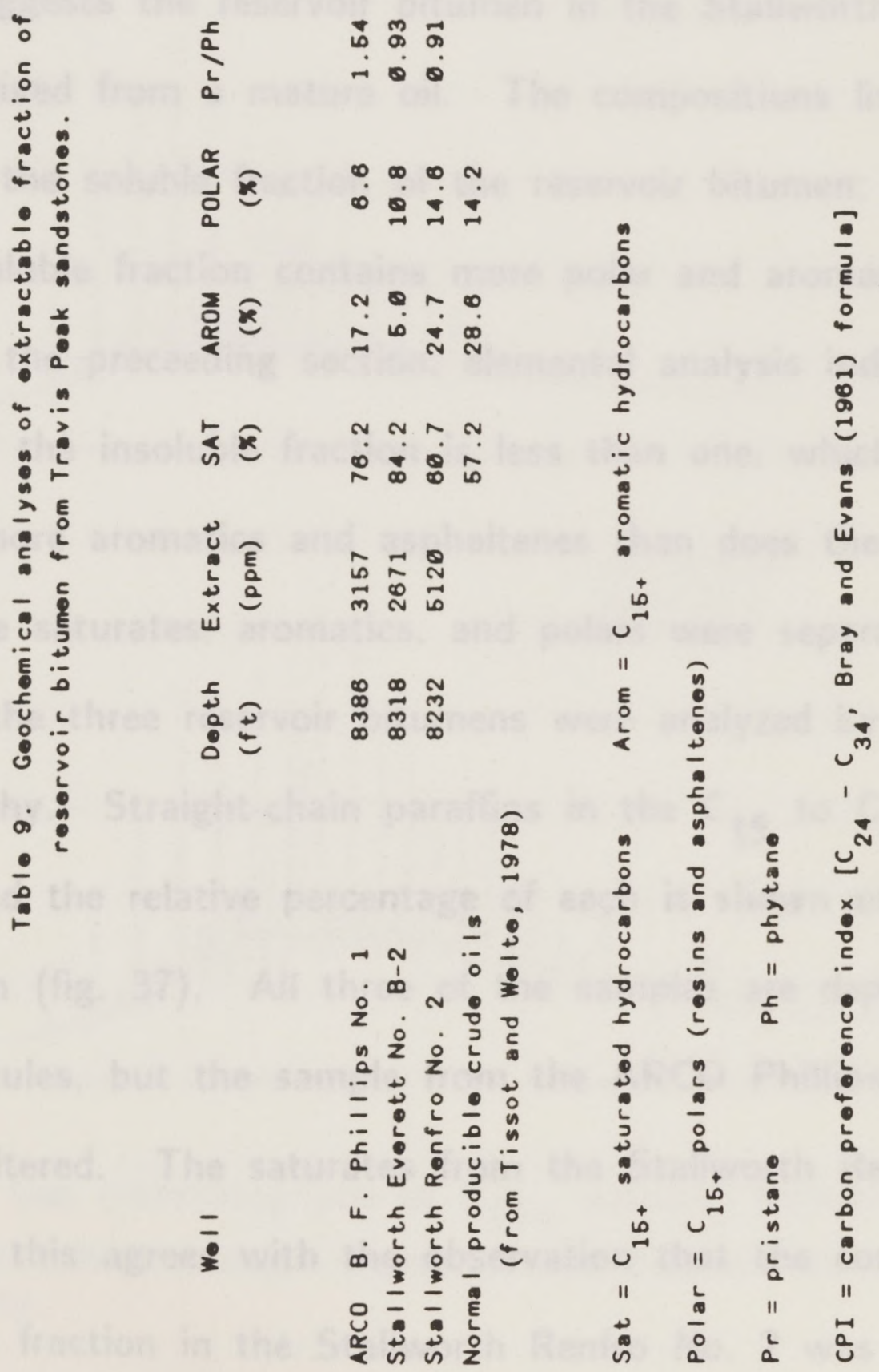


temperature and subsequent cracking (Tissot and Welte, 1978), so perhaps the relatively low percentage of polars in the reservoir-bitumen extract from the ARCO Phillips No. 1 core indicates that the oil from which it was derived was quite mature and lacked polars. In contrast, the sample from the Stallworth Everett No. 2-B core is enriched in saturates, somewhat depleted in polars, and highly depleted in aromatics compared to the Stallworth Renfro No. 2 sample. Aromatics tend to be concentrated in the heavy fractions of petroleum (Hunt, 1979). so the low percentage of aromatics suggests the reservoir bitumen in the Stallworth Everett No. 2-B was also derived from a mature oil. The compositions listed in table 9 are only for the soluble fraction of the reservoir bitumen: it is probable that the insoluble fraction contains more polar and aromatic molecules. As discussed in the preceeding section, elemental analysis indicates that the $\mathrm{H} / \mathrm{C}$ ratio of the insoluble fraction is less than one, which would suggest it contains more aromatics and asphaltenes than does the soluble fraction.

After the saturates, aromatics, and polars were separated, the saturate fractions of the three reservoir bitumens were analyzed by gas chromatography. Straight-chain paraffins in the $C_{15}$ to $C_{40}$ range were separated, and the relative percentage of each is shown on a gas chromatogram (fig. 37). All three of the samples are depleted in the heavier molecules, but the sample from the ARCO Phillips No. 1 is particularly altered. The saturates from the Stallworth Renfro No.2 are the least altered; this agrees with the observation that the composition of the entire soluble fraction in the Stallworth Renfro No. 2 was most similar to 

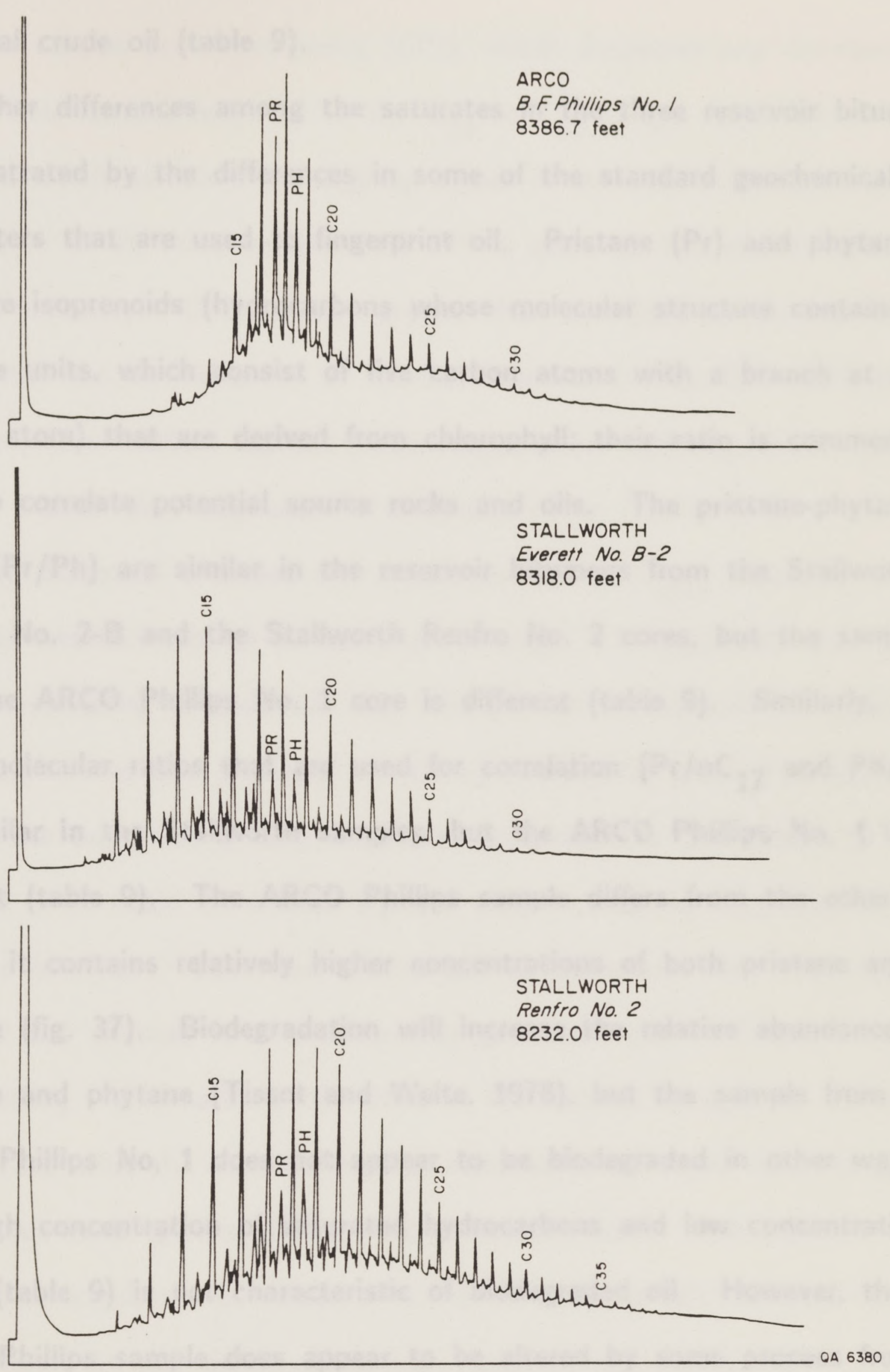

Figure 37. Gas chromatograms of $\mathrm{C}_{15+}$ saturate fraction of hydrocarbons extracted by dichloromethane from reservoir bitumen from Chapel Hill field. Smith County. 
a normal crude oil (table 9).

Other differences among the saturates in the three reservoir bitumens are illustrated by the differences in some of the standard geochemical parameters that are used to fingerprint oil. Pristane $(\operatorname{Pr})$ and phytane $(\mathrm{Ph})$ are isoprenoids (hydrocarbons whose molecular structure contains isoprene units, which consist of five carbon atoms with a branch at the second atom) that are derived from chlorophyll: their ratio is commonly used to correlate potential source rocks and oils. The pristane-phytane ratios $(\mathrm{Pr} / \mathrm{Ph})$ are similar in the reservoir bitumens from the Stallworth Everett No. 2-B and the Stallworth Renfro No. 2 cores, but the sample from the ARCO Phillips No. 1 core is different (table 9). Similarly, two other molecular ratios that are used for correlation $\left(\mathrm{Pr} / \mathrm{nC}_{17}\right.$ and $\left.\mathrm{Ph} / \mathrm{nC}_{18}\right)$ are similar in the Stallworth samples, but the ARCO Phillips No. 1 is different (table 9). The ARCO Phillips sample differs from the other two in that it contains relatively higher concentrations of both pristane and phytane (fig. 37). Biodegradation will increase the relative abundance of pristane and phytane (Tissot and Welte, 1978), but the sample from the ARCO Phillips No. 1 does not appear to be biodegraded in other ways. The high concentration of saturated hydrocarbons and low concentration of polars (table 9) is not characteristic of biodegraded oil. However, the ARCO Phillips sample does appear to be altered by some process from a normal crude, and the alteration seems to have increased the relative concentration of pristane and phytane. 
The carbon preference index (CPI), which measures any dominance of odd or even-carbon numbers in the $\mathrm{C}_{24}$ to $\mathrm{C}_{34}$ range. is similar in the two Stallworth samples and slightly higher in the ARCO Phillips sample (table 9). In all three samples the CPI is close to 1.0 , which indicates thermal maturity. CPI numbers greater than one (odd-carbon number preference) are an indication of thermal immaturity, and CPI numbers less than one (even-carbon number preference) are an indication of immature organic matter that originated in carbonate rocks (Hunt, 1979).

The elemental analyses and separation of the $\mathrm{C}_{15+}$ saturates of the reservoir bitumen provide evidence of its origin. It apparently was derived from deasphalting of crude oil that was present in the reservoir sandstones; the deasphalting was probably caused by solution of gas. The gas that caused the deasphalting may have been generated by the pooled oil as it matured or it could have been injected from outside by migration of gas into the reservoir. Continued maturation of the source rock that originally supplied the oil may have subsequently generated gas that caused the deasphalting. Alternatively, the level of maturity of kerogen in shales interbedded with the bitumen-bearing sandstones indicates that the gas could have been generated from the pooled oil itself. The adjacent shales have vitrinite reflectance values of $1.0 \%$ to $1.2 \%$, which indicates that source rocks at this depth would have been at sufficiently high temperatures to generate oil and wet gas and would have been near the dry-gas generation zone. Furthermore, pyrolysis of the reservoir bitumen itself gave $\mathrm{T}-\max$ values between $455^{\circ} \mathrm{C}$ and $463^{\circ} \mathrm{C}$, which is equivalent to 
vitrinite reflectance values of $1.1 \%$ to $1.2 \% \mathrm{R}_{\mathrm{o}}$ (Dow, personal communication, 1986). Therefore, it seems likely that oil within reservoirs that had reached the temperatures indicated by these different maturity indicators would undergo thermal alteration and generate gas. Thus, the gas that caused deasphalting of the oil to form solid bitumen could have been generated in place by thermal degredation of crude oil.

\section{Travis Peak Oil}

Three samples of oil from Travis Peak reservoirs were recovered from Chapel Hill field, from the ARCO Phillips No. 1. Stallworth Everett No. 2B. and Stallworth Renfro No. 2 wells. The oil samples were collected from bleeders on the well heads, so the oil samples come from only the sampled wells. In addition, these three wells are completed only in the Travis Peak, so only Travis Peak oil was collected.

Whole-oil gas chromatograms were run on the three oil samples (fig. 38). In general the chromatograms are quite similar, indicating that all three oils were probably derived from the same source rock (W. Dow. personal communication, 1985). However, the oils from the ARCO Phillips No. 1 and the Stallworth Renfro No. 2 wells are more mature than the oil from the Stallworth Everett No. 2-B well. The two mature oil samples have lost many of the molecules in the $C_{15}$ range, probably by normal thermal alteration and cracking. The API gravities of these three oils reflect their different levels of maturity (table 10). The relatively altered 

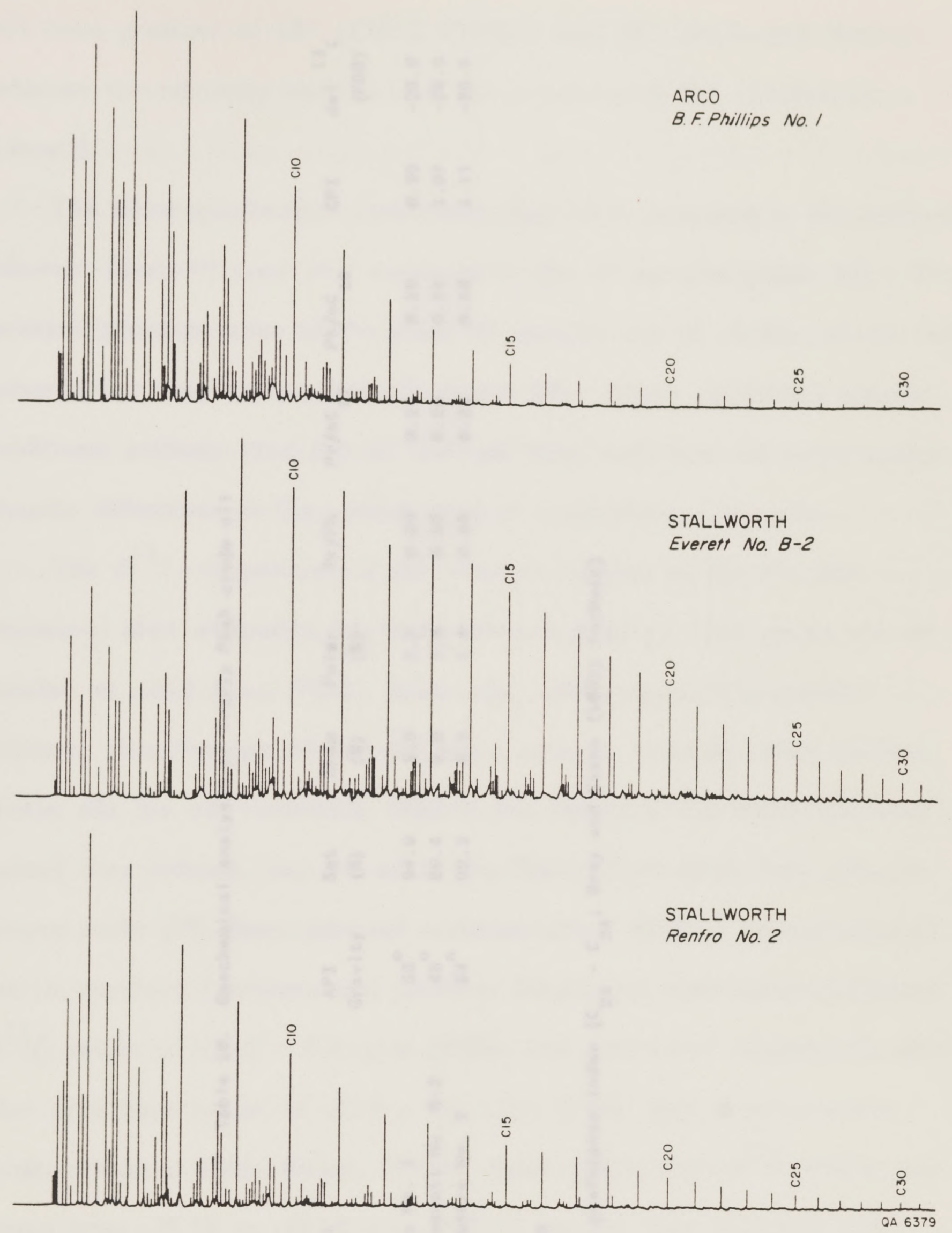

Figure 38. Gas chromatograms of Travis Peak oil from Chapel Hill field. Smith County. 


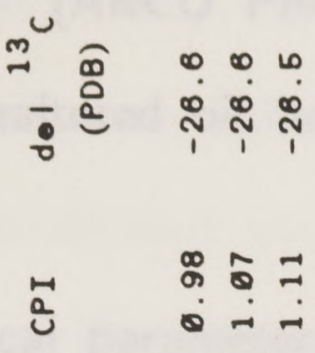

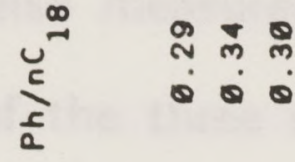

؛

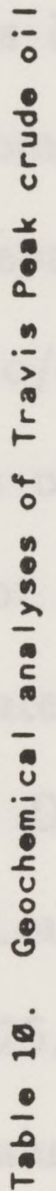

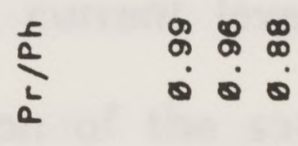

产 $\stackrel{0}{0} \stackrel{0}{-}$

$\frac{2}{\vec{J}}$

E ह

ळ

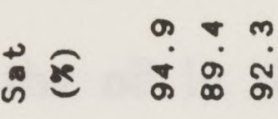

¿

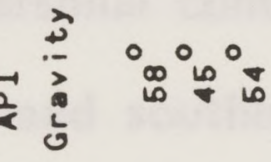

敞

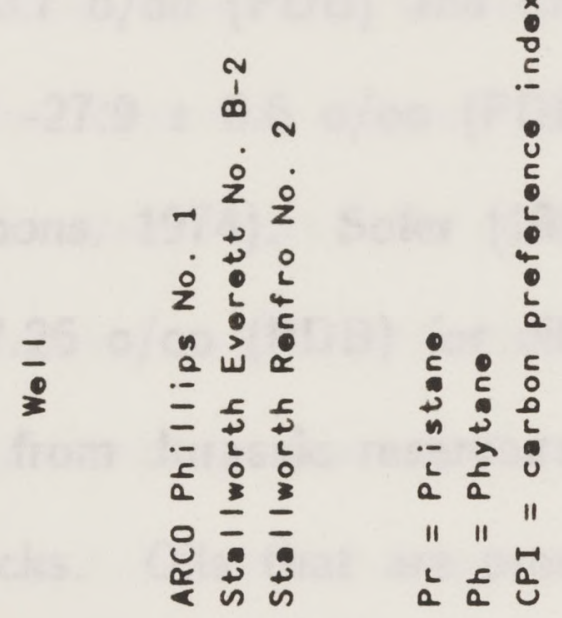


oils have gravities of $58^{\circ}$ (ARCO Phillips) and $54^{\circ}$ (Stallworth Renfro). whereas the relatively unaltered oil has a gravity of $45^{\circ}$ (Stallworth Everett).

The same geochemical parameters that were measured in the reservoir bitumen (table 9) were also measured in the oil samples (table 10). The pristane/phytane ratios of the three oil samples are all similar, as are the other ratios used to correlate oils (table 10). These similarities provide additional evidence that the oil from all three wells had the same source. despite differences in the current level of maturation of the oils.

The $\delta^{13} \mathrm{C}$ composition of the saturate fraction of the oils was measured after separation by liquid chromatography. The values are all similar, at -26.6 o/oo (PDB) (table 10). Once again, this provides evidence that the oils all had the same source. Isotopic values of East Texas oils are not commonly cited in the literature, but these measured values may indicate that the oil in the Travis Peak came from Jurassic source rocks (W. Dow. personal communication. 1985). Jurassic-sourced oils in northern Louisiana and southern Mississippi have saturate-fraction $\delta^{13} \mathrm{C}$ values of $-25.9 \pm 0.7 \circ / \mathrm{oo}(\mathrm{PDB})$ and Cretaceous sourced oils from that area have values of $-27.9 \pm 0.6 \circ / 00$ (PDB) (W. Dow, personal communication, 1985: Koons, 1974). Sofer (1984) lists $\delta^{13} \mathrm{C}$ values that range from -25.17 to -27.26 o/oo (PDB) for oils from Louisiana and Mississippi that produce from Jurassic reservoirs, and presumably were sourced from Jurassic rocks. Oils that are produced from Upper Cretaceous reservoirs in Texas have $\delta^{13} \mathrm{C}$ values that range from -28.46 to 
-29.93 o/oo (PDB) (Sofer, 1984). Prezbindowski (1985) indicates that typical Jurassic-sourced oils in south Texas have $\delta^{13} \mathrm{C}$ values of about -25 \%/oo, whereas Cretaceous-sourced oils in south Texas have $\delta^{13} \mathrm{C}$ values of about $-27.3 \circ / 00(P D B)$. Therefore, the $\delta^{13} \mathrm{C}$ values of the Travis Peak oils are in closer agreement to the published values of oils from Jurassic source rocks than oils from Cretaceous source rocks in the Gulf Coast.

The geochemical parameters that were measured in both the Travis Peak oils and reservoir bitumen (tables 9, 10) provide evidence that the reservoir bitumen was derived from oils that were very similar to the oils presently in the Travis Peak. In general, the pristane/phytane, $\mathrm{Pr} / \mathrm{nC}_{17}$. $\mathrm{Ph} / \mathrm{nC}_{18}$, and $\mathrm{CPI}$ values are similar between the oil and reservoir bitumen for each well (tables 9, 10). The largest differences are in the ARCO Phillips No. 1 well between the oil and reservoir bitumen. Oil from the ARCO Phillips well is rather different and more mature than oils from the two Stallworth wells, but reservoir bitumen in the ARCO Phillips well is very similar to bitumen in the Stallworth wells. In all three wells, the ratios of pristane and phytane to their adjacent normal alkanes (table 10) suggests that the oil is more mature (contains more normal alkanes) than the reservoir bitumen from that well. Either the reservoir bitumen precipitated out of the oil when it was not as mature as it is today, or pristane and phytane were preferentially precipitated into the bitumen when gas entered the pooled oil. leaving more of the normal alkanes in the oil. However, the most important conclusion that can be drawn from the geochemical parameters is that the reservoir bitumen appears to have been 
precipitated from an oil very similar to that which is in the Travis Peak today.

\section{Source of Travis Peak Oil}

The organic geochemical studies necessary to type an oil and relate it to a particular source rock were beyond the scope of this study. However. the organic geochemical work that was done, in combination with stratigraphic and structural information about the Sabine Uplift area, can provide circumstantial evidence with which to try to identify the source rocks that generated the Travis Peak oil. The four main possibilities are (1) carbonate mudstones of the lower Smackover Formation (Sassen and others, 1986a); (2) dark basinal shales of the Bossier Formation (Collins. 1980): (3) downdip marine shales of the Travis Peak Formation: and (4) shales of the Upper Cretaceous Eagle Ford Group.

The Eagle Ford shales are probably the source rocks for oil in the Woodbine Group in East Texas (Prezbindowski, personal communication, 1986), but it does not seem likely they could have been the source rocks for the oil in the Travis Peak. The Eagle Ford occurs about $4.000 \mathrm{ft}$ $(1.200 \mathrm{~m})$ higher in the stratigraphic section (fig. 4) than the top of the Travis Peak (Wood and Guevara, 1981: Halbouty and Halbouty, 1982), and in the present configuration of the East Texas Basin, it does not seem possible that oil generated in the Eagle Ford could have migrated down section into the Travis Peak. Furthermore, published carbon isotopic 
values of oils generated in Upper Cretaceous source rocks (Sofer, 1984) indicate that oils from this source are lighter than Travis Peak oil.

Laminated carbonate mudstones of the lower Smackover (fig. 4) have been identified as the source rocks for oil in Smackover reservoirs (Sassen and others, 1986a). However, the evaporites of the overlying Buckner Formation (fig. 4) probably acted as seals that prevented much of the oil generated in the lower Smackover from migrating past the upper Smackover (Sassen and others, 1986b).

Little is known about marine shales of the Travis Peak Formation that were deposited downdip from the fluvial and marginal-marine sandstones in the study area (fig. 5). Because of their environment of deposition. however, they are likely to be better source rocks than the updip Travis Peak shales that are interbedded with Travis Peak reservoirs. These marine shales are located mainly in Louisiana, and fairly long lateral migration would be necessary to carry oil generated in them to the sandstones in the study area. However, at the present time there is not enough information to determine if the downdip, marine Travis Peak shales were the source rocks for Travis Peak oil.

The Bossier Formation (fig. 4), which consists of dark basinal shales (Collins, 1980), is the offshore marine equivalent of the Cotton Valley clastics (Stewart, 1984). The Bossier Formation would seem to be a likely source for oil and gas in the Cotton Valley and Travis Peak Formations. It is about $900 \mathrm{ft}(275 \mathrm{~m})$ thick in Panola County, and it is separated from the base of the Travis Peak by 800 to $1700 \mathrm{ft}(245$ to $520 \mathrm{~m})$ of 
Cotton Valley sandstones. Vertical migration along faults and fractures would have been necessary to carry oil generated in the Bossier into the Travis Peak Formation. Reservoir bitumen was observed in fractures in the Ashland S.F.O.T. No. 1 core, and many of the Travis Peak fields such as Chapel Hill are located in fault-bounded anticlines. This evidence supports the interpretation that the oil in the Travis Peak was generated in a deeper stratigraphic unit and migrated vertically into the Travis Peak. Finally, as discussed in the previous section, published isotopic values of Jurassic-sourced oil are similar to those measured in Travis Peak oil. Therefore, the Bossier shales appear to be the most probable source rocks of Travis Peak oil based on available data. 


\section{BURIAL AND THERMAL HISTORY}

In order to more completely interpret the diagenetic history of the Travis Peak, it is necessary to estimate the burial depth and temperature of the formation through time. Stratigraphic information was used to reconstruct the burial history, and models for crustal extension and resulting heat-flow elevation were combined with data on the modern geothermal gradient to estimate the paleogeothermal gradient since deposition. With this information, it is possible to construct burial-history curves that provide an estimate of the time at which the formation reached any given temperature of interest.

\section{Burial-History Curves}

Burial-history curves of the top of the Travis Peak and Cotton Valley Formations were plotted for seven wells (table 11) on top of the Sabine Uplift and on its western and southwestern flank; two representative curves are shown in figure 39. In addition, the burial-history curve for the top of the Bossier shale, the inferred source of Travis Peak hydrocarbons, was also plotted. The burial-history curves plot total overburden thickness versus time, using present, compacted thicknesses of the stratigraphic units (fig. 39). Sediment compaction through time was not incorporated into the curves because there are no thick shale sections in this area. 
(a)

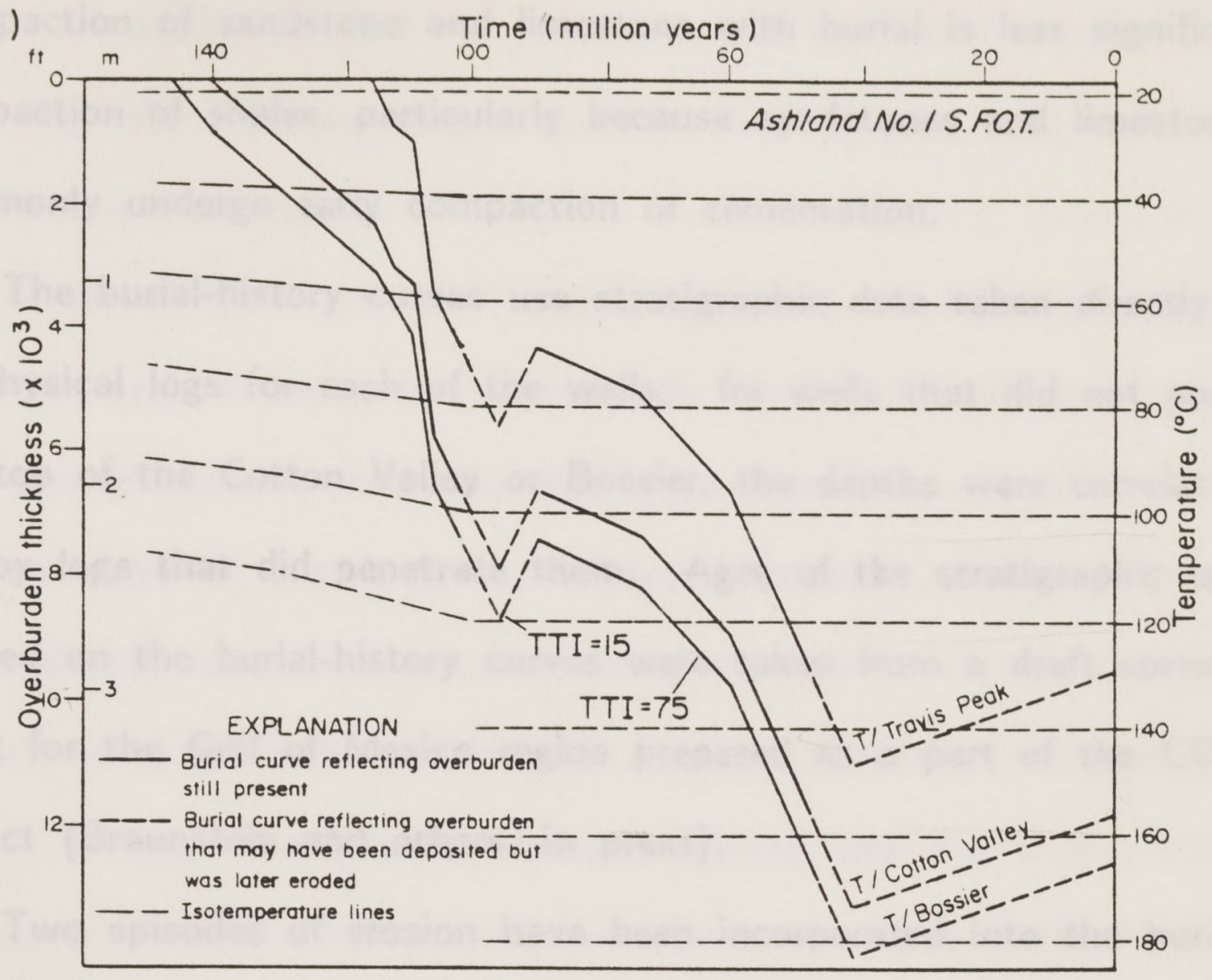

(b)

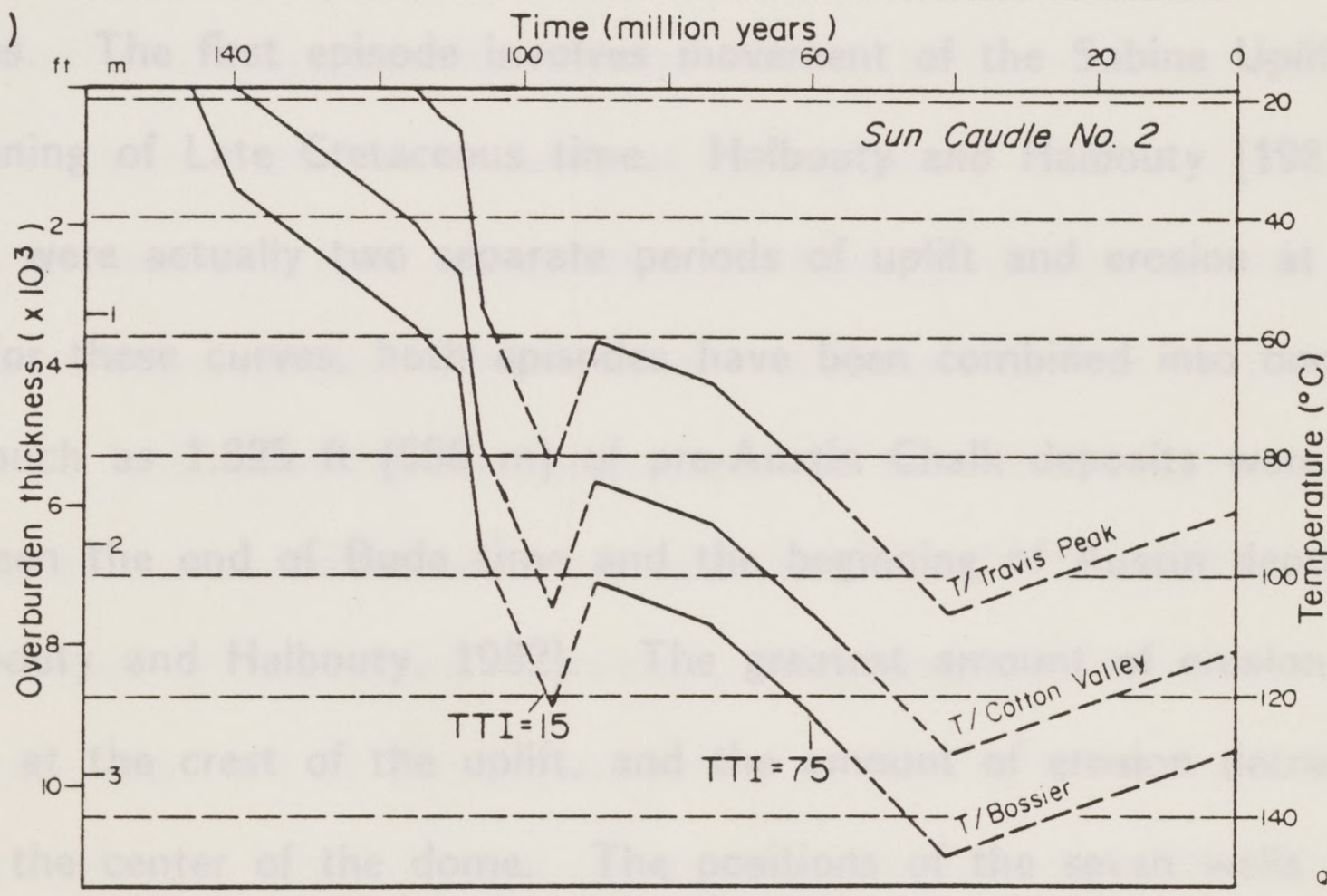

Figure 39. Burial-history curves for the tops of the Travis Peak. Cotton Valley, and Bossier Formations in the A) Ashland S.F.O.T. No. 1 and B) Sun Caudle No. 2 wells. Time-temperature index (TTI) values were calculated according to the method of Waples (1980). The times at which the Bossier shale reached TTI values of 15 and 75 are shown. 
Compaction of sandstone and limestone with burial is less significant than compaction of shales, particularly because sandstones and limestones commonly undergo early compaction or cementation.

The burial-history curves use stratigraphic data taken directly from geophysical logs for each of the wells; for wells that did not penetrate the top of the Cotton Valley or Bossier, the depths were correlated from nearby logs that did penetrate them. Ages of the stratigraphic units plotted on the burial-history curves were taken from a draft correlation chart for the Gulf of Mexico region prepared as a part of the COSUNA project (Braunstein and others, in press).

Two episodes of erosion have been incorporated into the burial-history curves. The first episode involves movement of the Sabine Uplift at the beginning of Late Cretaceous time. Halbouty and Halbouty (1982) believe there were actually two separate periods of uplift and erosion at this time. but for these curves, both episodes have been combined into one (fig. 39). As much as $1.825 \mathrm{ft}(556 \mathrm{~m})$ of pre-Austin Chalk deposits were removed between the end of Buda time and the beginning of Austin deposition (Halbouty and Halbouty, 1982). The greatest amount of erosion took place at the crest of the uplift, and the amount of erosion decreased away from the center of the dome. The positions of the seven wells for which burial-history curves were constructed were projected onto an east-west cross section of Halbouty and Halbouty (1982) that shows the amount of erosion that took place on the crest and western flank of the Sabine Uplift. The inferred amount of sediments that were once deposited and 
were subsequently eroded are shown on the burial-history curves as dashed lines (fig. 39). Erosion ended approximately 90 mya with the beginning of Austin Chalk deposition.

A second period of uplift and erosion is inferred to have taken place since the end of the middle Eocene, 41 mya. The total amount of Wilcox and younger Eocene sediments that may have been deposited in the area and subsequently eroded is not known. However, vitrinite reflectance data from Wilcox sub-bituminous coals that are now at or near land surface provide some evidence about burial history. Coals from Martin Lake mine. Panola County. Darco mine. Harrison County, and Big Brown mine. Freestone County, all have vitrinite reflectance values of $0.37 \%$ to $0.40 \%$ (P. Mukhopadhyay, personal communication, 1986). These coals have probably been buried to a depth of approximately $1.500 \mathrm{ft}(450 \mathrm{~m})$ to have attained this level of maturity ( $P$. Mukhopadhyay, personal communication, 1986). Therefore, an additional $1.500 \mathrm{ft}(450 \mathrm{~m})$ of sediment is inferred to have been deposited over the study area. The timing of the deposition and subsequent erosion of this $1.500 \mathrm{ft}(450 \mathrm{~m})$ of sediment is not known. However, the youngest sediments that remain in East Texas are in the Yegua Formation (fig. 4) (Wood and Guevara, 1981). On the burial history curves, therefore, all deposition is shown as taking place by the end of Yegua time. Erosion is arbitrarily shown as taking place continuously since the end of Yegua time, 41 million years ago, to the present (fig. 39). 


\section{Thermal History}

The present geothermal gradient in the study area is approximately $2.1^{\circ} \mathrm{F} / 100 \mathrm{ft}\left(38.3^{\circ} \mathrm{C} / \mathrm{km}\right)$. Geothermal gradients calculated in the seven wells for which burial history curves were plotted (table 11) ranged from 1.7 to $2.3^{\circ} \mathrm{F} / 100 \mathrm{ft}\left(31.0\right.$ to $\left.41.9^{\circ} \mathrm{C} / \mathrm{km}\right)$ after correction for nonequilibration of borehole temperatures (Deford and others, 1976). With one exception, the wells used to calculate geothermal gradient had several logging runs each, and the highest bottom-hole temperature was used to calculate geothermal gradient. Temperatures in the wells did not appear to be approaching thermal equilibrium in the period of time that had elapsed since circulation (up to about 30 hours), so the correction factor was applied to the calculated geothermal gradients. The average gradient calculated for the seven wells, $2.1^{\circ} \mathrm{F} / 100 \mathrm{ft}\left(38.3^{\circ} \mathrm{C} / \mathrm{km}\right)$, was used as the present-day geothermal gradient in the study area. This value is higher than the geothermal gradient of 1.7 to $1.8^{\circ} \mathrm{F} / 100 \mathrm{ft}\left(31.0\right.$ to $\left.32.8^{\circ} \mathrm{C} / \mathrm{km}\right)$ shown for this area on a map of geothermal gradients for North America (Deford and others, 1976). The wells used to make the map may not have each had several logging runs, and thus the bottom hole tempertures that were used may have been further from equilibrium than the temperatures in the seven wells used for this study. A geothermal gradient map by Schoeppel and Gilarranz (1966) shows values of 1.9 to $2.1^{\circ} \mathrm{F} / 100 \mathrm{ft}\left(34.6\right.$ to $\left.38.3^{\circ} \mathrm{C} / \mathrm{km}\right)$ in the study area. Finally, using a geothermal gradient of $2.1^{\circ} \mathrm{F} / 100 \mathrm{ft}\left(38.3^{\circ} \mathrm{C} / \mathrm{km}\right)$ gives calculated thermal 
Table 11. Calculated time-temperature indices (TTI) and corresponding vitrinite reflectance $\left(R_{0}\right)$ values for three horizons.

\begin{tabular}{|c|c|c|c|c|c|c|}
\hline 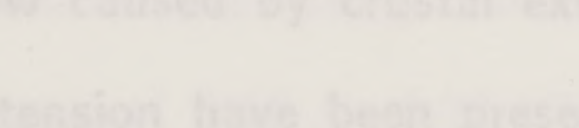 & Travis & Peak & $\begin{array}{r}\mathrm{T} \\
\text { Cotton } \\
\end{array}$ & Valley & $\begin{array}{r}T \\
\text { Bos }\end{array}$ & ier \\
\hline Well & TTI & $R_{0}$ & TTI & $R_{0}$ & TTI & $R_{0}$ \\
\hline Arkla Scott No. 5 & 37 & 0.8 & 172 & 1.3 & 581 & 1.8 \\
\hline Sun D. O. Caudle No. 2 & 42 & 0.9 & 197 & 1.4 & 669 & 1.9 \\
\hline $\begin{array}{l}\text { Clayton Williams } \\
\text { Sam Hughes No. } 1\end{array}$ & 80 & 1.0 & 372 & 1.6 & 903 & 2.0 \\
\hline Amoco Kangerga No. C-1 & 93 & 1.1 & 419 & 1.7 & 1400 & 2.2 \\
\hline Prairie Mast No. A-1 & 166 & 1.3 & 1121 & 2.1 & 2279 & 2.4 \\
\hline ARCO Phillips No. 1 & 200 & 1.4 & 857 & 2.0 & 3414 & 2.6 \\
\hline Ashland S.F.O.T. No. 1 & 552 & 1.8 & 3509 & 2.7 & 6611 & 3.1 \\
\hline
\end{tabular}


maturities in close agreement with measured values of vitrinite reflectance (see section on Time-Temperature Index).

The geothermal gradient in the southern part of the study area was probably higher in the past than it is now because of increased heat flow related to rifting of the Gulf of Mexico. The expected increase in heat flow caused by crustal extension and the rate of heat-flow decline after extension have been presented for a model of crustal extension (heat flow extension model) by Royden and others (1980). The amount of heat-flow elevation above a normal base level and the rate at which the elevated heat flow declines depend on the amount of stretching of the continental lithosphere (Royden and others, 1980). The study area is far enough from the actual rifting that probably only in the southern part. in Nacogdoches County, was there sufficient crustal stretching to cause significant elevation in heat flow. In the area of the Ashland S.F.O.T No. 1 well, crustal stretching has a gamma value of 0.31 (Dunbar and Sawyer, in preparation), where gamma $=1$ corresponds to pure oceanic crust and gamma $=0$ represents undisturbed continental crust (Royden and others, 1980). Heat flow in this area was probably elevated to about 1.2 heat flow units at the time of rifting, and declined to the normal level of 1.0 heat flow units by 80 million years after rifting (Royden and others, 1980). The rifting in the Gulf of Mexico took place at approximately 180 mya. about the time of the Early-Middle Jurassic boundary (Buffler and Sawyer. 1985), so the elevated heat flow had probably completely declined to the present value of 1.0 heat flow units by 100 mya. The location of the 
Prairie Mast No. 1-A well experienced less stretching. with a gamma value of about 0.26 (Dunbar and Sawyer, in preparation). Heat flow in this area was probably elevated to only about 1.07 heat flow units at the time of rifting, and it had probably completely declined to 1.0 heat flow units by 100 mya. All the other wells in the study area are located far enough north of the rifting that the small amount of crustal stretching [gamma values of 0.16 to 0.22 (Dunbar and Sawyer, in preparation)] caused only negligible increase in heat flow. and that increase had largely decaying by 150 mya, before deposition of the Bossier shale.

To try to estimate paleogeothermal gradients from the estimates of elevated heat flow due to crustal stretching, it is necessary to estimate the thermal conductivity of the sedimentary section. The thermal conductivity was calculated from the following relation:

Heat flow $=($ Thermal conductivity $)(\Delta$ temperature $) /(\Delta$ depth $)$.

using the present geothermal gradient of $2.1^{\circ} \mathrm{F} / 100 \mathrm{ft}\left(38.3^{\circ} \mathrm{C} / \mathrm{km}\right)$ and the present heat flow of $1.0 \mathrm{cal} \mathrm{cm}^{-2} \mathrm{sec}^{-1}$ (Royden and others, 1980). A value for thermal conductivity of $2.6 \times 10^{-3} \mathrm{cal} \mathrm{cm}^{-1} \mathrm{sec}^{-1}{ }^{\circ} \mathrm{C}^{-1}$ was calculated from these data. This value is lower than what would be expected from a mostly lithified sedimentary sequence. Values of thermal conductivity typically range from $4 \times 10^{-3}$ for unlithified sediment to $7.5 \times$ $10^{-3} \mathrm{cal} \mathrm{cm}^{-1} \mathrm{sec}^{-1}{ }^{\circ} \mathrm{C}^{-1}$ for continental lithosphere (Royden and others. 1980). The low value calculated for the study area indicates that heat is 
being distributed by fluid convection as well as conduction, and the calculated thermal conductivity reflects both of these processes (D. Sawyer. personal communication, 1986). In the past, it is likely that convective distribution of heat was at least as important as it is today. Therefore. in the calculations of paleogeothermal gradient, the value $2.6 \times 10^{-3} \mathrm{cal}$ $\mathrm{cm}^{-1} \mathrm{sec}^{-1}{ }^{\circ} \mathrm{C}^{-1}$ was used for thermal conductivity.

For the five wells in the northern part of the study area for which burial history curves were plotted (fig. 1, table 11), there is no justification for using a paleogeothermal gradient higher than the present gradient. The small amount of crustal stretching associated with rifting did not result in elevated heat flow, and there is no other reason to believe heat flow was higher in this area in the past than it is now. However, for the two wells in Nacogdoches County, higher paleogeothermal gradients were calculated based on the elevated heat flows predicted by the crustalextension model of Royden and others (1980). The Ashland well had a calculated geothermal gradient of $2.4^{\circ} \mathrm{F} / 100 \mathrm{ft}\left(43.8^{\circ} \mathrm{C} / \mathrm{km}\right)$ at 150 mya (30 my after rifting), and a gradient of $2.3^{\circ} \mathrm{F} / 100 \mathrm{ft}\left(41.9^{\circ} \mathrm{C} / \mathrm{km}\right)$ at 130 mya (50 my after rifting). These elevated gradients were included on the burial history curve for the Ashland S.F.O.T. No. 1 well (fig. 39A) using a linear decline in geothermal gradient between calculated points. The present geothermal gradient of $2.1^{\circ} \mathrm{F} / 100 \mathrm{ft}\left(38.3^{\circ} \mathrm{C} / \mathrm{km}\right)$ was assumed to be in place since 100 mya ( 80 my after rifting) based on the model of Royden and others (1980). Similarly, the paleogeothermal gradient for the Prairie Mast No. 1-A was calculated to have been $2.26^{\circ} \mathrm{F} / 100 \mathrm{ft}$ 
$\left(41.2^{\circ} \mathrm{C} / \mathrm{km}\right)$ at 150 mya and $2.2^{\circ} \mathrm{F} / 100 \mathrm{ft}\left(40.1^{\circ} \mathrm{C} / \mathrm{km}\right)$ at 130 mya. The geothermal gradient had declined to its present value of $2.1^{\circ} \mathrm{F} / 100 \mathrm{ft}$ $\left(38.3^{\circ} \mathrm{C} / \mathrm{km}\right)$ by 100 mya. Isotemperature lines were added to the burial history curves at $10^{\circ} \mathrm{C}$ intervals, so that the temperature of a given horizon on the curve can be determined for any time throughout its burial history (isotemperature lines are shown only every $20^{\circ} \mathrm{C}$ in fig. 39).

\section{Time-Temperature Index}

A check on the thermal maturity of organic matter determined by vitrinite reflectance and pyrolysis can be obtained by calculating the timetemperature index (TTI) of that horizon. This method, which was originally proposed by Lopatin (1971) and subsequently modified by Waples (1980). involves reconstruction of the burial and temperature history of a deposit. The maturity of a given horizon is assumed to depend on time and temperature, and Lopatin assumed maturation reaction rates doubled with every $10^{\circ} \mathrm{C}$ temperature rise. By plotting burial depth versus time and using the estimated paleogeothermal gradient, it is possible to determine how long a given horizon remained within each $10^{\circ} \mathrm{C}$ temperature interval (fig. 39). TTI can then be calculated by the following formula:

$$
T T I=\Sigma\left(\Delta T_{n}\right)\left(r^{n}\right)
$$


where the $n$-values are the highest and lowest temperature intervals encountered by the horizon, $r^{n}$ is a temperature factor for the given temperature interval, and $\Delta T_{n}$ is the time spent in a given temperature interval in millions of years (Waples, 1980).

Waples empirically tested the hypothesis of doubling every $10^{\circ} \mathrm{C}$ by calculating TTI for samples of early Paleozoic to Quaternary age from all over the world using Lopatin's method and comparing the resulting TTI to measured $R_{0}$ values (Waples, 1980). There was significant scatter in the data, which Waples attributed to errors in $R_{0}$ measurements and errors in the burial-history curves that were used. However, he concluded that the average line relating $T T I$ and $R_{0}$ provided a satisfactory method to estimate thermal maturity from burial-history information (Waples, 1980). The empirical relationship between $R_{0}$ and TTI indicates that a TTI of 15 corresponds to the onset of oil generation $\left(R_{0}=0.65 \%\right)$, and a TTI of 75 corresponds to the zone of peak oil generation $\left(R_{0}=1.0 \%\right)$. The end of oil generation occurs at a TTI value of $160\left(R_{0}=1.3 \%\right)$. and the upper limit for preservation of oil with API gravity $<40$ occurs at a TTI of about $500\left(R_{0}=1.75 \%\right)$.

The empirical relationship between TTI and $R_{0}$ (Waples, 1980) has been used in this study to compare calculated TTI values for the top of the Travis Peak horizon (table 11) to measured $R_{0}$ values in the Travis Peak (table 6). In this way, it is possible to test the burial history curves and estimated paleogeothermal gradients by determining if the TTI values that are calculated using these models provide an estimate of $R_{0}$ 
that is reasonably close to the measured values. TTI values were also calculated for the top of the Cotton Valley and Bossier Formations: no measured $R_{0}$ values were available from these units, so the calculated TTI values provide an estimate of the thermal maturity of these horizons through time (table 11).

The $R_{0}$ values for the top of the Travis Peak estimated from TTI calculations range from a low of $0.8 \%$ in the Arkla Scott No. 5 (TTI = 37) to a high value of $1.8 \%$ in the Ashland S.F.O.T. No. $1(\mathrm{TTI}=552)$ (table 11). The calculated $R_{0}$ values are quite close to the measured values in three of the wells for which measured $R_{0}$ data were available. The measured $R_{0}$ values in samples from the Clayton Williams Sam Hughes No. 1 range from $1.1 \%$ to $1.2 \%$, and the calculated $R_{0}$ is $1.0 \%$ (table 11). In the Prairie Mast No. 1-A well, the measured $R_{0}$ is $1.3 \%$ to $1.4 \%$, and the calculated $R_{0}$ is $1.3 \%$ (table 11). Finally, in the Ashland S.F.O.T. well, the measured $R_{0}$ is $1.8 \%$ to $1.86 \%$, and the calculated $R_{0}$ is $1.8 \%$ (table 11 ). Considering the many assumptions that go into TTI calculations, the agreement in these three wells is excellent and provides supporting evidence that the burial history curves and inferred paleogeothermal gradients are reasonable.

In two of the wells, the calculated $R_{o}$ values were not as close to the measured values. In the Sun D. O. Caudle No. 2 well (fig. 39B), the measured $R_{0}$ of $1.06 \%$ is somewhat higher than the calculated value of $0.9 \%$. This difference suggests that either the top of the Travis Peak was actually buried deeper than the burial-history model indicates (fig. 39), or 
the geothermal gradient was higher, or both. The Sun D. O. Caudle No. 2 well is located near the top of the Sabine Uplift structure, so it is possible that there was more uplift and erosion in this area than the burial history curve indicates (fig. 39B).

In the ARCO B. F. Phillips No. 1 well, the measured $R_{0}$ value of $1.0 \%$ is lower than the calculated value of $1.39 \%$ (table 11). Vitrinite reflectance measurements from the top of the Travis Peak in two other wells in Chapel Hill field near the ARCO Phillips No. 1 have similar $R_{0}$ values of $1.09 \%$ and $1.1 \%$ (table 6 ). For this well, the difference between measured and calculated $R_{0}$ values suggests that either the top of the Travis Peak in the ARCO Phillips No. 1 well was not buried as deep as the burial-history curve indicates or the geothermal gradient was lower, or both. One possible source of the difference is the assumption that 1.500 $\mathrm{ft}(450 \mathrm{~m})$ of Wilcox and younger sediment were removed in this area since the end of the middle Eocene. The ARCO Phillips No. 1 well is not very close to the coal mines with the surface vitrinite reflectance values which were used to infer $1.500 \mathrm{ft}(450 \mathrm{~m})$ of Tertiary erosion; if less deposition and subsequent erosion took place compared to the burial-history model, it would explain the difference between measured and calculated $R_{0}$ values. Changes in the recent end of the burial-history curve have a large effect on the calculated $R_{0}$ values because the stratigraphic horizon of interest remains at high temperatures for long time periods (fig. 39). For example, if only $500 \mathrm{ft}(150 \mathrm{~m})$ of Wilcox and younger sediment were deposited and then eroded, not $1,500 \mathrm{ft}(450 \mathrm{~m})$, the calculated $R_{0}$ for the 
top of the Travis Peak would be $1.2 \%$, which is in closer agreement to the measured $R_{0}$ values in the Chapel Hill field.

The generally good agreement between calculated and measured $R_{0}$ values suggests that the models for burial history and paleotemperature that were used in this study give a reasonable approximation to the actual burial history of the top of the Travis Peak. Therefore, it can be assumed that the models give similarly good approximations for the base of the Travis Peak (top of the Cotton Valley) and the top of the Bossier shale. Calculated $R_{0}$ values for the base of the Travis Peak range from $1.3 \%$ in the Arkla Scott No. $5(\mathrm{TTI}=172)$ to $2.7 \%$ in the Ashland S.F.O.T. No. 1 (TTI = 3.508) (table 11). These calculated $R_{0}$ values suggest that in all seven wells, the Cotton Valley Formation has reached maturity levels equivalent to the end of the oil-generation zone (TTI of 160: $R_{0}$ of $1.3 \%$ ). In the most mature well, the Ashland S.F.O.T. No. 1. the top of the Cotton Valley Formation has passed the limit for the occurrence of wet gas (TTI of 1.500; $R_{0}$ of 2.0).

The calculated $R_{0}$ values for the Bossier shale range from $1.8 \%$ in the Arkla Scott No. $5(\mathrm{TTI}=581)$ to $3.1 \%$ in the Ashland S.F.O.T. No. $1(\mathrm{TTI}=6.611)$ (table 11). The Bossier shale, therefore, has passed completely through the oil-generation zone in all of the wells that were modeled (table 11). The approximate time when the Bossier shale reached the onset of oil generation (at a TTI of 15) and the time when it reached peak oil generation (at a TTI of 75) can be determined from the burialhistory curves. The calculated times at which the Bossier shale reached a 
TTI of 15 in the seven wells all cluster between 94 and 97 mya (fig. 34). Similarly, the top of the Bossier shale reached peak oil generation between 58 and 68 mybp (fig. 39). The time at which oil was expelled from the Bossier shale and the time at which the oil began to enter the reservoirs in the Travis Peak are not known. However, assuming the Bossier shale was the source rock for Travis Peak oil, the oil could not have entered the Travis Peak before about 95 mya, and the oil is more likely to have entered the reservoirs at about 65 mya (fig. 39). when the Bossier shale had reached peak oil generation. 


\section{INTERPRETATION OF DIAGENETIC HISTORY}

The paragenetic sequence of authigenic phases in Travis Peak sandstones was determined primarily from petrographic relations. The relative order of occurrence of the major phases was as follows: 1) illite rims, 2) dolomite, 3) quartz overgrowths, 4) feldspar dissolution and albitization, 5) illite, chlorite, and ankerite cement, and 6) introduction of reservoir bitumen. Minor authigenic phases include calcite, kaolinite, barite, and anhydrite. The conditions under which each of the cements precipitated can be inferred from petrographic and geochemical evidence and from burial-history information.

\section{Illite Rims}

In most Travis Peak sandstone samples, detrital grains are covered by a thin rim of tangentially oriented illite. The illite in these rims is interpreted to be authigenic, and it was the earliest phase to precipitate in most sandstones. These tangentially oriented illite rims may have recrystallized from clay cutans that entered the sandstone shortly after deposition and coated detrital grains. The precipitation (or recrystallization) of the illite rims occurred before quartz cementation, and therefore probably formed in the shallow subsurface, from 0 to $2,000 \mathrm{ft}$ ( 0 to $600 \mathrm{~m})$ 
(fig. 40). In most sandstones, the authigenic illite rims were thin and probably discontinuous, and quartz cement precipitated over them. Seen in thin section. the illite rims form a thin, birefringent 'dust rim' between detrital quartz grains and quartz overgrowths. On a few grains, most notably in the Arkla Scott No. 5 core, the illite was sufficiently thick to prevent later nucleation of quartz cement except in small areas where there evidently were breaks in the rims. The presence of illite cutans had an important influence on the subsequent diagenesis of the deep Arkla Scott No. 5 sandstones. Nucleation of later cements, particularly quartz, was evidently inhibited by the illite cutans, and these samples retain anomalously high porosity and permeability at $1.560 \mathrm{ft}(475 \mathrm{~m})$ below the top of the Travis Peak (figs 32, 35).

\section{Calcite Cement}

Calcite cement is rare in Travis Peak sandstones. Nodules in Travis Peak sandstones and mudstones consist of microsparry dolomite and ankerite but may have originally formed as pedogenic calcite (cf. McBride and others, in preparation; Pettijohn, 1975). Sparry calcite occurs in fossiliferous sandstones interbedded with limestones near the top of the formation, and it precipitated early in the burial history of the sandstones. Where it occurs, it is the first cement around detrital grains, and those sandstones display loose packing, suggesting little compaction had occurred before calcite precipitation. The calcite cement probably formed in a 


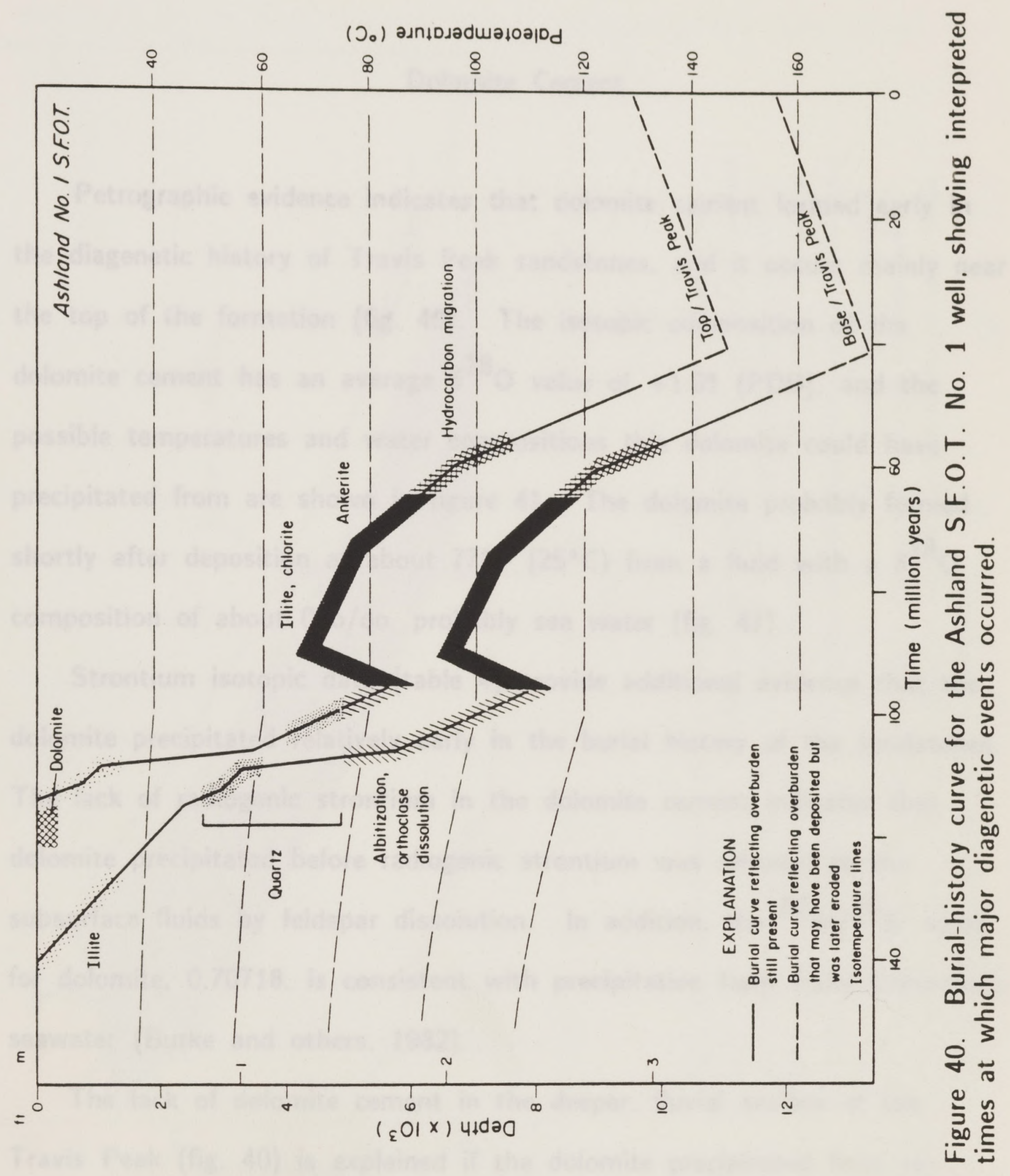


meteoric phreatic environment, and aragonitic fossil fragments in the sandstones probably provided the source of $\mathrm{CaCO}_{3}$ in the cement.

\section{Dolomite Cement}

Petrographic evidence indicates that dolomite cement formed early in the diagenetic history of Travis Peak sandstones, and it occurs mainly near the top of the formation (fig. 40). The isotopic composition of the dolomite cement has an average $\delta^{18} \mathrm{O}$ value of +1.01 (PDB), and the possible temperatures and water compositions this dolomite could have precipitated from are shown in figure 41 . The dolomite probably formed shortly after deposition at about $77^{\circ} \mathrm{F}\left(25^{\circ} \mathrm{C}\right)$ from a fluid with a $\delta^{18} \mathrm{O}$ composition of about 0 \%/oo, probably sea water (fig. 41).

Strontium isotopic data (table 4) provide additional evidence that the dolomite precipitated relatively early in the burial history of the sandstones. The lack of radiogenic strontium in the dolomite cement indicates that dolomite precipitated before radiogenic strontium was released to the subsurface fluids by feldspar dissolution. In addition, the ${ }^{87} \mathrm{Sr} /{ }^{86} \mathrm{Sr}$ value for dolomite, 0.70718 , is consistent with precipitation from Early Cretaceous seawater (Burke and others, 1982).

The lack of dolomite cement in the deeper, fluvial section of the Travis Peak (fig. 40) is explained if the dolomite precipitated from sea water because the deeper Travis Peak sediments were exposed to meteoric water early in their burial history. Only the sediments deposited in the 


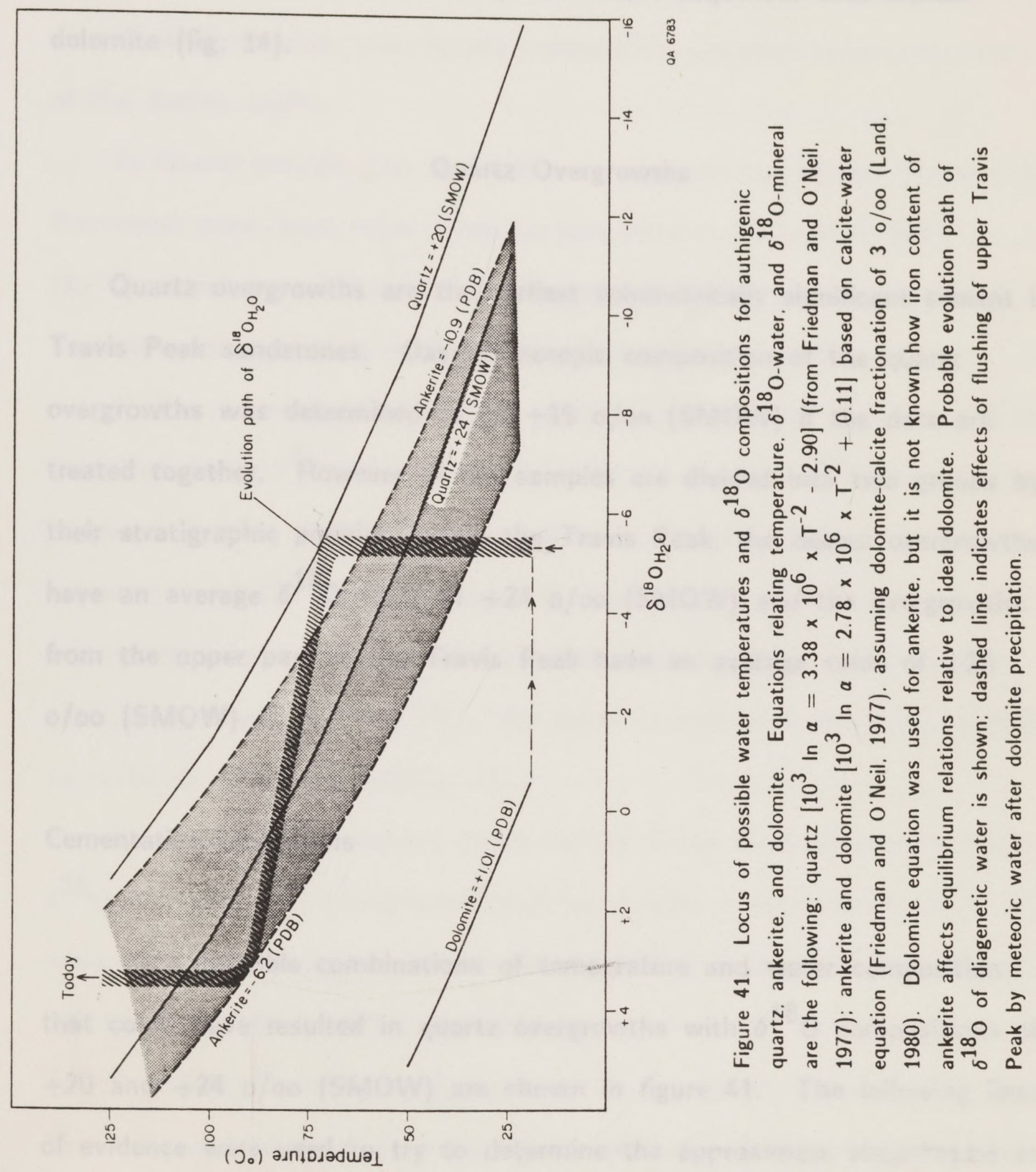


delta-fringe system at the top of the Travis Peak contained brackish to marine water at the time of deposition. Consequently, only samples from the upper Travis Peak show complete cement sequences that include dolomite (fig. 14).

Quartz Overgrowths

Quartz overgrowths are the earliest volumetrically significant cement in Travis Peak sandstones. Oxygen isotopic composition of the quartz overgrowths was determined to be +19 o/oo (SMOW) if the data are treated together. However, if the samples are divided into two groups by their stratigraphic position within the Travis Peak, the deeper overgrowths have an average $\delta^{18} \mathrm{O}$ value of $+24 \% / 00$ (SMOW) and the overgrowths from the upper part of the Travis Peak have an average value of +20 o/oo (SMOW).

\section{Cementation Conditions}

The possible combinations of temperature and water composition that could have resulted in quartz overgrowths with $\delta^{18} \mathrm{O}$ compositions of +20 and $+24 \mathrm{o} / 00(\mathrm{SMOW})$ are shown in figure 41 . The following lines of evidence were used to try to determine the approximate temperature and $\delta^{18} \mathrm{O}$ composition of the water that precipitated the quartz cement: 
1) Albitization of plagioclase and dissolution of orthoclase took place before movement of the Sabine Uplift, as will be discussed in more detail in the section on feldspars. Quartz cementation preceeded albitization and orthoclase dissolution. thus quartz cementation occurred before movement of the Sabine Uplift.

2) Quartz precipitation in sandstones near the top of the Travis Peak Formation must have taken place at temperatures lower than $185^{\circ} \mathrm{F}$ $\left(85^{\circ} \mathrm{C}\right)$. which was the maximum temperature at the top of the Travis Peak immediately before movement on the Sabine Uplift (fig. 39).

3) The water that precipitated quartz cement in the upper part of the formation (with $\delta^{18} \mathrm{O}$ of $+20 \% / 00$ ) would have had a $\delta^{18} \mathrm{O}$ composition of about -3 o/oo (SMOW) if it precipitated at the maximum possible temperature of $185^{\circ} \mathrm{F}\left(85^{\circ} \mathrm{C}\right)$ (fig. 41). Because the quartz cement must have precipitated at a somewhat lower temperature than $185^{\circ} \mathrm{F}\left(85^{\circ} \mathrm{C}\right)$. such as at about $167^{\circ} \mathrm{F}\left(75^{\circ} \mathrm{C}\right)$, the water composition was probably closer to -4 to -5 o/oo (SMOW)(fig. 41).

4) If the quartz cement deeper in the Travis Peak Formation (with $\delta^{18} \mathrm{O}$ of $\left.+24 \mathrm{o} / \mathrm{oo}\right)$ precipitated from water with a composition of -4 to -5 o/oo, the deeper cement probably precipitated at a temperature of about 122 to $140^{\circ} \mathrm{F}\left(55\right.$ to $\left.65^{\circ} \mathrm{C}\right)$ (fig. 41$)$.

Therefore, for the reasons listed above, the quartz cement in the Travis Peak is interpreted as having precipitated from hot meteoric water. Assuming the meteoric water had a composition of $-5 \% / 00$. which is the value of shallow ground water in East Texas today (Kreitler and Dutton. 
1983). the quartz overgrowths in the older, deeper part of the Travis Peak precipitated at a temperature of about $131^{\circ} \mathrm{F}\left(55^{\circ} \mathrm{C}\right)$ and the overgrowths in the younger, shallower part precipitated at a temperature of about $167^{\circ} \mathrm{F}$ $\left(75^{\circ} \mathrm{C}\right.$ ) (figs. 40, 41). Water compositions that would be necessary to precipitate these overgrowths at lower temperatures [for example, -10.7 $\circ / 00$ at $\left.77^{\circ} \mathrm{F}\left(25^{\circ} \mathrm{C}\right)\right]$ are not realistic values for coastal recharge. Quartz cement in Jurassic Norphlet sandstones in Mississippi and Alabama has also been interpreted as the product of deeply circulating, hot meteoric water (McBride and others, in preparation).

\section{Paleohydrology}

Meteoric water in the Gulf Coast today extends to depths as great as $5.000 \mathrm{ft}(1.5 \mathrm{~km})$ along the fluvial axes of the Catahoula Formation (Galloway, 1984). In the Wilcox Formation in the central Texas Gulf Coast, water as depleted as $-2 \% / 00$ extends to the top of geopressure. almost $10,000 \mathrm{ft}(3 \mathrm{~km})$ deep (Fisher, 1982). The paleogeographic setting of the East Texas area in the Early Cretaceous should have permitted equally deep meteoric circulation. Travis Peak sandstones to the northwest (updip) of the study area were interpreted as fan-delta deposits (McGowen and Harris, 1984), implying that areas of topographic relief fringed East Texas at this time. The Ouachita. Arbuckle, and Wichita Mountains may have remained exposed even after marine progradation covered the Travis Peak deposits with Sligo and later carbonates and could have continued as 
a recharge zone for a regional meteoric flow system.

The meteoric water that precipitated quartz overgrowths in the Travis Peak was probably part of an ascending limb of a regional ground-water circulation system. Quartz solubility increases with increasing temperature, so there would be no reason for quartz to precipitate from descending meteoric water. Instead, the meteoric water probably circulated to deeper, hotter zones and became saturated with respect to quartz, then precipitated quartz cement later as it rose, cooled, and became oversaturated. Large volumes of water must have circulated through Travis Peak sandstones in order to precipitate the observed volume of quartz overgrowths. An estimate of the volume of water necessary to precipitate the observed volume of quartz cement can be calculated as follows (Land and Dutton. 1978). Assuming the fluid cooled from 212 to $167^{\circ} \mathrm{F}\left(100^{\circ} \mathrm{C}\right.$ to $\left.75^{\circ} \mathrm{C}\right)$ as it rose, the saturation with respect to quartz decreased from $65 \mathrm{ppm}$ to 36 ppm (Siever, 1962). Thus, approximately $29 \mathrm{ppm} \mathrm{SiO}_{2}$ could precipitate from each liter of fluid. Assuming that each $\mathrm{cm}^{3}$ of Travis Peak sandstone is $15 \%$ authigenic quartz, each $\mathrm{cm}^{3}$ contains about $400 \mathrm{mg}$ $\mathrm{SiO}_{2}$ that precipitated from solution (density $=2.65 \mathrm{~g} / \mathrm{cm}^{3}$ ). Therefore. approximately $13.8 ।\left(13.800 \mathrm{~cm}^{3}\right)$ of water were needed to cement each $\mathrm{cm}^{3}$ of sandstone. If $1 / 8$ of the silica in quartz overgrowths was derived from pressure solution along stylolites, the volume of water needed to supply the rest of the silica would have been somewhat less, approximately 12 I. 
The hydrologic conditions that would allow such large volumes of meteoric water to circulate to these depths and temperatures are not known. The water that precipitated the quartz cement evidently had not interacted significantly with the rocks it had passed through because its interpreted $\delta^{18} \mathrm{O}$ composition was unchanged from the expected composition of meteoric water. Free convection of meteoric water, caused by an elevated geothermal gradient in this recently-rifted area, may have been operating in the thick pile of Upper Jurassic and Lower Cretaceous sandstone. Extensive dissolution of salt domes and formation of cap rock during the Cretaceous (Kreitler and Dutton, 1983) provide additional evidence that large volumes of fluids were moving through the sedimentary section at this time.

The evidence that sandstones deeper in the formation were cemented by quartz at lower temperatures than sandstones near the top of the Travis Peak suggests that cementation started in the deeper sandstones. This would occur if the cementing fluids were ascending and entering the formation from below. Cementation in the sandstones near the top of the formation began after more time had passed, and the section was buried deeper and was therefore hotter.

\section{Variations in Quartz Cementation}

Some sandstones in the delta-fringe facies near the top of the Travis Peak retain higher porosity and permeability than do most sandstones in 
the formation. The higher total porosity in these zones is caused by both higher primary and secondary porosity: more primary porosity remains in these zones because they are less extensively cemented by quartz cement than are most Travis Peak sandstones. The explanation for the less extensive quartz cement in parts of the delta-fringe system may be the lack of aquifer continuity. In the deeper, sand-rich fluvial-deltaic section. there is good continuity between laterally and vertically juxtaposed braidedstream sandstones. Consequently, the transmissivity of this section was high. Sandstones in the delta-fringe system are encased in lowpermeability mudstones, so transmissivity was lower than transmissivity of the fluvial-deltaic system. Therefore, the volume of fluid flow probably was greater in the fluvial-deltaic system than in the relatively less permeable delta-fringe system, which resulted in more uniform and extensive quartz cementation in the fluvial-deltaic sandstones compared with quartz cementation in the delta-fringe sandstones. Thus, sandstones in what originally was the most transmissive part of the Travis Peak now have low permeability because of extensive quartz cementation, whereas some sandstones in the mud-rich upper Travis Peak retain higher primary porosity because of the lower volumes of fluid flow and poor aquifer continuity in the delta-fringe system.

Quartz cementation may have ended when the Travis Peak was buried deeper than meteoric water was able to circulate and discharge. Alternatively, the deeply-circulating meteoric flow system may have been disrupted for reasons that are not known. Movement on the Sabine Uplift 
may have changed regional ground-water circulation patterns, but quartz cementation had probably ended by the time this movement occurred.

\section{Feldspar Albitization and Dissolution}

The following trends with depth below the top of the Travis Peak have been noted in the feldspars: 1) An abrupt loss of unaltered orthoclase occurs at $1.200 \mathrm{ft}(365 \mathrm{~m})$ below the top of the formation (fig. 11). Above that depth many samples lack orthoclase but other samples retain up to $3 \%$ orthoclase. 2) Albitization increases with depth below the top of the Travis Peak (fig. 10). These trends do not occur with present, absolute depth below sea level, but only with depth below the top of the formation. Therefore, the trends must have already been in place before movement of the Sabine Uplift. Before uplift occurred, absolute depth and depth below the top of the Travis Peak were equivalent. After movement on the Sabine Uplift this was no longer true: the part of the study area nearest the structure experienced more uplift and erosion than did the parts of the study area that were farther away.

\section{Orthoclase Dissolution}

The loss of orthoclase in the deeper part of the Travis Peak may have been controlled by temperature. Before movement on the Sabine Uplift, the horizon at $1.200 \mathrm{ft}(365 \mathrm{~m})$ below the top of the Travis Peak 
had reached a temperature of about $203^{\circ} \mathrm{F}\left(95^{\circ} \mathrm{C}\right)$ in all parts of the study area, whereas the top of the formation had only reached about $176^{\circ} \mathrm{F}$ $\left(80^{\circ} \mathrm{C}\right.$ ) (figs. 39, 40). There may have been a critical temperature below which complete orthoclase alteration and dissolution did not take place, and that temperature apparently was about $203^{\circ} \mathrm{F}\left(95^{\circ} \mathrm{C}\right)$. Only the deepest parts of the Travis Peak reached the temperature necessary to dissolve all orthoclase. Similarly abrupt loss of orthoclase with depth is observed both in the Wilcox (Fisher and Land, 1986) and Frio (Land and Milliken, 1981: Land, 1984) Formations in the Tertiary section of the Gulf Coast. Other explanations for the abrupt loss of orthoclase at $1.200 \mathrm{ft}$ (365 $\mathrm{m}$ ) below the top of the formation seem less likely than temperature control. No known change in depositional environment or sandstone interconnectedness occurs at this depth. There is no evidence that different water chemistry developed above and below this depth.

\section{Albitization}

Similarly, albitization is essentially complete in the lower part of the Travis Peak, where temperatures were highest before movement of the Sabine Uplift (figs. 39, 40), and less complete in the upper part of the formation. The gradual increase in albitization with depth in the formation suggests that no threshold temperature existed for albitization to occur. Instead, increased temperature resulted in more complete albitization. Albitization probably started in the lower part of the Travis Peak, after 
quartz cementation had ended (fig. 40), at a temperature of about $176^{\circ} \mathrm{F}$ $\left(80^{\circ} \mathrm{C}\right)$. Albitization in the upper part of the formation probably started somewhat later, when that part of the Travis Peak reached $176^{\circ} \mathrm{F}\left(80^{\circ} \mathrm{C}\right)$ (figs. 39, 40). Albitization in the Frio Formation was estimated to have begun at temperatures of 122 to $185^{\circ} \mathrm{F}\left(50\right.$ to $85^{\circ} \mathrm{C}$ ) (Kaiser, 1984).

The fluids responsible for albitization were most likely $\mathrm{Na}-\mathrm{Cl}$ brines that were generated during the Early Cretaceous by salt dome dissolution (Kreitler and others, 1983). The albitization process resulted in the release of $\mathrm{Ca}$ into the brine and incorporation of $\mathrm{Na}$ into feldspars, thus modifying the original brine toward the $\mathrm{Na}-\mathrm{Ca}-\mathrm{Cl}$ brine that occurs in the Travis Peak now (table 5).

\section{Feldspar Distribution}

Superimposed on the general trend of increasing albitization with depth (fig. 10) and the abrupt loss of orthoclase at $1.200 \mathrm{ft}(365 \mathrm{~m})$ below the top of the Travis Peak (fig. 11) is the wide range of feldspar content and composition within the uppermost part of the formation. Orthoclase is absent in all but one sample from the top $50 \mathrm{ft}(15 \mathrm{~m})$ of the formation (fig. 11). Albitization is also extensive in a few samples near the top of the formation (fig. 10). The loss of orthoclase from the top of the Travis Peak may have occurred at a later time than the loss of orthoclase deeper in the formation, possibly after movement on the Sabine Uplift. Most of the hydrocarbon production in the Travis Peak is from the upper few 
hundred feet of the formation, and later fluid movement that emplaced the hydrocarbons in sandstones at the top of the formation may have also caused the dissolution of orthoclase. More complete albitization also may have resulted from the movement of hydrocarbon-transporting fluids at the very top of the formation.

The main phases of albitization of plagioclase and dissolution of orthoclase occurred after quartz cementation. Permeability in most Travis Peak sandstones was reduced considerably by extensive quartz cement. particularly in the lower part of the formation. Nevertheless, sufficient volumes of fluid must have continued to move through the sandstones after quartz cementation to allow the feldspar reactions to occur. McBride and others (in preparation) believe that fluid movement in a well-cemented sandstone occurs in capillary pores between grains and cements. The presence of early illite rims around detrital grains may have enhanced the ability of fluid to move between grains and cements.

\section{Development of Secondary Porosity}

The main phase of secondary porosity development occurred as a result of feldspar dissolution before movement on the Sabine Uplift. Secondary porosity is most abundant in the upper part of the Travis Peak and decreases with depth in the formation (fig. 31). This is the same trend observed for orthoclase dissolution and albitization, not the inverse trend which might be expected. Possible explanations for the decrease in 
secondary porosity with depth below the top of the Travis Peak are as follows. The greatest volume of secondary porosity occurs in the same part of the formation that retained the highest volume of primary porosity (fig. 30) after quartz cementation. Once quartz cementation reduced permeability in the lower, fluvial-deltaic part of the formation, the upper delta-fringe facies probably had relatively higher transmissivity. Greater volumes of fluid movement in this part of the Travis Peak could have resulted in more extensive development of secondary porosity.

If greater transmissivity in the delta-fringe section were the only factor operating, one would expect to observe less feldspar at the top of the formation and more feldspar preserved at depth. The opposite is observed. however: more plagioclase and orthoclase occur at the top of the formation. One possible explanation is that the amount of detrital feldspar increased upsection in the Travis Peak. The upper part of the formation now contains more feldspar because it started with more, but it also contains more secondary porosity because there was more feldspar to dissolve.

Alternatively, detrital feldspar content may have been essentially uniform throughout the formation, but early flow of meteoric fluids dissolved many of the feldspar grains in the lower part of the section. If early feldspar dissolution occurred before quartz cementation, compaction would have destroyed the secondary pores that were created. When the later phase of feldspar dissolution and albitization occurred after quartz cementation. less feldspar remained in the lower part of the formation and 
less secondary porosity was created.

Formation of secondary porosity requires acid, and the most commonly suggested source is $\mathrm{CO}_{2}$ or carboxylic acid generated by decarboxylation of kerogen (Schmidt and McDonald, 1979; Surdam and others, 1984). The organic matter that is present in the Travis Peak is mainly Type III kerogen, which is relatively oxygen-rich and would yield more $\mathrm{CO}_{2}$ and carboxylic acid than other types of kerogen. However, because the Travis Peak is a sand-rich formation and those shales it does contain are mostly organic-poor, it does not seem likely that all the $\mathrm{CO}_{2}$ necessary to account for the secondary porosity in Travis Peak sandstones could have been generated in the interbedded Travis Peak shales. Additional $\mathrm{CO}_{2}$ may have been derived from deeper formations such as the Bossier.

Most oxygen is lost from kerogen by the time a vitrinite reflectance of $0.5 \%$ is reached (Lundegard and others, 1984), which is before oil generation begins. Using the burial history curves to calculate TTI. and hence $R_{0}$, kerogen in the Bossier shale probably reached an $R_{0}$ of $0.5 \%$ at about 104 mya and kerogen at the top of the Travis Peak reached an $R_{0}$ of $0.5 \%$ at about 99 mya (fig. 40). Feldspar dissolution is interpreted to have occurred from about 96 to 107 mya (fig. 40). Thus, the release of some $\mathrm{CO}_{2}$ by decarboxylation of kerogen occurred at approximately the same time as feldspar dissolution. suggesting at least some of the secondary porosity in Travis Peak sandstones was generated by this mechanism. The small amount of feldspar removed from the Travis Peak, as compared to the Frio Formation, does not present a severe acid-balance 
problem, as is true in the Frio (Lundegard and others, 1984).

\section{Authigenic Clays}

Authigenic clays, mostly illite and chlorite, occur within many of the secondary pores in Travis Peak sandstones, including pores that still contain remnants of partially dissolved feldspars. The clays are interpreted to be reaction products of feldspar dissolution. Precipitation of illite and chlorite must have been somewhat later than feldspar dissolution because they occur inside the secondary pores created by feldspar dissolution, but there probably was considerable overlap in the timing of feldspar dissolution and authigenic clay precipitation.

The relationship among authigenic clays is not clear. Kaolinite is rare in Travis Peak sandstones except in two wells, the Amoco Kangerga No. C-1 and the Arkla Scott No. 5. Petrographic evidence indicates it formed mainly after quartz, although there may have been some overlap in the precipitation of kaolinite and quartz. The relative timing of kaolinite cement precipitation supports the idea that it is a reaction product of feldspar dissolution in an acid environment. Kaolinite may have formed only in these two wells, or it may have been more common in all wells but has since reacted to form illite or chlorite in all but the Kangerga and Scott wells. The reason for the precipitation or preservation of kaolinite only in these particular wells is not known. However, both occurrences are in samples from deep in the fluvial section. 
Illite and chlorite commonly occur within the same secondary pores. and it is not possible in the SEM or petrographic microscope to determine the relative order of their formation. Potassium in illite could have been derived from orthoclase dissolution. Iron in the iron-rich chlorite may have been derived from transformation of smectite to illite in adjacent mudstones, but there is no evidence to support this hypothesis. Instead, the iron may have been derived from thermal reduction of iron compounds (Woronick and Land, 1985). Redbeds are abundant in the entire Travis Peak Formation, even in the delta-fringe facies, so there would have been an abundant source of iron for thermal reduction. Illite may have been the most common clay to form initially after feldspar dissolution, with chlorite either precipitating later when reduced iron became abundant or forming by alteration of the previously precipitated illite in the presence of abundant iron.

\section{Ankerite}

Ankerite was the last volumetrically important cement to precipitate. It fills primary and secondary pores and replaces framework grains. including quartz. The inclusion of radiogenic strontium in ankerite indicates it precipitated after feldspar dissolution and albitization. Petrographic evidence suggests that ankerite in part replaces earlier dolomite cement and in part occurs as zoned overgrowths on the dolomite. Carbon isotopic values are depleted with respect to marine carbonate, suggesting the 
ankerite contains some carbon derived from thermal oxidation of organic matter. Most of the carbon, however, was derived from recycled marine carbon. probably from the dolomite cement. The iron in the ankerite, like the iron in the chlorite cement, probably was a product of thermal reduction of ferric iron in shales. Iron content increases in the outer zones of the ankerite. suggesting that iron content of the pore fluids increased during ankerite precipitation. In iron-rich fluids, ankerite is more stable than dolomite or calcite, even in fluids with a high $\mathrm{Ca} / \mathrm{Mg}$ ratio (Carpenter, 1985), so calcium-rich ankerite replaced dolomite. Thus, most of the material in the ankerite cement was probably derived from the older dolomite cement, with only ferrous iron, some depleted ${ }^{13} \mathrm{C}$, and radiogenic strontium added into the system.

The distribution of ankerite within the Travis Peak (fig. 24). concentrated in the upper, delta-fringe facies, is explained if the source of most of the material in the ankerite was the dolomite. Cement sequences in the upper Travis Peak are more likely to include both dolomite and ankerite compared with sequences in the lower Travis Peak, which commonly contain only quartz and authigenic clays (fig. 14).

The $\delta^{18} \mathrm{O}$ content of ankerite varies from -6.2 o/oo to -10.9 o/oo (PDB). The possible temperatures and water compositions that could have resulted in ankerite with this range of $\delta^{18} \mathrm{O}$ values are shown in figure 41. Precipitation of ankerite preceeded migration of hydrocarbons into the Travis Peak, which is interpreted as having begun about 65 mya, as will be discussed in the section on hydrocarbon migration. Therefore, ankerite 
near the top of the formation must have precipitated at a temperature lower than $194^{\circ} \mathrm{F}\left(90^{\circ} \mathrm{C}\right.$ ) (figs. 39, 40). The lowest temperature at which ankerite could have precipitated, assuming it formed after feldspar dissolution had ended, was about $158^{\circ} \mathrm{F}\left(70^{\circ} \mathrm{C}\right)$ (figs. 39, 40).

One possible interpretation of these data is that ankerite precipitation began at about $167^{\circ} \mathrm{F}\left(75^{\circ} \mathrm{C}\right)$ from a water of $\delta^{18} \mathrm{O}$ composition of -3 to -4 (SMOW): the resulting ankerite would have a $\delta^{18} \mathrm{O}$ composition of -11 o/oo (PDB) (fig. 41). This water would have essentially the same $\delta^{18} \mathrm{O}$ composition as the water that precipitated quartz cement. Ankerite precipitation continued as the water temperature gradually increased to about $194^{\circ} \mathrm{F}\left(90^{\circ} \mathrm{C}\right)$ and the composition evolved to a $\delta^{18} \mathrm{O}$ composition of +3 o/oo (SMOW). The last ankerite to precipitate would have a composition of $-6 \% / 00$ (PDB). A similar explanation for the range of ankerite composition in the Norphlet Formation, that the composition of the water evolved from about -2 to +3 o/oo (SMOW) but stayed relatively constant in temperature, was suggested by McBride and others (in preparation) for the Norphlet Formation. Evolution of the Travis Peak water from -4 to +3 could be explained if meteoric water circulation ended, and fluids in the formation gradually evolved as they were replaced by basinal, shale-buffered fluids. The fluids that precipitated the later ankerite cements are similar to present-day fluids in the Travis Peak, which have $\delta^{18} \mathrm{O}$ compositions ranging from +1 to +3 \% $/ 00$ (SMOW)(table 5).

The hypothesis presented above is not the only one that could explain the observed range of $\delta^{18} \mathrm{O}$ values in Travis Peak ankerite. However, if 
the assumptions about the temperatures at which the ankerite precipitated are correct, the range of $\delta^{18} \mathrm{O}$ values in the ankerite could not have formed from a water with fixed $\delta^{18} \mathrm{O}$ composition that simply increased in temperature. For example, the ankerite could not have formed from a water of $-4 \mathrm{o} / \mathrm{oo}(\mathrm{SMOW})$ that increased in temperature from $45^{\circ} \mathrm{C}$ to $70^{\circ} \mathrm{C}$ (fig. 41), because ankerite precipitation occurred at temperatures greater than $70^{\circ} \mathrm{C}$. Because of the constraints on the temperature at which ankerite precipitated, it is difficult to devise a scenario by which the ankerite with composition -6 o/oo formed before the ankerite of composition -11 o/oo (SMOW).

\section{Hydrocarbon Migration}

Timing of migration of oil into Travis Peak reservoirs can be estimated from burial-history curves of the Bossier shale (fig. 39). The Bossier reached the beginning of oil generation at about 95 mya and peak oil generation at about 65 mya (fig. 39). The time at which oil began to migrate out of the source rocks is not known. One factor that controls how soon primary migration occurs is the organic richness of the source rock (Tissot and Welte, 1978), but no values of TOC for Bossier shales are available. For this study, the assumption was made that oil had migrated out of the Bossier shale and reached Travis Peak reservoirs by the time peak oil generation occurred in the source rocks at 65 mya. Migration probably occurred as a separate oil phase, and microfacturing of 
the source rocks allowed the oil to move through the low-permeability source beds (Tissot and Welte, 1978). Once the oil reached the overlying Cotton Valley and Travis Peak sandstones, it probably migrated through remaining primary and secondary pores and through natural fractures. Movement on the Sabine Uplift may have induced natural fractures in Travis Peak sandstones that had by then been extensively cemented by quartz.

All of the authigenic minerals in Travis Peak reservoirs are interpreted to have precipitated before oil entered the sandstones. The precipitation of reservoir bitumen from liquid oil in the Travis Peak must have occurred later than 65 mya, but because the source of the gas that caused the deasphalting is not known, the timing is not well constrained. If the gas was generated in place from thermal alteration of Travis Peak oil. it may have began forming at approximately 40 mya. At 40 mya, the top of the Travis Peak reached a TTI of 120 , the approximate maturity level at which peak dry gas generation occurs, in the Ashland S.F.O.T. No. 1 well (fig. 39). Alternatively, if the gas that caused deasphalting came from the Bossier shale, it may have migrated into Travis Peak reservoirs as early as about 57 mya. At 57 mya, the Bossier shale reached the maturation level associated with peak dry gas generation $(\mathrm{TTI}=120)$.

Minor additional feldspar dissolution apparently occurred after the introduction of reservoir bitumen because some sandstones with abundant reservoir bitumen have open secondary pores. Reservoir bitumen is otherwise so pervasive in these samples that it seems unlikely any 
secondary pores that existed at the time of deasphalting would not have been filled.

\section{Comparison with Diagenesis in Other Gulf Coast Mesozoic and Tertiary Sandstones}

The diagenetic history of Travis Peak sandstones is broadly similar to diagenesis of other Mesozoic and Cenozoic sandstones in the Gulf Coast. Precipitation of early clay rims, followed by quartz overgrowths, and finally late-stage ankerite and illite or chlorite is the same basic sequence that occurred in Jurassic Norphlet (McBride and others, in preparation). Cretaceous Tuscaloosa (Suchecki, 1983), and Eocene Wilcox (Boles and Franks, 1979; Fisher and Land, 1986; Loucks and others, 1986) sandstones. Tertiary sandstones younger than Eocene have undergone similar cementation except that they lack ankerite cement (Loucks and others. 1984 and 1986). Albitization of plagioclase and dissolution of orthocase have been reported in Eocene Wilcox, Oligocene Frio. Miocene, and PlioPleistocene sandstones of the Gulf Coast (e.g. Boles, 1982: Gold, 1984: Land, 1984: and Milliken, 1985; and Fisher and Land, 1986). Plagioclase in Norphlet sandstones has been albitized, but orthoclase evidently did not dissolve because of the presence of $\mathrm{K}$-rich brines derived from adjacent evaporites (McBride and others, in preparation). 
Although diagenesis of Travis Peak sandstones is generally similar to diagenesis of these other units, there are important differences as well. Precipitation from hot, deeply circulating meteoric water has been inferred for cements in Gulf Coast Mesozoic sandstones (Suchecki, 1983: McBride and others, in preparation; this study), but not for Tertiary formations. McBride and others have suggested that hydrologic systems involving deeply circulating meteoric water may be characteristic of recently rifted basins as a result of elevated heat flow. The increased temperatures may have caused increased volumes of fluid flow by adding thermal density differences to the normal gravitational head of the system.

The volume of quartz cement in Travis Peak sandstones confirms that large volumes of fluids must have passed through them. The average of $17 \%$ quartz cement in well-sorted Travis Peak sandstones is higher than the volume of quartz cement reported in most Gulf Coast sandstones, even in Mesozoic sandstones. Good aquifer connectedness in most of the Travis Peak section may have resulted in increased flow in this part of the sedimentary pile.

The end of quartz cementation by meteoric fluids and the inferred evolution of subsurface fluids to heavier $\delta^{18} \mathrm{O}$ compositions (McBride and others, in preparation; this study) may have coincided with the decay of elevated heat flow due to rifting approximately 100 mya. Thus, perhaps the regional meteoric flow system that was in place during the Mesozoic no longer existed in the Tertiary, resulting in diagenesis by different types 
of fluids. Quartz cement is volumetrically much less important in Tertiary sandstones [mean of $4.6 \%$ in Wilcox sandstones (Fisher and Land, 1986) and $2.6 \%$ in Frio sandstones (Land, 1984)]. possibly because less active hydrologic systems existed at that time compared with the Mesozoic. 


\section{CONCLUSIONS}

Combining petrographic, geochemical, and stratigraphic information, the following conclusions can be drawn about diagenesis of Lower Cretaceous Travis Peak sandstones in East Texas.

1. The major diagenetic reactions in Travis Peak sandstones occurred during Cretaceous time. Only thermal maturation of oil, formation of reservoir bitumen, and minor feldspar dissolution continued into the Tertiary.

2. Much of the diagenesis took place in hot, meteoric fluids. Quartz cement, volumetrically the most important authigenic phase in the Travis Peak, precipitated from water with a $\delta^{18} \mathrm{O}$ composition of near $-5 \% / 00$ (SMOW) at temperatures that ranged from about 131 to $167^{\circ} \mathrm{F}\left(55^{\circ} \mathrm{C}\right.$ to $75^{\circ} \mathrm{C}$ ), at depths from 3.000 to $5.000 \mathrm{ft}(900$ to $1.500 \mathrm{~m})$.

3. Plagioclase albitization and orthoclase dissolution probably occurred before movement of the Sabine Uplift at about 96 mya because both types of feldspar exhibit trends with depth below the top of the Travis Peak but not with absolute depth. Unaltered orthoclase does not occur more than $1.200 \mathrm{ft}(370 \mathrm{~m})$ below the top of the formation. Albitization of plagioclase is more complete deeper in the formation.

4. Porosity and permeability are most abundant in the upper Travis Peak and decrease with depth in the formation. Primary porosity has been 
preserved in some sandstones at the top of the formation because less fluid moved through the poorly connected sandstones in the delta-fringe facies. Good sandstone continuity in the deeper, fluvial section allowed greater fluid volumes to pass through this part of the formation initially. which resulted in extensive quartz cementation and loss of primary porosity. Greater secondary porosity at the top of the formation indicates more feldspars were dissolved and the resulting secondary pores were preserved compared with deeper in the Travis Peak.

5. Illite and chlorite are common in secondary pores and are the products of feldspar dissolution. Chlorite probably formed later than illite. and it incorporated ferrous iron generated by thermal reduction of iron compounds in Travis Peak red shales.

6. Ankerite also incorporates ferrous iron from shales. Iron content increases toward the outside of ankerite crystals, indicating iron in the pore fluids increased during precipitation. Ankerite was derived primarily from early dolomite cement, which was unstable in the late-stage, iron-rich pore fluids with high $\mathrm{Ca} / \mathrm{Mg}$ ratio. Some light carbon from maturation of organic matter and radiogenic strontium were incorporated into the ankerite.

7. The range of $\delta^{18} \mathrm{O}$ compositions of ankerite cement $(-10.9$ to -6.2 o/oo PDB) indicates the pore fluids evolved during the time ankerite formed. The earliest ankerite evidently precipitated from meteoric fluids with $\delta^{18} \mathrm{O}$ values of -3 to $-4 \% / 00$ (SMOW). The later ankerite precipitated from fluids with $\delta^{18} \mathrm{O}$ composition of +2 to $+3 \%$ oo 
(SMOW), which is the composition of present-day Travis Peak water (Kreitler and others, 1983).

8. Oil in the Travis Peak could not have been generated in the shales interbedded with Travis Peak reservoirs because those shales are organicpoor and contain mainly vitrinite. The source rocks for Travis Peak oil are postulated to be shales of the Bossier Formation. Oil entered Travis Peak reservoirs about 65 mya; at a later time, gas went into solution in the oil, causing deasphalting of the heavy molecules in the oil. Most hydrocarbons in the Travis Peak occur in the upper part of the formation. where more porosity remained after cementation. Migration of oil into the Travis Peak ended cementation.

9. Diagenetic events in the Travis Peak are similar to those described in other Mesozoic sandstones of the Gulf Coast, particularly with respect to the importance of hot. meteoric water in the diagenetic history. As suggested by McBride and others (in preparation). deeply circulating meteoric water may be characteristic of early diagenesis in recently rifted basins. 


\section{REFERENCES}

Boles, J. R.. 1982. Active albitization of plagioclase, Gulf Coast Tertiary: American Journal of Science, v. 282, p. 165-180.

Boles, J. R., and Franks, S. G., 1979. Clay diagenesis in Wilcox sandstones of southwest Texas: implications of smectite diagenesis on sandstone cementation: Journal of Sedimentary Petrology. V. 49, p. 55-70.

Braunstein. J., Huddleston. P.. McLemore, W.. and Biel. R.. in press. Gulf Coast Province Regional Correlation Chart: American Association of Petroleum Geologists Correlation Chart Series.

Bray. E. E., and Evans, E. D., 1961. Distribution of n-paraffins as a clue to recognition of source beds: Geochimica et Cosmochimica Acta, v. 22. p. 2-15.

Brewer, R., 1964, Fabric and minerals analysis of soils: New York. Wiley. $470 \mathrm{p}$.

Buffler, R. T., and Sawyer. D. S.. 1985. Distribution of crust and early history. Gulf of Mexico basin: Gulf Coast Association of Geological Societies Transactions, v. 35, p. 333-344.

Burke, W. H., Denison, R. E., Hetherington, E. A., Koepnick, R. B., Nelson, H. F., and Otto, J. B., 1982, Variations of seawater ${ }^{87} \mathrm{Sr} /{ }^{86} \mathrm{Sr}$ throughout Phanerozoic time: Geology, v. 10. p. 516-519.

Carpenter. A. B.. 1985. Effect of ferrous iron on the stability and nucleation of dolomite. in Timing of siliciclastic diagenesis: relationship to hydrocarbon migration: Sixth Annual Research Conference Gulf Coast Section Society of Economic Paleontologists and Mineralogists. p. 4-5.

Clayton. R. N.. and Mayeda, T. K., 1963. The use of bromine pentafluoride in the extraction of oxygen from oxides and silicates for isotopic analysis: Geochimica et Cosmochimica Acta, v. 27, p. 43-52.

Collins, S. E.. 1980. Jurassic Cotton Valley and Smackover reservoir trends. East Texas, north Louisiana and south Arkansas: American Association of Petroleum Geologists Bulletin. v. 64, no. 7. p. 10041013. 
David K. Davies and Associates. Inc., 1984a. Fluid sensitivity evaluation. Travis Peak sand zones. Sam Hughes No. 1 well, Panola County. Texas: Kingwood. Texas, report prepared for Petrophysical Services. Inc., $50 \mathrm{p}$.

David K. Davies and Associates, Inc., 1984b. Sensitivity evaluation of the 8.188 to 8.394 .9 foot Travis Peak interval. ARCO B. F. Phillips No. 1 well, Smith County. Texas: Kingwood. Texas, report prepared for Petrophysical Services, Inc.. 60 p.

David K. Davies and Associates. Inc.. 1985a. Fluid sensitivity evaluation. three Travis Peak sand zones. Ashland S.F.O.T. No. 1 well. Nacogdoches County. Texas: Kingwood. Texas, report prepared for Petrophysical Services, Inc., 52 p.

David K. Davies and Associates, Inc., 1985b. Fluid sensitivity evaluation. three Travis Peak sand zones. Prairie Producing Mast No. A-1 well. Nacogdoches County. Texas: Kingwood. Texas, report prepared for Petrophysical Services, Inc.. 64 p.

Deford, R. K., Kehle, R. O.. and Connolly, E. T., 1976. Geothermal gradient map of North America: American Association of Petroleum Geologists and The United States Geologic Survey.

Dow. W. G., 1978. Petroleum source beds on continental slopes and rises: American Association of Petroleum Geologists Bulletin, v. 62, no. 9. p. $1584-1606$.

Dunbar. J., and Sawyer, D. S. in preparation. Implications of continental crust extension for plate reconstruction: An example from the Gulf of Mexico.

Dutton. S. P.. 1986. Petrography and diagenesis of Lower Cretaceous Travis Peak (Hosston) Formation. East Texas: Gulf Coast Association of Geological Societies Transactions, v. 36, p. 73-81.

Dutton, S. P.. and Finley, R. J., 1986. Depositional and diagenetic controls on reservoir quality in tight sandstones of the Travis Peak (Hosston) Formation. East Texas: Proceedings, 1986 Society of Petroleum Engineers/U.S. Department of Energy/Gas Research Institute Joiont Symposium on Unconventional Gas Technology, Louisville. Kentucky. SPE Paper No. 15220. p. 153-162.

Fisher, R. S., and Land, L. S., 1986. Diagenetic history of Eocene Wilcox sandstones, South-Central Texas: Geochimica et Cosmochimica Acta, v. 50, p. $551-561$. 
Fisher, R. S., 1982, Diagenetic history of Eocene Wilcox sandstones and associated formation waters. South-Central Texas: The University of Texas at Austin. Ph.D. dissertation, 185 p.

Folk, R. L., 1974. Petrology of sedimentary rocks: Austin. Texas, Hemphill, 182 p.

Fracasso, M. A., Finley, R. J., and Dutton, S. P., 1986, Subregional stratigraphic relations, diagenesis, and reservoir quality of tight gas sandstones. Sabine Uplift area. Texas: Society of Petroleum Engineers. East Texas regional meeting. SPE 14666, p. 133-142.

Friedman. I., and O'Neil. J. R., 1977, Data of geochemistry, sixth edition. Chapter KK. Compilation of stable isotopic fractionation factors of geochemical interest: U. S. Geological Survey Professional Paper $440 \mathrm{~K}$.

Galloway. W. E., 1984, Hydrogeologic regimes of sandstone diagenesis, in McDonald, D. A., and Surdam. R. C.. eds., Clastic diagenesis:

American Association of Petroleum Geologists Memoir 37, p. 3-13.

Galloway, W. E., Ewing. T. E., Garrett. C. M., Tyler. N., and Bebout. D. G., 1984. Atlas of major Texas oil reservoirs: The University of Texas at Austin. Bureau of Economic Geology, 139 p.

Gold. P. B., 1984. Diagenesis of Middle and Upper Miocene sandstones, Louisiana Gulf Coast: The University of Texas at Austin. Master's thesis, $115 \mathrm{p}$.

Halbouty, M. T., and Halbouty. J. J., 1982. Relationships between East Texas Field region and Sabine Uplift in Texas: American Association of Petroleum Geologists Bulletin, v. 66, no. 8, p. 1042-1054.

Heald, M. T., 1955. Stylolites in sandstones: Journal of Geology, v. 63. p. 101-114.

Hunt, J. M., 1979, Petroleum geochemistry and geology: San Francisco. W. H. Freeman and Co., $617 \mathrm{p}$.

Jackson. M. P. A., 1981. Tectonic environment during early infilling of the East Texas Basin. in Kreitler, C. W.. and others, Geology and geohydrology of the East Texas Basin. a report on the progress of nuclear waste isolation feasibility studies (1980): The University of Texas at Austin. Bureau of Economic Geology Geological Circular 81-7. p. 7-11. 
Jonas. E. C., and McBride, E. F., 1977. Diagenesis of sandstone and shale: application to exploration for hydrocarbons: The University of Texas at Austin. Department of Geological Sciences Continuing Education Publication No. 1, 120 p.

Kaiser, W. R., 1984. Predicting reservoir quality and diagenetic history in the Frio Formation (Oligocene) of Texas, in McDonald, D. A., and Surdam, R. C.. eds.. Clastic diagenesis: American Association of Petroleum Geologists Memoir 37. p. 195-215.

Koons, C. B., Bond. J. G., and Peirce, F. L., 1974. Effects of depositional environment and postdepositional history on chemical composition of Lower Tuscaloosa oils: American Association of Petroleum Geologists Bulletin, v. 58, no. 7, p. $1272-1280$.

Kreitler. C. W., and Dutton, S. P., 1983, Origin and diagenesis of cap rock. Gyp Hill and Oakwood salt domes. Texas: The University of Texas at Austin. Bureau of Economic Geology Report of Investigations No. 131. 58 p.

Kreitler, C. W., Collins, E. W.. Fogg, G. E., Jackson, M. P. A., and Seni, S. J., 1983. Hydrogeologic characterization of the saline aquifers. East Texas Basin--implications to nuclear waste storage in East Texas salt domes: The University of Texas at Austin. Bureau of Economic Geology, draft report prepared for U. S. Department of Energy under Contract No. DE-AC97-80ET46617, 54 p.

Land, L. S., 1980. The isotopic and trace element geochemistry of dolomite: the state of the art: Society of Economic Paleontologists and Mineralogists Special Publication. No. 28, p. 87-110.

Land, L. S., 1984. Frio sandstone diagenesis. Texas Gulf Coast: a regional isotopic study, in McDonald. D. A., and Surdam. R. C., eds., Clastic diagenesis: American Association of Petroleum Geologists Memoir 37. p. 37-62.

Land, L. S., and Dutton. S. P.. 1978, Cementation of a Pennsylvanian deltaic sandstone: isotopic data: Journal of Sedimentary Petrology, v. 48, no. 4. p. $1167-1176$.

Land, L. S., and Milliken. K. L., 1981. Feldspar diagenesis in the Frio Formation. Brazoria County. Texas Gulf Coast: Geology, v. 9, p. 314318.

Lopatin. N. V., 1971. Temperature and geologic time as factors of carbonification (in Russian): Akad. Nauk SSSR Izv. Ser. Geol., no. 3. p. 95-106. 
Loucks, R. G., Dodge, M. M.. and Galloway. W. E.. 1984. Regional controls on diagenesis and reservoir quality in Lower Tertiary sandstones along the Texas Gulf Coast. in McDonald. D. A., and Surdam. R. C.. eds.. Clastic diagenesis: American Association of Petroleum Geologists Memoir 37. p. 37-62.

Loucks, R. G., Dodge. M. M., and Galloway, W. E., 1986, Controls on porosity and permeability of hydrocarbon reservoirs in lower Tertiary sandstones along the Texas Gulf Coast: The University of Texas at Austin. Bureau of Economic Geology Report of Investigations No. 149. $78 \mathrm{p}$.

Lundegard. P. D.. Land. L. S., and Galloway. W. E., 1984. Problem of secondary porosity: Frio Formation (Oligocene), Texas Gulf Coast: Geology, v. 12, no. 7. p. 399-402.

McBride, E. F.. Land. L. S., and Mack. L. E., in preparation, Diagenesis of Norphlet Formation (Upper Jurassic). Mississippi and Alabama.

McCrea, J. M.. 1950. The isotopic chemistry of carbonates and a paleotemperature scale: Journal of Chemistry and Physics, v. 18, p. 849-857.

McGowen. M. K., and Harris. D. W.. 1984. Cotton Valley (Upper Jurassic) and Hosston (Lower Cretaceous) depositional systems and their influence on salt tectonics in the East Texas Basin. in Ventress. W. P. S., Bebout, D. G., Perkins, B. P., and Moore, C. 'H., eds., The Jurassic of the Gulf Rim: Proceedings of the Third Annual Research Conference, Gulf Coast Section Society of Economic Paleontologists and Mineralogists, p. 213-249.

Milliken. K. L., 1985. Petrology and burial diagenesis of Plio-Pleistocene sediments, northern Gulf of Mexico: The University of Texas at Austin. Ph.D. dissertation, $112 \mathrm{p}$.

Milliken, K. L.. Land, L. S., and Loucks, R. G.. 1981. History of burial diagenesis determined from isotopic geochemistry. Frio Formation. Brazoria County. Texas: American Association of Petroleum Geologists Bulletin, v. 65, no. 8, p. 1397-1413.

Milner, C. W. D., 1982, Geochemical analyses of sedimentary organic matter and interpretation of maturation and source potential, in How to assess maturation and paleotemperatures: Society of Ecoñomic Paleontologists and Mineralogists Short Course 7. p. 217-252. 
Molenaar. N.. 1986. The interrelation between clay infiltration. quartz cementation, and compaction in Lower Givetian terrestrial sandstones, Northern Ardennes. Belgium: Journal of Sedimentary Petrology, v. 56. no. 3. p. 359-369.

Pettijohn, F. J., 1975. Sedimentary rocks: New York. Harper and Row. $628 \mathrm{p}$.

Prezbindowski, D. R., 1985, Burial cementation--is it important? A case study. Stuart City trend. South Central Texas: Society of Economic Paleontologists and Mineralogists Special Publication. No. 36, p. 241264.

Ramseyer, K., 1982, A new cathodoluminescence microscope and its application to sandstone diagenesis: International Congress on Sedimentology. McMaster University, Hamilton. Ontario, p. 120.

Rogers, M. A., McAlary, J. D., and Bailey, N. J. L., 1974, Significance of reservoir bitumens to thermal-maturation studies, western Canada Basin: American Association of Petroleum Geologists Bulletin, v. 58. no. 9. p. $1806-1824$.

Royden, L., Sclater, J. G., and Von Herzen, R. P., 1980, Continental margin subsidence and heat flow: Important parameters in formation of petroleum hydrocarbons: American Association of Petroleum Geologists Bulletin, v. 64 , no. 2, p. 173-187.

Sassen. R., Moore, C. H., and Meendsen, F. C., 1986a. Concentration of source rock organic matter during carbonate diagenesis. Jurassic Smackover Formation: American Association of Petroleum Geologists Bulletin. v. 70, no. 5, p. 644 .

Sassen, R., Nunn, J. A., Moore. C. H., Meendsen, F. C., and Iliff, V. K., 1986b. Models for hydrocarbon generation and destruction. Eastern Jurassic Smackover Formation: American Association of Petroleum Geologists Bulletin. v. 70, no. 5. p. 644.

Saucier, A. E., 1985, Geologic framework of the Travis Peak (Hosston) Formation of East Texas and North Louisiana, in Finley, R. J.. Dutton, S. P.. Lin. Z. S., and Saucier, A. E., The Travis Peak (Hosston) Formation: geologic framework, core studies, and engineering field analysis: The University of Texas at Austin. Bureau of Economic Geology. topical report prepared for Gas Research Institute under contract no. 5082-211-0708, p. 3-74. 
Saucier. A. E., Finley, R. J., and Dutton. S.P.. 1985. The Travis Peak (Hosston) Formation of East Texas and North Louisiana: Proceedings, 1985 Society of Petroleum Engineers/Department of Energy Joint Symposium on Low Permeability Reservoirs, Denver, Colorado. SPE/DOE Paper No. 13850, p. 15-22.

Schmidt, V., and McDonald, D. A., 1979. The role of secondary porosity in the course of sandstone diagenesis: Society of Economic Paleontologists and Mineralogists Special Publication. No. 26, p.175207.

Schoeppel, D. J., and Gilarranz. S., 1966. Use of well log temperatures to evaluate regional geothermal gradients: Journal of Petroleum Technology, v. 237, p. 667-673.

Seni, S. J., 1983. Travis Peak Formation, East Texas, in Finley, R. J., and others. Geologic analysis of primary and secondary tight gas sand objectives. Phase A--Selective investigations of six stratigraphic units; Phase B--Initial studies: The University of Texas at Austin. Bureau of Economic Geology, annual report prepared for the Gas Research Institute under contract no. 5082-211-0708, p. 175-188.

Seni. S. J., and Jackson. M. P. A., 1983. Evolution of salt structures. East Texas Diapir Province. Part 1: Sedimentary record of halokinesis: American Association of Petroleum Geologists Bulletin, v. 67, no. 8. p. 1219-1244.

Siever, R., 1962. Silica solubility, $0-200^{\circ} \mathrm{C}$, and the diagenesis of siliceous sediments: Journal of Geology, v. 70, p. 127-150.

Sofer Z., 1984. Stable carbon isotope compositions of crude oils: application to source depositional environments and petroleum alteration: American Association of Petroleum Geologists Bulletin, v. 68. no. 1. p. 31-49.

Stewart, S. K., 1984. Smackover and Haynesville facies relationships in north-central East Texas, in Presley. M. W.. ed.. The Jurassic of East Texas: East Texas Geological Society, p. 56-62.

Suchecki, R. W.. 1983, Isotopic evidence for large-scale interaction between formation waters and clastic rocks: Geological Society of America Abstracts with Programs, v. 15, no. 6, p. 701.

Surdam. R. C., Boese, S. W., and Crossey, L. J., 1984. The chemistry of secondary porosity, in McDonald, D. A., and Surdam, R. C.. eds., Clastic diagenesis: Āmerican Association of Petroleum Geologists Memoir 37, p. 127-149. 
Syers, J. K., Chapman. S. L., Jackson. M. L., and Rex, R. W., 1968. Quartz isolation from rocks, sediments and soils for determination of oxygen isotopic composition: Geochimica et Cosmochimica Acta, v. 32. p. $1022-1025$.

Tissot, B. P.. 1984, Recent advances in petroleum geochemistry, applied to hydrocarbon exploration: American Association of Petroleum Geologists Bulletin, v. 68 , no. 5, p. 545-563.

Tissot. B. P., and Welte. D. H., 1978, Petroleum formation and occurrence: New York. Springer-Verlag, 538 p.

Waples, D. W.. 1980. Time and temperature in petroleum formation: Application of Lopatin's method to petroleum exploration: American Association of Petroleum Geologists Bulletin, v. 64, no. 6, p. 916-926.

Wood, D. H., and Guevara. E. H., 1981. Structural cross sections and general stratigraphy. East Texas Basin: The University of Texas at Austin. Bureau of Economic Geology Cross Sections, 21 p.

Woronick. R. E., and Land, L. S., 1985, Late burial diagenesis, Lower Cretaceous Pearsall and Lower Glen Rose Formations. South Texas: Society of Economic Paleontologists and Mineralogists Special Publication No. 36, p. 265-275. 
The vita has been removed from the digitized version of this document. 